


\section{Onderbouwing locaties en additionele maatregelen ten behoeve van Natuurbeleid Gelderland}

Verweij, P.J.F.M., J.Y. Frissel, R. Jochem \& R. Pouwels

Dit onderzoek is uitgevoerd door Wageningen Environmental Research (Alterra) in opdracht van en gefinancierd door de provincie Gelderland.

Wageningen Environmental Research

Wageningen, oktober 2017

Rapport 2847

ISSN 1566-7197 
Verweij, P.J.F.M., J.Y. Frissel, R. Jochem \& R. Pouwels, 2017. Onderbouwing locaties en additionele maatregelen ten behoeve van Natuurbeleid Gelderland. Wageningen, Wageningen Environmental Research, Rapport 2847. 78 blz.; 51 fig.; 4 tab.; 53 ref.

Ten behoeve van het opstellen van nieuw natuurbeleid heeft de provincie Gelderland behoefte aan inzicht waar en welke additionele maatregelen nodig zijn om verdroging, verzuring, vermesting en versnippering tegen te gaan voor het vergroten van de biodiversiteit van de Vogel- en Habitatrichtlijn in Gelderland. In twee workshops is de kennis van de deskundigen uit de provincie en haar netwerk gecombineerd met modelresultaten uit de lerende evaluatie. De discussies uit beide expertmeetings hebben geresulteerd in het aanwijzen van 22 gebieden/regio's waarvoor is aangegeven uit welke ecosystemen het gebied bestaat en welke drukfactoren opgelost moeten worden in het gebied voor de verdere realisatie van de biodiversiteitsdoelstellingen. De deskundigen geven aan dat in deze gebieden/regio's naast grote opgaven ook grote kansen liggen in het landbouwgebied. Naast natuurinclusieve landbouw liggen er ook kansen voor verbetering van natuur en biodiversiteit vanuit gezondheid en klimaatadaptatie.

Trefwoorden: Lerende Evaluatie Natuurpact, Vogel- en Habitatrichtlijn, Model for Nature Policy (MNP), QUICKScan, Biodiversiteitsdoelen

Dit rapport is gratis te downloaden van https://doi.org/10.18174/425923 of op www.wur.nl/environmental-research (ga naar 'Wageningen Environmental Research' in de grijze balk onderaan). Wageningen Environmental Research verstrekt geen gedrukte exemplaren van rapporten.

(9) 2017 Wageningen Environmental Research (instituut binnen de rechtspersoon Stichting Wageningen Research), Postbus 47, 6700 AA Wageningen, T 03174807 00, E info.alterra@wur.nl, www.wur.nl/environmental-research. Wageningen Environmental Research is onderdeel van Wageningen University \& Research.

- Overname, verveelvoudiging of openbaarmaking van deze uitgave is toegestaan mits met duidelijke bronvermelding.

- Overname, verveelvoudiging of openbaarmaking is niet toegestaan voor commerciële doeleinden en/of geldelijk gewin.

- Overname, verveelvoudiging of openbaarmaking is niet toegestaan voor die gedeelten van deze uitgave waarvan duidelijk is dat de auteursrechten liggen bij derden en/of zijn voorbehouden.

Wageningen Environmental Research aanvaardt geen aansprakelijkheid voor eventuele schade voortvloeiend uit het gebruik van de resultaten van dit onderzoek of de toepassing van de adviezen.

Wageningen Environmental Research Rapport 2847 | ISSN 1566-7197

Foto omslag: Gebieden in Gelderland waar biodiversiteitswinst te realiseren is 


\section{Inhoud}

$\begin{array}{ll}\text { Samenvatting } & 5\end{array}$

1

$\begin{array}{ll}\text { Inleiding } & 7\end{array}$

$\begin{array}{lll}1.1 & \text { Achtergrond } & 7\end{array}$

$\begin{array}{lll}1.2 & \text { Projectdoelstelling } & 7\end{array}$

$\begin{array}{lll}1.3 & \text { Leeswijzer } & 7\end{array}$

$\begin{array}{ll}\text { Expertmeetings } & 8\end{array}$

$\begin{array}{ll}\text { Gebruikte gegevens en tools } & 9\end{array}$

3.1 MNP 4.0 in a nutshell 9

3.1.1 Bepalen kwaliteit leefgebied 10

3.1.2 Bepalen duurzaam voorkomen soorten 11

3.1.3 Aggregatie tot beleidsrelevante indicatoren 11

3.2 Gebruik modelresultaten Evaluatie Natuurpact $\quad 13$

$\begin{array}{lll}3.3 & \text { QUICKScan } & 13\end{array}$

3.3.1 QUICKScan softwaretool 13

3.3.2 QUICKScan als een aanpak 13

$\begin{array}{ll}\text { 3.3.3 Toepassingen van QUICKScan } & 14\end{array}$

$4 \quad$ Resultaten expertmeetings $\quad 15$

4.1 Integratie natuurbeleid $\quad 15$

4.1.1 Provinciaal beleid $\quad 15$

4.1.2 Derde partijen $\quad 15$

4.2 Agrarisch gebied 16

4.2.1 Natuurinclusieve landbouw 16

4.2.2 Landschapselementen; bomenrijen, sloten en bermen 16

$\begin{array}{lll}4.2 .3 \text { Handhaving } & 17\end{array}$

$\begin{array}{lll}4.3 & \text { Droge ecosystemen } & 17\end{array}$

$\begin{array}{lll}4.4 & \text { Aquatische natuur } & 17\end{array}$

4.5 Ambitiekaart $\quad 18$

4.6 Klimaatadaptatie $\quad 18$

$\begin{array}{lll}4.7 & \text { Geselecteerde gebieden/regio's } & 19\end{array}$

4.7.1 Veluwe 20

4.7.2 Bloemkampen $\quad 22$

$\begin{array}{lll}4.7 .3 & \text { Arkemheen } & 24\end{array}$

4.7.4 Groene Valleilint $\quad 26$

$\begin{array}{lll}4.7 .5 & \text { Binnenveld } & 28\end{array}$

$\begin{array}{lll}4.7 .6 & \text { Linge(dijk) } & 30\end{array}$

$\begin{array}{lll}4.7 .7 & \text { Rivierengebied } & 32\end{array}$

4.7.8 Hattem(erpoort) 34

4.7.9 Beken en sprengen IJsselvallei 36

4.7.10 Landgoederen Veluwe-IJssel/Zutphen 38

4.7.11 Grote Veld e.o. $\quad 40$

4.7.12 Baakse beek e.o. $\quad 42$

4.7.13 Groote beek $\quad 44$

$\begin{array}{lll}4.7 .14 & \text { Achterhoek } & 46\end{array}$

4.7.15 Winterswijk e.o. $\quad 48$

4.7.16 Montferland $\quad 50$

4.7.17 Gelderse poort $\quad 52$ 
4.7.18 Overasseltse en Hatertse vennen $\quad 54$

4.7.19 Bruuk 56

4.7.20 Gorsselse heide $\quad 58$

4.7.21 Huis Verwolde e.o. $\quad 60$

4.7.22 Lankheet e.o.

$\begin{array}{lll}4.8 & \text { Ecologische prioritering gebieden/regio's } & 63\end{array}$

$\begin{array}{ll}\text { Literatuur } & 65\end{array}$

$\begin{array}{lll}\text { Bijlage } 1 & \text { Domein en afbakeningen MNP } & 68\end{array}$

Bijlage 2 Korte beschrijving van invoerbestanden die gebruikt zijn $\begin{array}{ll}\text { bij de analyses van de Evaluatie Natuurpact } & 70\end{array}$

$\begin{array}{lll}\text { Bijlage } 3 & \text { Resultaten expertmeetings } & 72\end{array}$ 


\section{Samenvatting}

In de provincie Gelderland ligt meer dan 20\% van de Nederlandse terrestrische natuur. Gelderland heeft het grootste areaal aan heide en bos van Nederland. Momenteel komt qua verspreiding $15 \%$ van de Habitattypen, $14 \%$ van de Habitatrichtlijnsoorten en $12 \%$ van de broedvogels voor in Gelderland. Soorten die relatief veel voorkomen in de provincie en die landelijk een ongunstige staat van instandhouding hebben, zijn Draaihals, Kruisbek, Grote modderkruiper, Vliegend hert, Europese rivierkreeft, Boommarter en Gladde slang. Om de natuur in de provincie te behouden en de biodiversiteit te verbeteren, is de provincie Gelderland bezig met het opstellen van nieuw natuurbeleid.

Uit de recente evaluatie van het Natuurpact blijkt dat voor het vergroten van de biodiversiteit van de VHR meer inzet nodig is op verdroging, verzuring, vermesting en versnippering. De provincie Gelderland heeft behoefte aan inzicht waar en welke additionele maatregelen genomen moeten worden tegen deze drukfactoren. Doel van het project is om een goede onderbouwing te geven voor gebieden waar additionele maatregelen nodig zijn voor een verdere realisatie van de biodiversiteitsdoelstellingen van de Vogel- en Habitatrichtlijn in Gelderland.

Voor de onderbouwing is de kennis van de deskundigen uit de provincie en haar netwerk benut door twee expertmeetings te houden. De eerste expertmeeting is gehouden met de deskundigen van de provincie Gelderland en de tweede met deskundigen uit het netwerk van de provincie Gelderland. De deskundigen hebben in drie rondes aangegeven waar in Gelderland problemen spelen met betrekking tot respectievelijk i) verdroging, ii) vermesting en verzuring en iii) versnippering (de 'VER'-thema's). Vervolgens zijn de modelresultaten van de MNP (Model for Nature Policy) uit de evaluatie van het Natuurpact gebruikt om de knelpunten en mogelijke additionele maatregelen van de gebieden verder te bediscussiëren. Hierbij is gebruikgemaakt van de QUICKScan-tool die specifiek ontwikkeld is om in een multi-actoren workshop op een snelle, eenvoudige en transparante wijze ruimtelijke analyses uit te voeren en in beeld te brengen.

De discussies uit beide expertmeetings hebben geresulteerd in algemene aspecten die spelen rond natuur en biodiversiteit in de provincie Gelderland en het aanwijzen van 22 gebieden/regio's waar additionele maatregelen nodig zijn voor een verdere realisatie van de biodiversiteitsdoelstellingen van de Vogel- en Habitatrichtlijn in Gelderland. Voor een verdere realisatie is het belangrijk dat de provincie met andere sectoren samenwerkt. Door de deskundigen wordt ingeschat dat er vooral vanuit gezondheid en klimaatadaptatie kansen liggen om meer natuur te realiseren. De deskundigen geven aan dat in het landbouwgebied naast grote opgaven ook de grootste kansen liggen voor verdere biodiversiteitswinst. Via natuurinclusieve landbouw kunnen natuur en landbouw in samenhang worden gerealiseerd door optimaal gebruik te maken van de natuurlijke processen in het landschap en deze te integreren in de bedrijfsvoering. In het landelijk gebied liggen er ook kansen door landschapselementen te herstellen. Voor de natte elementen zal daarbij met waterschappen samengewerkt moeten worden.

Meer dan twee derde van de natuur in Gelderland bestaat uit bosgebieden en kent met de Veluwe het grootste terrestrische natuurgebied. In de bos- en heidegebieden op de zandgronden blijft de depositie van stikstof een knelpunt. Door de jarenlange depositie is de mineralenbalans op de zandgronden verstoord. Het is niet duidelijk op welke locaties additionele maatregelen nodig zijn voor het herstel van de bodems of dat deze problematiek in de hele provincie speelt. Door de deskundigen wordt voorgesteld om een programma voor bodemherstel op te zetten, waarbij door middel van gevarieerde pilots nagegaan kan worden welke maatregelen leiden tot een gezonde mineralenbalans.

Voor de 22 gebieden/regio's is een kenschets gegeven uit welke ecosystemen het gebied bestaat en welke drukfactoren opgelost moeten worden in het gebied voor de verdere realisatie van de biodiversiteitsdoelstellingen. Hiervoor is gebruik gemaakt van de resultaten uit de evaluatie van het 
Natuurpact. Het areaal in het gebied waar biodiversiteitswinst gerealiseerd kan worden, is gecombineerd met de resultaten uit de expertmeetings en het voorkomen van Vogel- en Habitatrichtlijnsoorten en -typen buiten de GNN om een prioriteit te geven. Deze prioriteit laat zien dat verwacht wordt dat de meeste biodiversiteitswinst gerealiseerd kan worden in Winterswijk e.o., de Veluwe en de Achterhoek. Daarnaast wordt ook een hoge biodiversiteitswinst verwacht wanneer maatregelen genomen worden in de Landgoederenzone tussen Veluwe en IJssel, Beken en Sprengen \& IJsselvallei en het Grote veld e.o. In het Groene Valleilint, Binnenveld, Rivierengebied en de Gelderse Poort liggen er ook kansen. Voor het Rivierengebied geven de deskundigen aan dat er specifieke kansen liggen bij mondingen van beken. Hier kunnen hogere ambities voor bijvoorbeeld moerastypen worden nagestreefd.

Deze top 10 moet als indicatie gezien worden. Enkele kanttekeningen zijn:

- alle ecosystemen en soorten worden even zwaar meegewogen en er is niet beoordeeld in hoeverre ze momenteel onder druk staan;

- er is geen rekening gehouden met de realiseerbaarheid van de biodiversiteitswinst. Zo geven de deskundigen aan dat voor een gezond ecosysteem in bijvoorbeeld het Binnenveld en de Achterhoek maatregelen op het schaalniveau van het landschap nodig zijn;

- er is geen rekening gehouden met de mogelijke effecten van klimaatverandering, waardoor bepaalde ecosystemen en soorten eerder onder druk komen te staan dan andere;

- er is geen rekening gehouden met knelpunten van aquatische natuur;

- de actuele VHR-waarden zijn gebaseerd op Bouwma et al. (2009). Mogelijk dat recentere gegevens tot een andere prioritering zouden leiden;

- bij de gekozen methode van prioritering zullen grotere gebieden/regio's eerder naar voren komen als prioritaire gebieden. 


\section{$1 \quad$ Inleiding}

\subsection{Achtergrond}

De provincie Gelderland is bezig met het opstellen van nieuw natuurbeleid. Aanleiding is onder andere het verschijnen van de lerende evaluatie van het PBL/WUR in januari 2017. Op basis van de evaluatie van het Natuurpact wordt in Nederland met het huidige afgesproken natuurbeleid, KRW-beleid en stikstofbronbeleid 65\% van de biodiversiteitsdoelstellingen van de Vogel- en Habitatrichtlijn (VHR) gehaald (PBL en WUR 2017). Om dichter bij 100\% biodiversiteitsdoelstellingen te komen, wordt verkend welke aanvullende maatregelen nodig zijn in Gelderland. Uit de evaluatie blijkt dat, voor het vergroten van de biodiversiteit van de VHR, meer inzet nodig is op verdroging, verzuring, vermesting en versnippering. De provincie Gelderland heeft behoefte aan inzicht waar en welke additionele maatregelen genomen moeten worden tegen deze drukfactoren.

Als onderdeel van het proces rondom het nieuwe natuurbeleid zijn de resultaten van de evaluatie gepresenteerd aan de provincie Gelderland programma Natuur en Landschap en haar netwerk. De provincie wil nu met deskundigen uit de provincie en haar netwerk kijken waar en hoe ze naast het reeds bestaande beleid verder kunnen komen met het behalen van de biodiversiteitsdoelstellingen voor het opstellen van het nieuwe natuurbeleid.

\subsection{Projectdoelstelling}

Doel van het project is om een goede onderbouwing te geven voor gebieden waar additionele maatregelen nodig zijn voor een verdere realisatie van de biodiversiteitsdoelstellingen van de Vogelen Habitatrichtlijn in Gelderland.

\subsection{Leeswijzer}

Deze rapportage dient als onderbouwing van het nieuwe natuurbeleid in Gelderland. In deze rapportage komen de volgende aspecten aan bod:

- Hoofdstuk 2: opzet van de expertmeetings om de kennis van de deskundigen uit de provincie en haar netwerk te benutten.

- Hoofdstuk 3: korte beschrijving van de MetaNatuurplanner (MNP), QUICKScan en van de analyses die met de MNP ten behoeve van de Evaluatie Natuurpact zijn uitgevoerd en de resultaten hiervan die gebruikt zijn in de expertmeetings. Voor de afbakening van het gebruik van de MNP wordt naar Bijlage 1 verwezen. Deze beschrijvingen zijn overgenomen uit Pouwels et al. (in prep.).

- Hoofdstuk 4: resultaten expertmeetings

In de bijlagen worden de resultaten van de aparte expertmeetings beschreven. 


\section{Expertmeetings}

Om de kennis van de deskundigen uit de provincie en haar netwerk te benutten, zijn twee expertmeetings gehouden. De eerste expertmeeting is gehouden met de deskundigen van de provincie Gelderland en de tweede met deskundigen uit het netwerk van de provincie Gelderland (Tabel 1, Figuur 1). In beide workshops is de deskundigen gevraagd om in drie rondes aan te geven waar in Gelderland problemen spelen met betrekking tot respectievelijk i) verdroging, ii) vermesting en verzuring en iii) versnippering. Deskundigen mochten 3-5 gebieden aanwijzen. Na de aanwijzing van de gebieden door de deskundigen is per aspect het resultaat naast de resultaten van de MNP uit de Evaluatie NatuurPact gelegd (Van der Hoek et al. 2017; Pouwels et al. (in prep.)). Voor de verschillende gebieden/regio's zijn de overeenkomsten en verschillen bediscussieerd en zijn oplossingsrichtingen voor de ingeschatte knelpunten geformuleerd. Hierbij is gebruikgemaakt van de QUICKScan-tool (http://www.quickscan.pro/; zie § 3.3).

\section{Tabel 1 Aanwezigen bij de expertmeetings.}

\begin{tabular}{ll}
$1^{e}$ expertmeeting & $2^{e}$ expertmeeting \\
Jaap Ex & Arthur Ebregt (Kroondomein Het Loo) \\
Marius Bolck & Volkert Vintgens (GNMF) \\
Johan Cronau & Merijn Biemans (Natuurmonumenten) \\
Joost van Kuijk & Jakob Leidekker (Hoge Veluwe) \\
Dick van Hoffen & Erik Klein Lebbink (Staatsbosbeheer) \\
Henri Stakenburg & Jaap Bouwman (Bosgroepen) \\
Teun Spek & Bernard Oosting (GNMF) \\
Bert Meijers & Dick van Hoffen (Gelderland) \\
Gert Jan de Fijter & Lyda Dik (Gelderland) \\
Marianne van der Veen & Rogier Pouwels (WEnR) \\
Lyda Dik & Peter Verweij (WEnR) \\
Rogier Pouwels (WEnR) & René Jochem (WEnR) \\
Peter Verweij (WEnR) & Joep Frissel (WEnR) \\
René Jochem (WEnR) & \\
Joep Frissel (WEnR) & \\
\hline
\end{tabular}

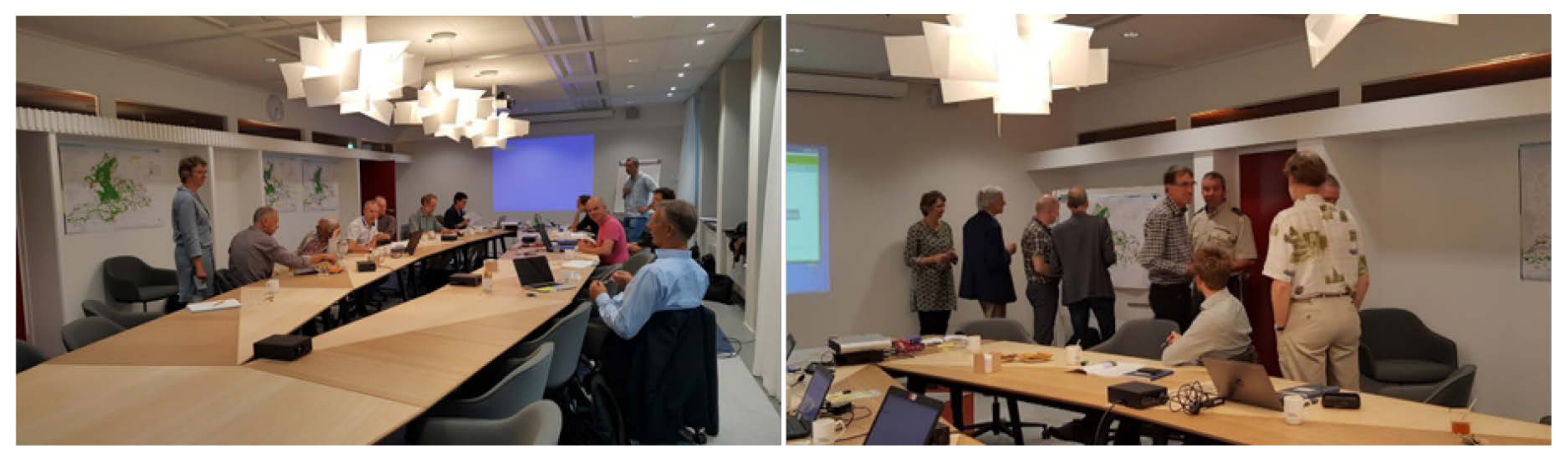

Figuur 1 Impressie van eerste (links) en tweede (rechts) expertmeeting. 


\section{Gebruikte gegevens en tools}

\subsection{MNP 4.0 in a nutshell}

De MNP bepaalt de effecten van beleid en beheeringrepen op de biodiversiteit. Het model legt relaties tussen de milieu-, water- en ruimtecondities en de duurzame instandhouding van de biodiversiteit. De output wordt geaggregeerd tot indicatoren die aansluiten op het Nederlandse en Europese beleid. De resultaten van het model sluiten aan op de langetermijndoelen van de Vogel- en Habitatrichtlijnen en de biodiversiteitsdoelen in het kader van de Europese Biodiversiteitsstrategie (CBD 2010, 2014).

Het basisconcept van het model sluit aan bij enkele belangrijke adviezen voor het behoud van biodiversiteit die de laatste jaren zijn gepubliceerd. Zowel Hodgson et al. (2011), Ovaskainen (2013) als Lawton et al. (2010) geven aan dat voor het behoud van biodiversiteit met name grote aaneengesloten gebieden met goede kwaliteit belangrijk zijn. Het advies van Ovaskainen (2013) is specifiek gericht op het Nederlandse natuurbeleid. In de MNP is dit basisconcept geïmplementeerd in drie stappen (Figuur 2), waarbij het landschap vanuit de ogen van soorten wordt bekeken. Deze drie stappen komen overeen met de opzet van ecologische modellen volgens Ferrier en Drielsma (2010) en is conceptueel niet gewijzigd ten opzichte van de MetaNatuurplanner 2.0 (zie ook Pouwels et al.

2016):

1. De kwaliteit van leefgebieden wordt bepaald aan de hand van de lokale milieudruk op de natuur op basis van een eenvoudige HSI-modelstructuur (Habitat Suitability Index; US Fish and Wildlife Service 1981). Voor elke soort worden de eisen die deze soort stelt aan zijn leefgebied vergeleken met de milieuomstandigheden in het te beoordelen scenario.

2. De mate waarin een aaneengesloten gebied groot genoeg is en voldoende kwaliteit heeft om een stabiele populatie ${ }^{1}$ voor een soort te kunnen garanderen, wordt bepaald. Vervolgens wordt nagegaan of er in het studiegebied voldoende grote aaneengesloten gebieden zijn met een goede kwaliteit om het duurzaam voortbestaan van een soort in het landschap te kunnen garanderen.

3. De resultaten worden samengevat in beleidsrelevante indicatoren, een soortindicator en een ecosysteemindicator, die gekoppeld kunnen worden aan beleidsdoelen.

\footnotetext{
1 Hierbij wordt gebruikgemaakt van het concept van sleutelgebieden (Verboom et al. 2001; paragraaf 2.11 in Pouwels et al. 2016) en bestaat er een zekere uitruil tussen de oppervlakte en de kwaliteit van het leefgebied. Als de kwaliteit lager is, zal het gebied groter moeten zijn.
} 


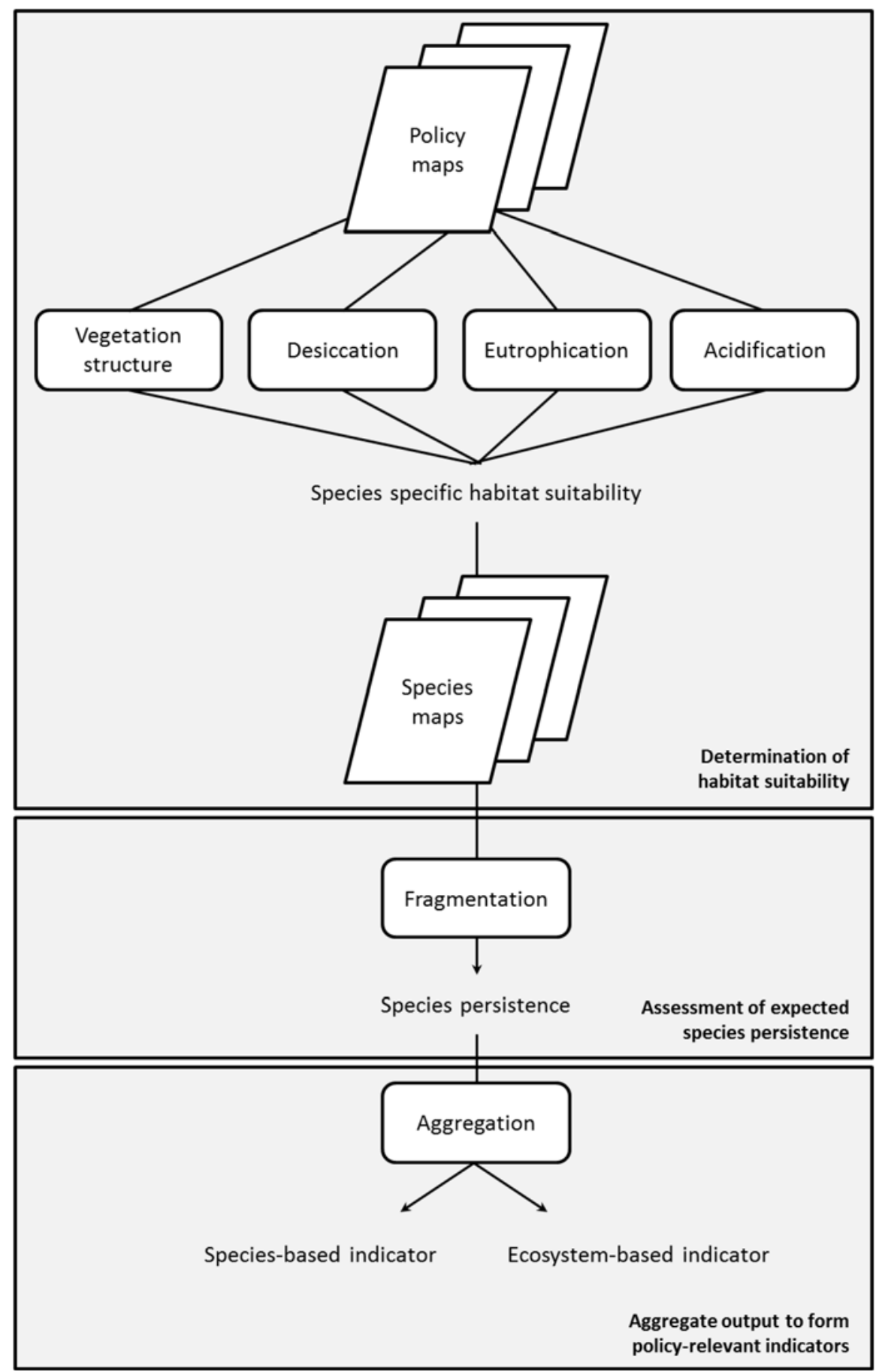

Figuur 2 Schematische weergave van de werkwijze van de $M N P^{2}$.

\subsubsection{Bepalen kwaliteit leefgebied}

De kwaliteit van het leefgebied van soorten wordt bepaald door een combinatie van biotische en abiotische omstandigheden (Grinnell, 1917; Hirzel en Le Hay, 2008). Een basisvoorwaarde voor het voorkomen van soorten is het aanwezige ecosysteem; moerassoorten kunnen alleen geschikt leefgebied hebben in een moerasecosysteem en niet in een bossysteem. Binnen verschillende ecosystemen komen de biotische relaties, zoals waardplant-vlinder, prooi-predator en soortconcurrentie, van nature voor en kennen feedbackmechanismes waardoor ze elkaar in evenwicht houden (Pimm, 1982). Al zijn deze interacties samen complex en per definitie niet stabiel (Montoya et al. 2006), de complexiteit van het geheel is erg belangrijk voor een stabiel voorkomen van een

2 Figuur gebaseerd op Pouwels et al. (2016b). In de beschrijving van die versie is acidification (verzuring) echter nog niet geïmplementeerd en dus niet beschreven. 
soort binnen dit systeem (Bascompte en Jordano, 2007). Het gaat ervan uit dat de interacties binnen de systemen voor deze stabiliteit zorgen en houdt geen rekening met deze specifieke interacties. De laatste jaren is het beheer van de natuur in Nederland vooral gericht op het herstellen of mitigeren van abiotische omstandigheden van ecosystemen. Vermesting, verdroging, verzuring en versnippering worden als belangrijkste drukfactoren van de terrestrische natuur gezien (Wamelink et al. 2013) en bepalen in Nederland in belangrijke mate de verspreiding en populatiegrootte van VHR-soorten (Van Kleunen et al. 2008). In de MNP worden de eerste drie factoren meegenomen bij de bepaling van de geschiktheid van het leefgebied ${ }^{3}$. Versnippering wordt meegenomen in de volgende stap van de MNP.

\subsubsection{Bepalen duurzaam voorkomen soorten}

Naast de achteruitgang van de kwaliteit van het leefgebied zijn in Nederland veel natuurgebieden kleiner en geïsoleerder geraakt (Jongman, 2002). Het concept van het Natuur Netwerk Nederland (NNN) is specifiek gericht op het tegengaan hiervan en zelfs op het deels herstellen. In hoeverre de gebieden groot genoeg zijn voor een soort om duurzaam voor te komen, hangt van soortspecifieke eigenschappen af. Wespendief en Blauwe kiekendief hebben grote oppervlakten aaneengesloten leefgebied nodig om een stabiele populatie te kunnen herbergen (Verboom et al. 2001), terwijl voor sommige vlinders en plantensoorten een geschikt leefgebieden snel geïsoleerd ligt vanwege een beperkte dispersiecapaciteit (Opdam et al. 2003). Theoretisch kan een soort duurzaam voorkomen in een landschap als er één grote levensvatbare populatie aanwezig is. Omdat catastrofes kunnen leiden tot het plotseling verdwijnen van een grote populatie, wordt een soort met de MNP als duurzaam aangeduid als er meerdere grote populaties voorkomen. Hierbij wordt gebruikgemaakt van het concept van sleutelgebieden (Verboom et al. 2001). Het aantal populaties dat nodig is, hangt af van de mate waarin een soort gevoelig is voor catastrofes (Foppen et al. 1998). Vlinders zijn gevoeliger voor stochastische processen dan vaatplanten en vogels ${ }^{4}$.

\subsubsection{Aggregatie tot beleidsrelevante indicatoren}

De MNP levert veel tussen- en eindresultaten per soort op. Door deze te aggregeren, kunnen de resultaten als beleidsrelevante indicatoren worden weergegeven. Door de resultaten te presenteren als indicator die door het beleid wordt nagestreefd, kan deze als grensobject (Star \& Griesemer, 1989) gaan dienen. De MNP aggregeert de eindresultaten tot twee indicatoren, een soortindicator en een ecosysteemindicator ${ }^{5}$. De soortindicator is in de Evaluatie van het Natuurpact gebruikt om aan te geven dat de plannen van de provincie zullen leiden tot 10 procent winst voor de doelstellingen van de VHR (Figuur 3). De ecosysteemindicator is gebruikt binnen de expertmeetings. Door verschillende scenario's met elkaar te vergelijken voor deze indicator, kan lokaal aangeven worden waar nog biodiversiteitswinst mogelijk is gezien de knelpunten qua verdroging, vermesting, verzuring en versnippering (Figuur 4).

\footnotetext{
Zie voor een meer gedetailleerde uitwerking van deze stap ook Pouwels et al. (2016a) §2.4-§2.6.

Zie voor een meer gedetailleerde uitwerking van deze stap ook Pouwels et al. (2016a) §2.10, §2.11 \& §2.13.

5 Zie voor een meer gedetailleerde uitwerking van deze stap ook Pouwels et al. (2016a) §2.2, §2.3 \& §2.14.
} 
Inschatting doelbereik van Vogel- en Habitatrichtlijn

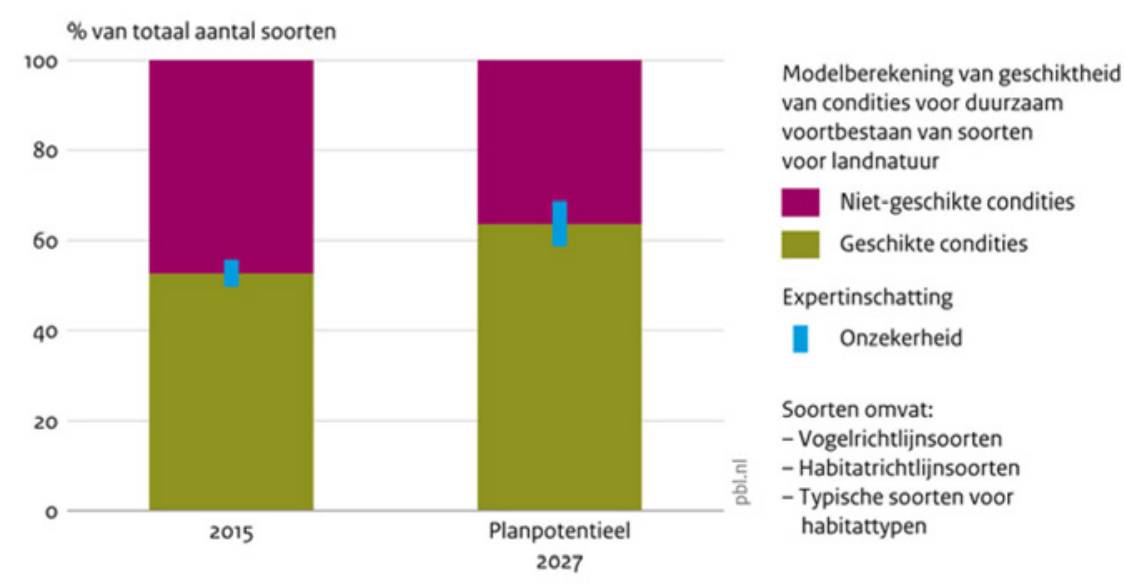

Bron: PBL; Wageningen University \& Research

Figuur 3 Eindresultaat van de MNP uit het rapport lerende evaluatie van het Natuurpact (PBL en WUR 2017).

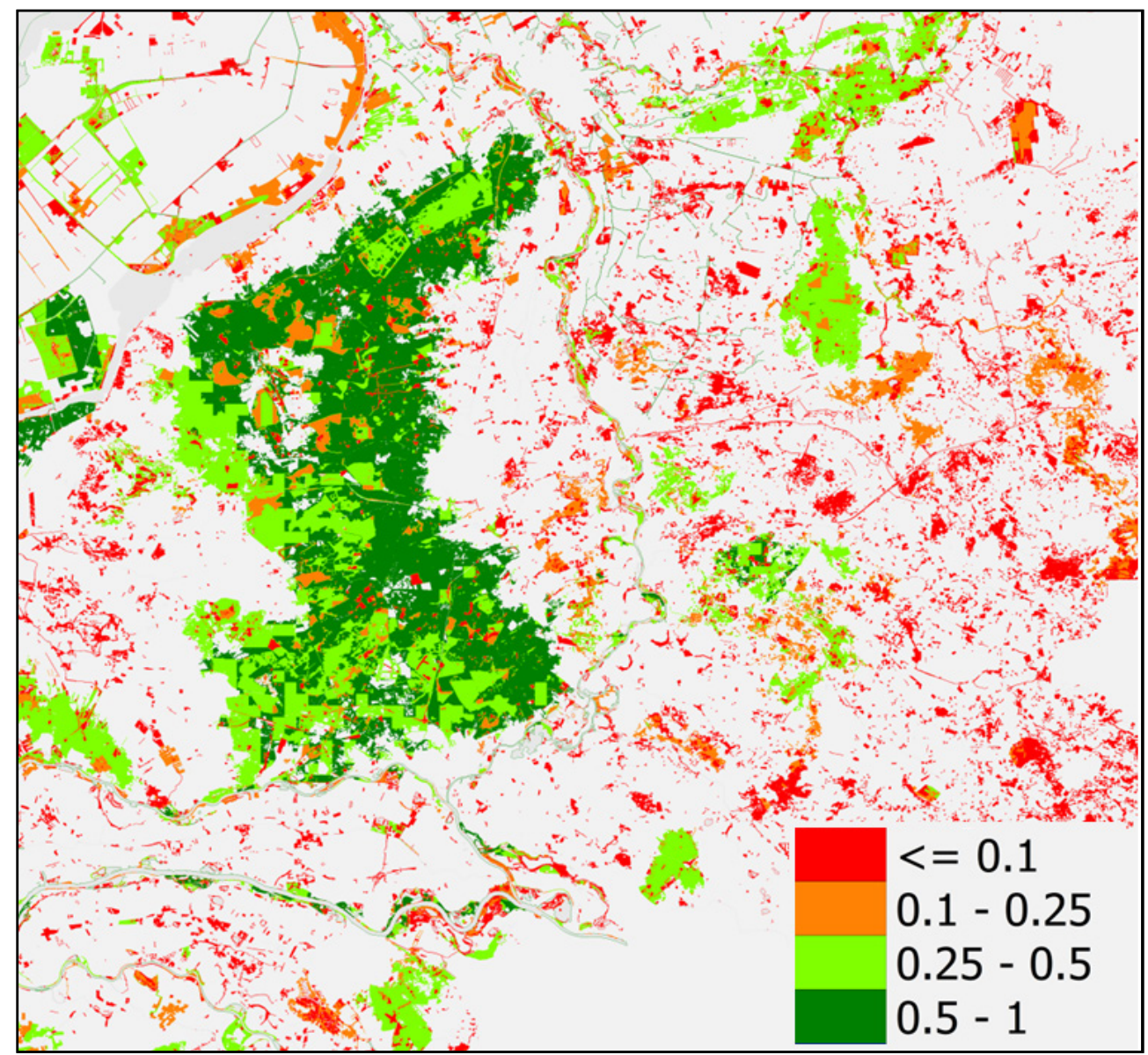

Figuur 4 Resultaat van de ecosysteemindicator op basis van de huidige situatie voor de Evaluatie Natuurpact. 


\subsection{Gebruik modelresultaten Evaluatie Natuurpact}

Bij de expertmeetings zijn de modelresultaten van de MNP gebruikt die voor de Evaluatie Natuurpact zijn uitgevoerd. Er is gebruik gemaakt van drie basisscenario's: huidige situatie, plan potentieel en uitvoeringspotentieel. Naast deze basisscenario's is nog een vijftal alternatieve scenario's doorgerekend om inzicht te krijgen in de gevolgen van de verschillende drukfactoren. Deze alternatieve scenario's zijn varianten op de geplande natuur, zoals weergegeven in de zogenaamde Ambitiekaart, uit plan potentieel ${ }^{6}$ :

1. toekomstige natuur met huidige condities;

2. toekomstige natuur met optimale condities voor verdroging, vermesting én verzuring;

3. toekomstige natuur met optimale condities ten aanzien van verdroging;

4. toekomstige natuur met optimale condities ten aanzien van vermesting;

5. toekomstige natuur met optimale condities ten aanzien van verzuring.

Voor de uitwerking van deze basisscenario's wordt verwezen naar Van der Hoek et al. (2017).

Door de verschillende scenario's en alternatieven met elkaar te vergelijken, kan inzicht gekregen worden in waar nog biodiversiteitswinst is te behalen. De vergelijking tussen de huidige situatie en het planpotentieel met optimale condities voor verdroging geeft weer waar biodiversiteitswinst te realiseren is als het knelpunt van verdroging wordt opgelost. Met name de nieuwe natuurgebieden laten een grote winst zien, omdat deze in de analyses van de huidige situatie geen natuur bevatten. De vergelijking tussen het planpotentieel en het planpotentieel met optimale condities ten aanzien van verdroging geeft weer waar biodiversiteitswinst te realiseren is als het knelpunt van verdroging wordt opgelost boven op de reeds geplande maatregelen.

\subsection{QUICKScan}

QUICKScan is een makkelijk te gebruiken onderzoeks-hulpmiddel dat snel, eenvoudig en transparant is, weinig invoerdata nodig heeft en ingezet kan worden in een multi-actoren workshop. QUICKScan maakt gebruik van concepten en methodes uit de wereld van participatief modelleren en participatief GIS, en gebruikt visualisatie- en interpretatiehulpmiddelen om de verkenning van opties tijdens groepsdiscussies te ondersteunen (Verweij et al. 2016).

\subsubsection{QUICKScan softwaretool}

De QUICKScan softwaretool is een hulpmiddel om expertkennis te combineren met ruimtelijke en statistische gegevens in een ruimtelijke modelleeromgeving. Resultaten worden weergegeven in interactieve (verschil)kaarten, samenvattende tabellen en grafieken en trade-off grafieken. Expertkennis wordt in de vorm van modelleerkennis in het systeem opgenomen. Afhankelijk van de toepassing kunnen verschillende vormen van modelregels door elkaar gebruikt worden, waaronder causale, kwalitatieve redeneringen (bijv. 'natuur van onvoldoende kwaliteit'), statistiek met onzekerheden, multicriteria en duurzaamheids- of draagkrachtgrenzen. Het systeem kan vanuit de visualisaties op transparante wijze de toegepaste regels en de doorwerking daarvan op de resultaten tijdens de groepsdiscussies tonen, zodat deelnemers inzicht krijgen in de doorwerking van de expertkennis.

\subsubsection{QUICKScan als een aanpak}

QUICKScan is een participatieve modelleringsmethode die de kennis en voorkeuren van stakeholders en beslissers koppelt aan beschikbare ruimtelijke en statistische gegevens. QUICKScan is ontworpen voor groepsgebruik, waarbij in workshops een iteratieve aanpak gevolgd wordt. Van eenvoudige (op kennis gebaseerde) basisregels tot complexe vraagstukken, waarbij stap-voor-stap de complexiteit toeneemt op basis van de door deelnemers bediscussieerde tussenresultaten. Opeenvolgende iteraties worden gebruikt om 1) de kwaliteit van het model te verbeteren, 2) om alternatieve (ruimtelijke)

\footnotetext{
6 In Bijlage 2 wordt een korte beschrijving gegeven van de gebruikte invoerbestanden.
} 
plannen en beleidsopties uit te proberen en 3) om verschillende waarden en perspectieven van belanghebbenden te evalueren.

\subsubsection{Toepassingen van QUICKScan}

QUICKScan is gebruikt voor meer dan 80 verschillende omgevingsevaluaties op verschillende ruimtelijke schalen en op verschillende locaties over de hele wereld. Maatschappelijke en milieucondities worden beoordeeld, patronen en interacties worden geanalyseerd, alternatieve reacties worden gemodelleerd en de impact van de uitkomsten worden geëvalueerd. QUICKScan wordt gebruikt voor desktoponderzoek en wordt binnen de participatieve methode ook als discussie ondersteunend hulpmiddel gebruikt.

Een selectie van de toepassingen is te vinden op http://www.quickscan.pro/cases. 


\section{$4 \quad$ Resultaten expertmeetings}

Beide expertmeetings hebben geresulteerd in algemene discussies die spelen rond natuur en biodiversiteit in de provincie Gelderland. Tevens is een aantal gebieden/regio's benoemd waar extra inspanningen naar verwachting kunnen leiden tot een biodiversiteitswinst. Deze gebieden/regio's worden apart besproken. Voor een overzicht van de aangewezen gebieden en een kort verslag van de discussies bij beide expertmeetings, wordt verwezen naar Bijlage 3.

In de onderstaande paragrafen wordt een samenhangend verslag gegeven van de punten die de verschillende deskundigen hebben aangedragen. Hierbij zijn de discussies van beide expertmeetings samengevoegd en worden geen aparte thema's onderscheiden.

\subsection{Integratie natuurbeleid}

\subsubsection{Provinciaal beleid}

Het huidige natuurbeleid is erop gericht om niet alleen natuurdoelen na te streven, maar ook betrokkenheid van de maatschappij en een betere samenhang van economische activiteiten met natuur. Hierbij dient men rekening te houden met de diversiteit aan beelden die leven in de maatschappij (Mace, 2014). Om de kracht van deze diversiteit beter te kunnen benutten, dient natuur niet alleen vanuit het oogpunt van behoud biodiversiteit benaderd te worden (PBL \& WUR 2017b). Voor het realiseren van meer betrokkenheid en een betere samenhang met economische activiteiten zal het natuurbeleid dan ook beter geïntegreerd moeten worden in andere beleidsvelden. Door de deskundigen wordt aangegeven dat vanuit het thema gezondheid mogelijk zelfs meer natuur is te realiseren dan vanuit het thema biodiversiteit. In het beleid wordt contact met natuur gestimuleerd en natuurgebieden spelen daarbij een belangrijke rol (Maller et al. 2006; Bell et al. 2007). Ook vanuit het thema klimaatadaptatie kan mogelijk meer natuur gerealiseerd worden (zie 4.6).

\subsubsection{Derde partijen}

Het behouden van de biodiversiteit - onder andere door middel van het herstel van natuurgebieden is momenteel een doel dat vanuit natuur wordt gerealiseerd. Vaak hebben andere sectoren ook profijt van deze natuur en worden meerdere diensten geleverd in natuurgebieden dan alleen het behoud van soorten. Ook zijn er steeds meer voorbeelden van problemen binnen andere sectoren die met natuurgerichte maatregelen opgelost worden. Zo draagt het aanleggen van groene daken en stedelijk groen bij om het hitte-eilandeffect tegen te gaan (Skelhorn et al. 2014). De afgelopen jaren is ook veel in natuur geïnvesteerd vanuit Ruimte voor de Rivier om de verhoogde risico's op wateroverlast door overstroming van de rivier tegen te gaan (bijv. de IJsselpoort;

https://www.natuurmonumenten.nl/nieuws/ijsselpoort-mooi-en-veilig-dankzij-bijdrage-postcodeloterij; Van Hattum et al. 2014). Ook kan natuur bijdragen aan efficiënte landbouw via een gezonde bodem (http://www.beterbodembeheer. $\mathrm{nl} / \mathrm{nl} /$ beterbodembeheer.htm) en via een goed insectenbestand ten behoeve van plaagregulatie en bestuiving (Vos et al. 2015). Dit betekent dat in Gelderland samenwerking gezocht kan met andere sectoren voor de verbetering van de biodiversiteit waar dit mogelijk en zinvol is. 


\subsection{Agrarisch gebied}

\subsubsection{Natuurinclusieve landbouw}

De provincie Gelderland kent grote oppervlaktes landbouwgebieden. In sommige regio's, zoals de Gelderse Vallei, is deze erg intensief en liggen natuurgebieden veelal geïsoleerd in het landschap. In andere regio's, zoals rond Winterswijk, zijn ondanks de intensieve landbouw nog veel natuurlijke elementen aanwezig, waardoor deze gebieden minder geïsoleerd liggen. Algemeen kan worden gesteld dat de meeste biodiversiteitswinst is te halen in de agrarische gebieden van Gelderland. Daar staat tegenover dat de opgave voor de landbouw ook het grootst is. Om deze biodiversiteitwinst te realiseren in het agrarisch gebied, zullen landbouw en natuur in samenhang moeten worden gerealiseerd: natuurinclusieve landbouw (zie o.a. Erisman et al. 2017). Daarbij wordt dan optimaal gebruik gemaakt van de natuurlijk processen in het landschap en geïntegreerd worden in de bedrijfsvoering. In natte gebieden kan bijvoorbeeld gedacht worden aan het telen van lisdodde dat verwerkt kan worden tot isolatiemateriaal. In de ene regio zal dit eenvoudiger te realiseren zijn dan in de andere regio. Door de deskundigen wordt aanbevolen om vooral naar mogelijkheden te kijken naar regio's rondom bestaande natuurgebieden die een kwaliteitsimpuls kunnen krijgen door de inzet van natuurinclusieve landbouw. Regio's die daarvoor in aanmerkingen komen, zijn onder andere landbouwenclave Uddel en Elspeet, Winterswijk e.o., Groene Valleilint, Grote Veld e.o.

Aangezien bij natuurinclusieve landbouw natuurlijk processen in het landschap aan de basis staan, is samenwerking met andere partijen, zoals collectieven, landbouw, gemeenten, waterschappen, essentieel aan deze nieuwe vorm van landbouw. Tevens vergt dit een verandering van de aansturing en subsidieverlening, zoals GLB. Daarbij dient niet beoordeeld te worden welke maatregelen er mogelijk zijn, maar dient er gefocust te worden op de vraag wat de problemen zijn waar de vergroening van het GLB zich op zou moeten richten (Van Doorn et al. 2017). Deze problemen betreffen met name 1) een duurzaam gebruik van bodem en water, 2) klimaatverandering en 3) behoud en ontwikkeling van de biodiversiteit. Daarbij zal er maatwerk in de regio geleverd moeten worden en lijkt er een belangrijke rol weggelegd te zijn voor de boerencollectieven (Van Doorn et al. 2017).

\subsubsection{Landschapselementen; bomenrijen, sloten en bermen}

Gelderland kent met regio's als de Graafschap en Winterswijk e.o. landschappen die nog steeds doorweven zijn met groene landschapselementen. Ondanks de waarde die deze elementen hebben voor natuur, recreatie en landbouw, o.a. plaagbestrijding, is de kwaliteit van veel elementen matig of slecht. Tevens wordt een deel van de elementen bedreigd door verwaarlozing, overmatige voedselrijkdom en bebouwing (http://landschapsbeheergelderland.nl/meetnet-agrarischcultuurlandschap/).

Naast het behoud en herstel van huidige elementen liggen er ook kansen voor verbeteringen van bermen en watergangen. In het landelijk gebied liggen veel kleine gronden die in eigendom zijn van de overheid, zoals bermen, dijken, oevers, overhoeken en tijdelijk braakterrein. Wanneer de verschillende overheden gezamenlijk inzetten op een meer ecologische inrichting en beheer, kunnen deze kansen benut worden. In de gemeente Berkelland zijn bijvoorbeeld de afgelopen jaren de bermen opnieuw natuurlijker ingericht

(https://www.youtube.com/watch?v=77V3Lib5yPk\&feature=youtu.be). Ook de waterschappen hebben in hun beheerplannen het verder creëren van natuurvriendelijke oevers opgenomen als een verdere verbetering van de ecologische waarden in het landelijk gebied (zie bijv. https://www.wrij.nl/waterbeheerplan/strategie-beleid/schoon-water/werken-goede/). 


\subsubsection{Handhaving}

De deskundigen geven aan dat naast een betere aansluiting van de bedrijfsvoering bij het landschap en de natuur, ook handhaving een substantiële bijdrage kan leveren. Het voorbeeld uit Berkelland laat zien dat handhaving het verdwijnen van landschapselementen had kunnen tegengaan. Ook zijn er nog problemen met luchtwassers op het gebied van handhaving. Het blijkt dat deze regelmatig niet goed functioneren of niet gebruikt worden door bijvoorbeeld de hoge energiekosten. Zeker waar stallen naast kwetsbare natuurgebieden liggen, kan dit lokaal grote consequenties hebben.

\subsection{Droge ecosystemen}

Gelderland kent met de Veluwe het grootste terrestrische natuurgebied van Nederland. Daarnaast zijn er veel grotere en kleinere bossen, heideterreinen en graslanden aanwezig ${ }^{7}$. Met name voor de ecosystemen op de zandgronden blijft de depositie van stikstof een knelpunt voor vermesting en verzuring. Ondanks dat veel PAS-maatregelen genomen gaan worden binnen Natura 2000-gebieden, is de inschatting dat deze maatregelen voor de droge ecosystemen niet voldoende effectief zullen zijn. Er zijn duidelijke indicaties dat in veel droge systemen op de hogere zandgronden geen goede mineralenbalans meer aanwezig is. Door de jarenlange druk vanuit de stikstofdepositie is op de Veluwe in de bovenste bodemlaag weinig calcium meer aanwezig. Dit resulteert in tekorten voor vogels via de bomen en planten naar de insecten (Van der Burg et al. 2017). Deze problematiek lijkt op grotere schaal te spelen. Recent onderzoek uit Duitsland laat zien dat de hoeveelheid insecten sterk is gedaald (http://www.sciencemag.org/news/2017/05/where-have-all-insects-gone). Aan de andere kant laat de trend van vogels in de Nederlandse bossen deze daling niet zien. Broedvogels nemen gemiddeld toe. Uitzondering daarop zijn de roofvogels op de zandgronden die vanwege de kwaliteit van hun prooien afnemen (http://www.clo.nl/indicatoren/nl1162-fauna-van-het-bos).

Gedurende de afgelopen decennia is de depositie van verzurende stoffen gehalveerd (http://www.clo.nl/indicatoren/nl0184-verzurende-depositie). Ondanks deze afname van depositie dienen de problemen rond verzuring opnieuw op de politieke agenda te komen. Door de jarenlange depositie is een tekort aan basische mineralen ${ }^{8}$ ontstaan. Gedacht wordt aan een programma voor bodemherstel, waarbinnen pilots (bijvoorbeeld het toepassen van steenmeel) uitgevoerd gaan worden en waarvan de resultaten geëvalueerd worden. Met deze vorm van adaptief management kan bijgestuurd totdat een beoogd doel bereikt is (Williams et al. 2007). Voor de droge bossen wordt door de deskundigen twee alternatieve maatregelen aangedragen. Er kan gekozen worden voor een mix van boomsoorten die mineralisatie in de bodem bevorderen. Daarnaast kan men dood hout en afvalhout bij de oogst laten liggen. Deze laatste oplossingsrichting wordt echter al uitgevoerd in de meeste gebieden. Tegelijkertijd met het uitvoeren van deze herstelmaatregelen zal ook de oorzaak aangepakt moeten worden.

\subsection{Aquatische natuur}

Een belangrijke kanttekening bij de expertmeetings is dat de aquatische kennis niet door de deskundigen vertegenwoordigd is. Tevens zijn de ondersteunende modelresultaten gericht op de terrestrische milieus. Ook het rivierengebied is onderbelicht geweest. Het is dan ook aan te bevelen om voor de watersystemen inclusief het rivierengebied aanvullende expertise in te winnen.

\footnotetext{
7 Qua oppervlakte is $25 \%$ van de bosgebieden in Gelderland kleiner dan 100 ha. Qua aantal is dit bijna $100 \%$. Voor heideterreinen geldt dat qua oppervlakte $20 \%$ kleiner is dan 100 ha en $99 \%$ qua aantal (achtergrond data van CLO indicator uit 2012; http://www.clo.nl/indicatoren/nl116105-versnippering-bos).

8 Met name Calcium, maar ook andere mineralen zijn van belang voor een gezond ecosysteem.
} 


\subsection{Ambitiekaart}

Het huidige natuurbeleid richt zich met name op realisatie van het Gelders Natuur Netwerk (GNN) de Natura 2000-gebieden en de soorten van de Vogel- en Habitatrichtlijn. De ambities die in de overige bestaande natuurgebieden worden nagestreefd, zijn opgenomen in de Ambitietypenkaart. De resultaten van de Evaluatie Natuurpact laten zien dat deze Ambitiekaart bij het achterhalen van knelpunten voor biodiversiteit erg sturend kan zijn. Het is daarom aan te bevelen om de ambities voor de verschillende natuurgebieden te evalueren, omdat de ambities mogelijk in sommige gebieden te laag zijn, terwijl ze in andere gebieden mogelijk te hoog zijn. Door de deskundigen wordt één voorbeeld van een mogelijk te lage ambitie aangedragen, de uiterwaarden van het rivierengebied, en één voorbeeld voor een mogelijk te hoge ambitie, bosgebieden in de Achterhoek.

In de uiterwaarden van het rivierengebied kunnen hogere ambities nagestreefd worden. De deskundigen verwachten dat met name bij beekmondingen de condities aanwezig zijn om moerasnatuur na te streven. De mondingen dienen dan beter ingericht te worden. In de Achterhoek liggen vooral veel kleine, geïsoleerde bosgebieden. Het is moeilijk om in deze gebieden gezonde bosecosystemen te realiseren. De deskundigen geven aan dat het in deze regio mogelijk beter is om landschappelijke natuur na te streven met leefgebieden voor soorten die van halfopen landschappen houden. Eventueel geplande verbindingszones zullen ook bijdragen aan het creëren van dit type landschappen.

\subsection{Klimaatadaptatie}

Klimaatverandering zal de komende jaren een impact hebben op de natuur in de provincie Gelderland. De mate van deze impact is moeilijk in te schatten, maar het is duidelijk dat zuidelijke soorten naar het noorden zullen opschuiven en dat sommige soorten zullen verdwijnen. Daarnaast zal door een toename van weersextremen ook de stabiliteit van lokale populaties verminderen. Om dit tegen te gaan, zullen grotere gebieden met gradiënten nodig zijn die onderling zijn verbonden (PBL 2010, 2012). In Gelderland zijn rivieren en beekdalen natuurlijke migratieroutes. Naast het robuuster maken van kwetsbare gebieden, zullen ook deze natuurlijke verbindingen versterkt moeten worden.

Om de klimaatverandering het hoofd te bieden, zullen niet alleen vanuit de natuursector adaptatiemaatregelen genomen worden. Om o.a. overstromingsrisico's en hittestress in steden tegen te gaan, zullen maatregelen genomen worden die mogelijk nieuwe natuur opleveren (zie ook 4.1.2). Ambities moeten dan afgestemd worden op de maatregelen die nodig zijn vanuit andere sectoren. 


\subsection{Geselecteerde gebieden/regio's}

Op basis van alle gebieden die door de deskundigen zijn aangewezen en bediscussieerd, zijn 22 gebieden genoemd waar additionele maatregelen tot een verdere biodiversiteitswinst zal leiden (Figuur 5). Per gebied wordt een korte kenschets gegeven en een overzicht van de resultaten van de MNP:

- In de kenschets wordt eerst aangegeven uit welke ecosystemen het gebied bestaat volgens de Beheertypenkaart (Huidige Beheertypen) en welke ambities worden nagestreefd (Ambitietypen). De mate waarin de ecosystemen in het gebied groot genoeg zijn om stabiele populaties van soorten te herbergen, wordt weergegeven door de 'intactness'. Tevens is aangegeven of er natuurontwikkeling nagestreefd wordt door middel van ecologische verbindingszones, groene ontwikkelzone, natte landnatuur of nieuwe natuur.

- Het overzicht van de resultaten van de MNP geeft het areaal weer waar biodiversiteitswinst te realiseren is wanneer een van deze 'VER'-thema's opgelost wordt in het gebied. Als laatste wordt het areaal aangegeven waar biodiversiteitswinst wordt gerealiseerd en wanneer alle knelpunten rond verdroging, vermesting en verzuring worden opgelost worden (Optimaal).

Tevens wordt een korte samenvatting gegeven van de problematiek die volgens de deskundigen in het gebied speelt en de oplossingsrichtingen die zijn aangedragen.

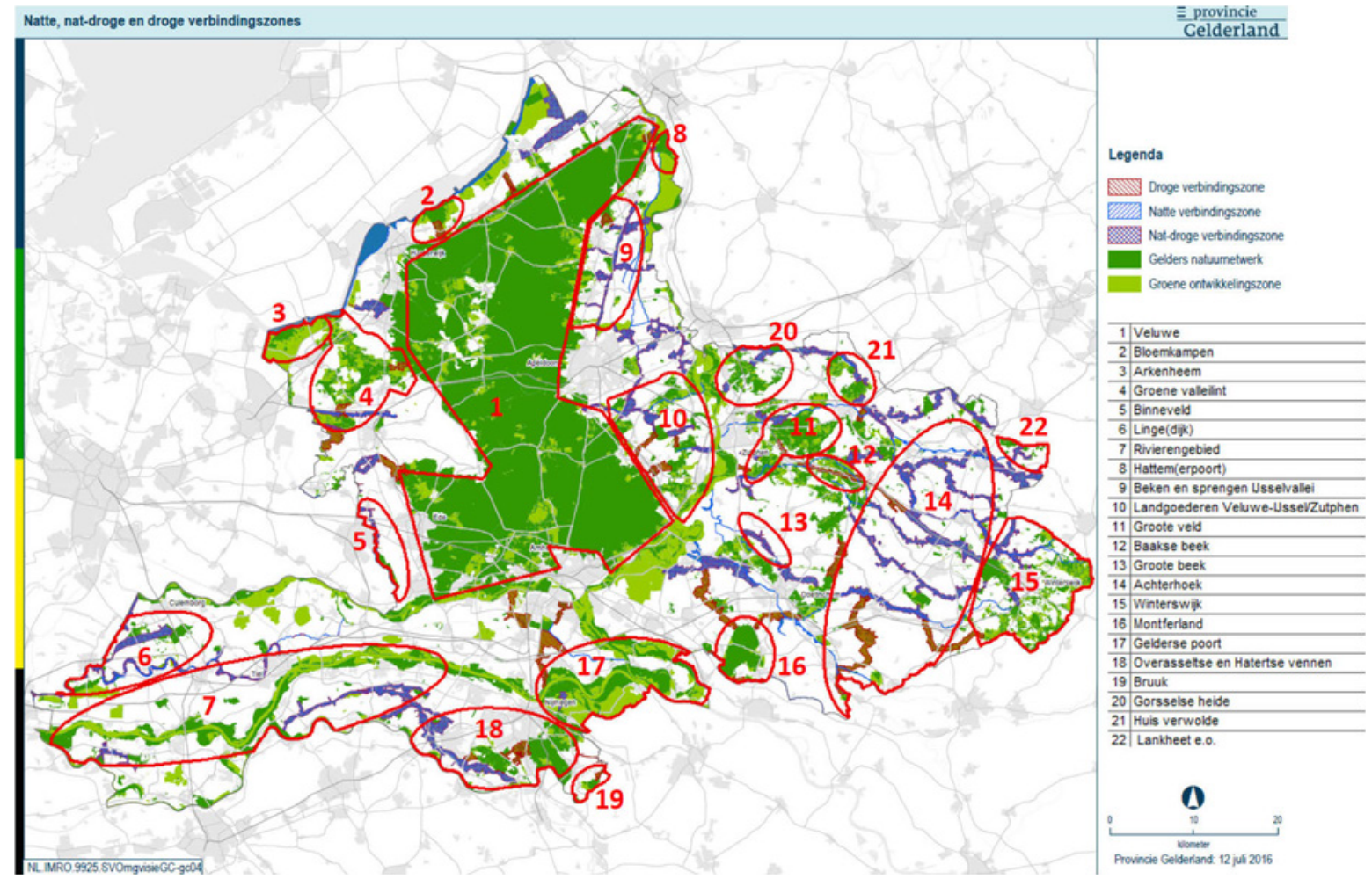

Figur 5 Gebieden/regio's die door de deskundigen van de provincie zijn aangestipt en bediscussieerd bij een of meerdere thema's. 


\subsubsection{Veluwe}

De Veluwe is een groot, aaneengesloten natuurgebied waar met name de omzetting van bos naar heide wordt nagestreefd. Rond de Veluwe liggen ook gebieden in de Groene ontwikkelzone (Figuur 6). In het gebied spelen met name knelpunten rond vermesting en verzuring (Figuur 7). De deskundigen geven aan dat daarnaast ook lokale waterwinning tot verdroging van sprengen en beken leidt. Tevens speelt interne versnippering van het gebied een rol. Sommige heideterreinen liggen geïsoleerd tussen de bosgebieden en ook de infrastructuur doorsnijdt de Veluwe op veel plekken. De verzuring van de Veluwe is tijdens beide bijeenkomsten door de deskundigen aangedragen als een van de grote, nieuwe knelpunten (zie 4.3). Als laatste speelt op de Veluwe verstoring door recreatie een rol in het behoud van met name vogelsoorten. Een goed zoneringsplan zal nodig zijn om met name soorten van open natuurtypen te behouden. Daarbij zullen beheerders samen afspraken moeten maken waar recreatie geïntensiveerd mag worden en waar rustgebieden gecreëerd worden (Pouwels et al. 2017).

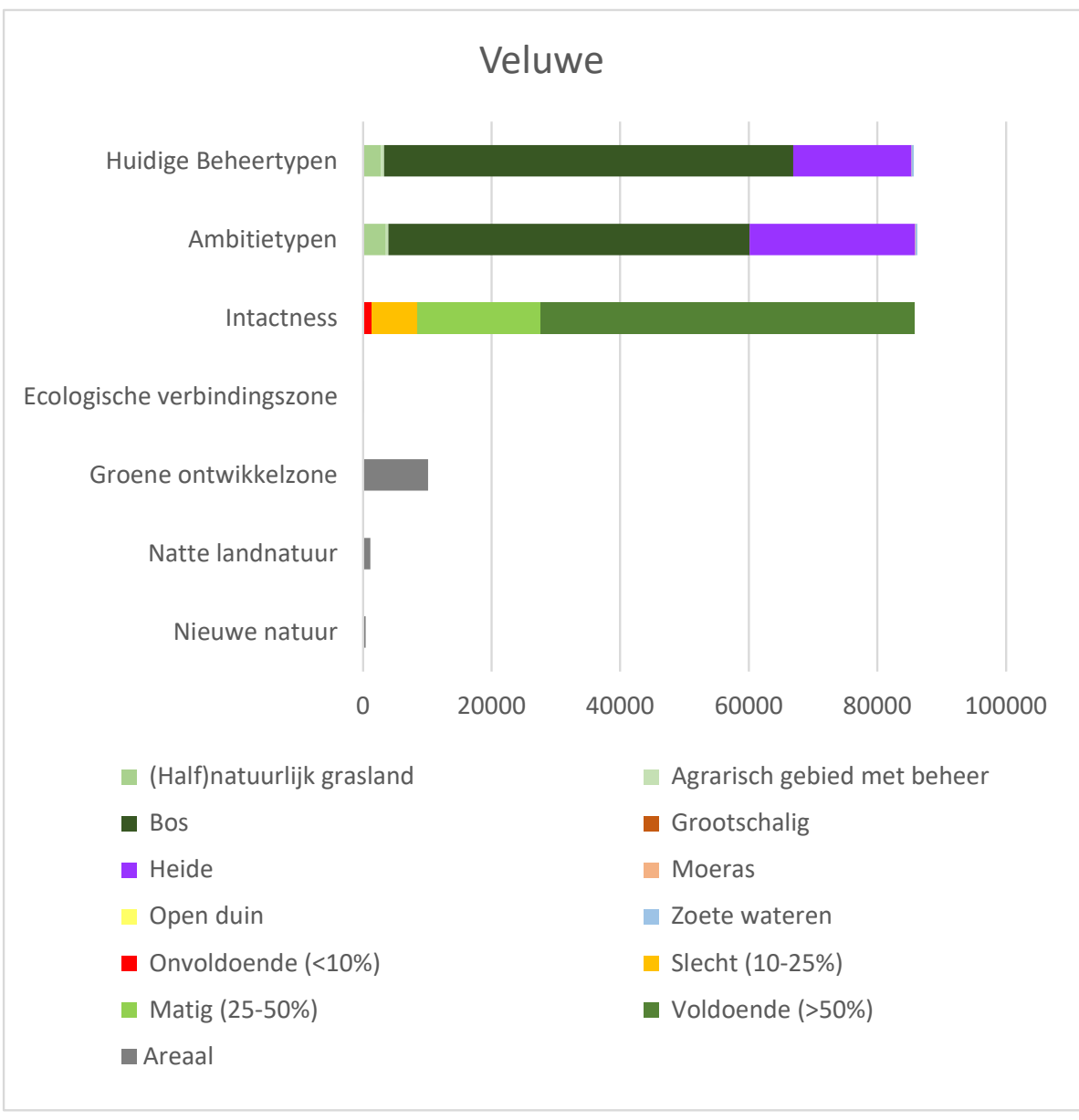

Figuur 6 Kenschets van de Veluwe in hectare. (Zie 4.7 voor uitleg figuur.) 


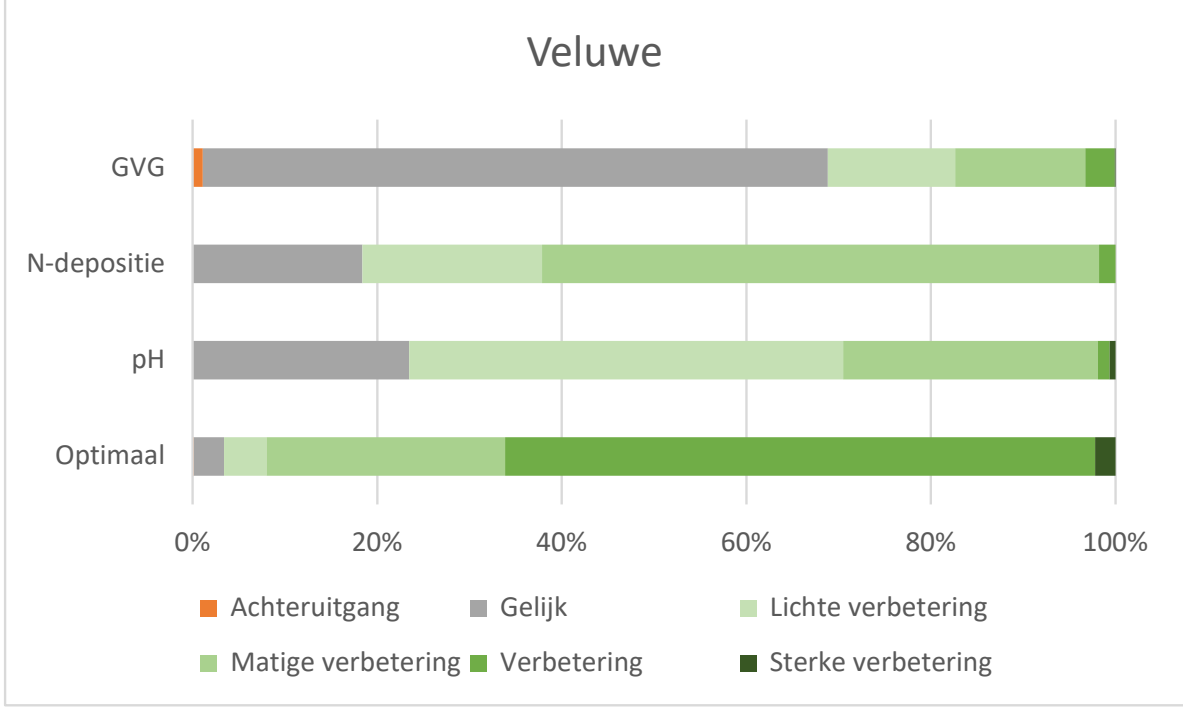

Figuur $7 \quad M N P$-resultaten m.b.t. verdroging (GVG), vermesting ( $N$-depositie) en verzuring $(p H)$ voor de Veluwe. De staafdiagrammen geven het percentage van het areaal weer waar biodiversiteitswinst te realiseren is wanneer een van deze VER-thema's opgelost wordt en wanneer ze allemaal opgelost worden (Optimaal). Door de deskundigen is aangegeven dat de resultaten met betrekking tot verdroging voor de Veluwe met voorzichtigheid moeten worden gehanteerd. De huidige invoerbestanden geven lokale situaties met zogenaamde schijngrondwaterstanden niet goed weer. 


\subsubsection{Bloemkampen}

De Bloemkampen is een natuurgebied waar met name de (half)natuurlijke graslanden worden nagestreefd. De Ambitiekaart laat zien dat het areaal (half)natuurlijke graslanden met 50\% zal toenemen. Tevens liggen er in en om het gebied veel gebieden waar nieuwe natuurontwikkeling wordt nagestreefd (Figuur 8). In het gebied speelt met name het knelpunt rond verdroging (Figuur 9). Ook laat de intactness zien dat het gebied nog geïsoleerd ligt en onvoldoende robuust is (Figuur 8). De deskundigen geven aan dat er in Noord-Brabant ervaringen zijn door lokaal percelen te creëren die geschikt zijn voor weidevogels die mogelijk als voorbeeld kunnen dienen voor graslanden langs de randmeren.

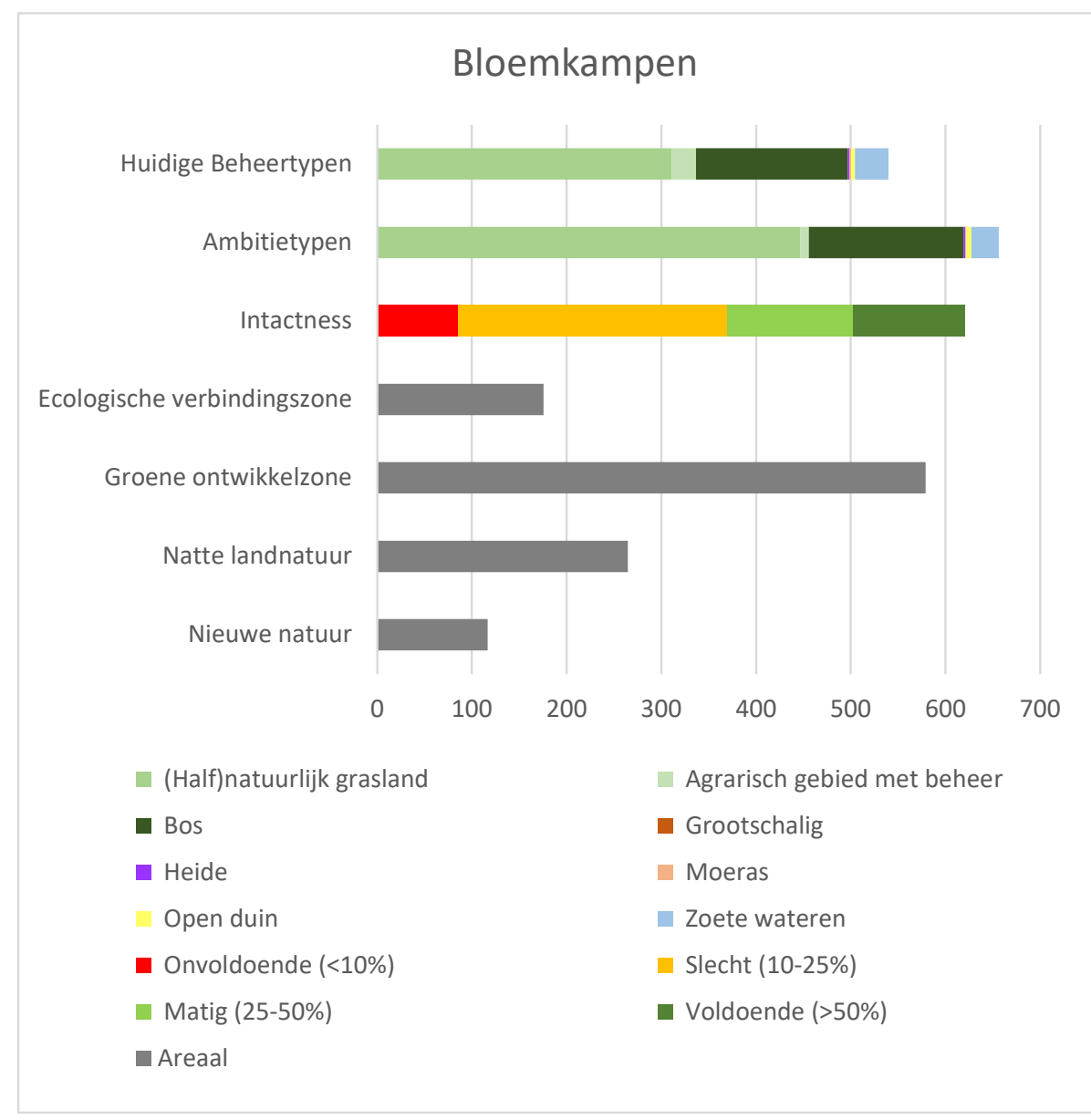

Figuur $8 \quad$ Kenschets van de Bloemkampen in hectare. (Zie 4.7 voor uitleg figuur.) 


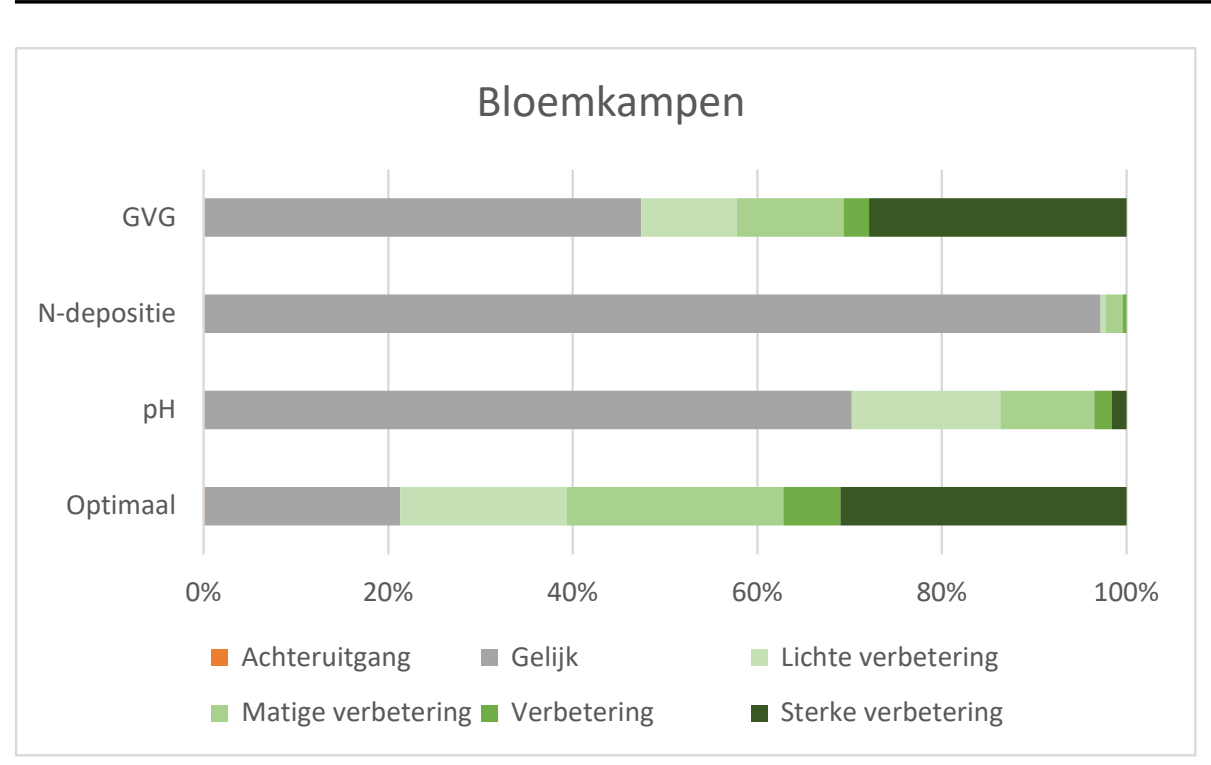

Figuur $9 \quad M N P$-resultaten m.b.t. verdroging (GVG), vermesting ( $N$-depositie) en verzuring $(\mathrm{pH})$ voor de Bloemkampen. De staafdiagrammen geven het percentage van het areaal weer waar biodiversiteitswinst te realiseren is wanneer een van deze VER-thema's opgelost wordt en wanneer ze allemaal opgelost worden (Optimaal). 


\subsubsection{Arkemheen}

Arkemheen is een natuurgebied waar met name de agrarische graslanden met beheer ten behoeve van weidevogels wordt nagestreefd. De ambitiekaart laat zien dat er een kleine toename wordt nagestreefd van (half)natuurlijke graslanden. Er liggen met name gebieden in de Groene ontwikkelzone (Figuur 10). De MNP-resultaten laten zien dat, wanneer de provinciale plannen worden uitgevoerd, er nauwelijks knelpunten meer aanwezig zijn in het gebied (Figuur 11). Dit wordt tevens bevestigd door de deskundigen.

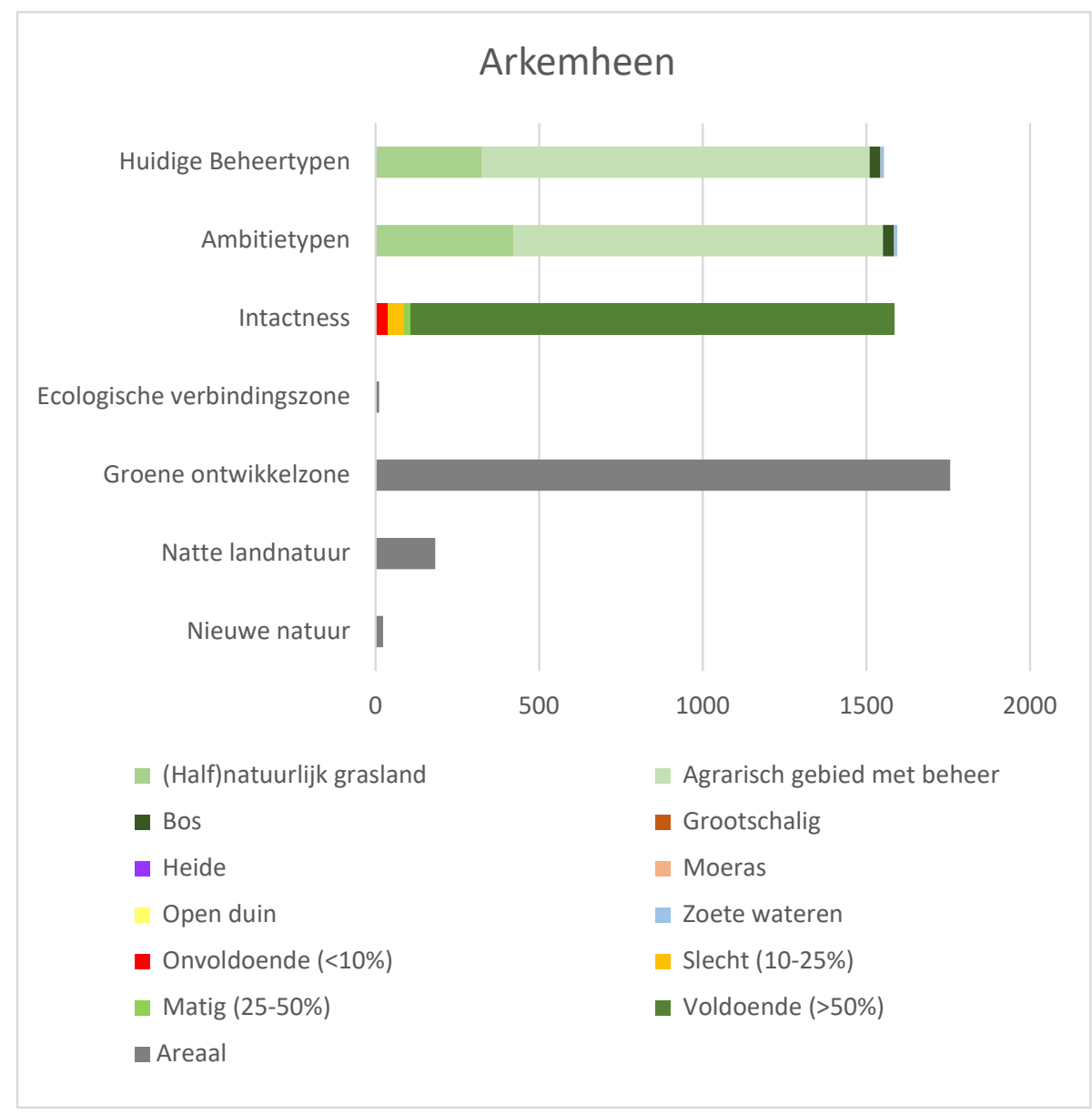

Figuur 10 Kenschets van Arkemheen in hectare. (Zie 4.7 voor uitleg figuur.) 


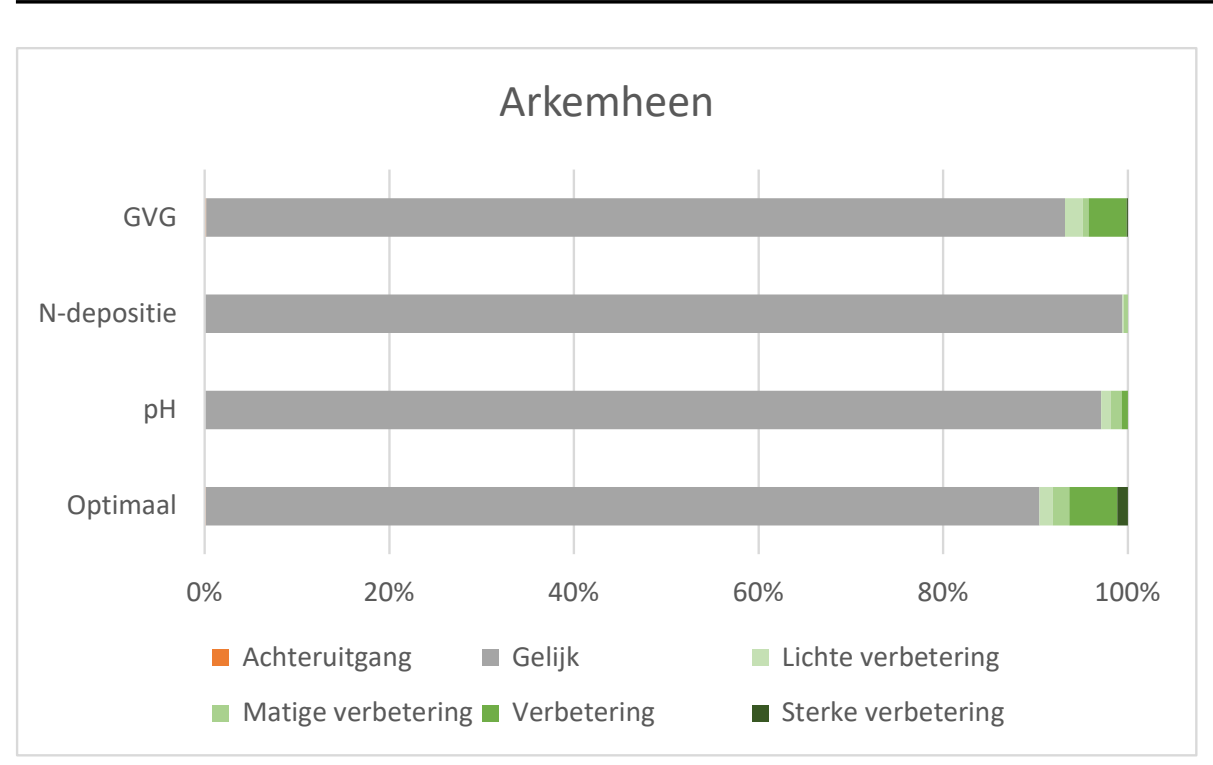

Figuur 11 MNP-resultaten m.b.t. verdroging (GVG), vermesting ( $N$-depositie) en verzuring $(p H)$ voor Arkemheen. De staafdiagrammen geven het percentage van het areaal weer waar winst voor de biodiversiteit te realiseren is wanneer een van deze VER-thema's opgelost wordt en wanneer ze allemaal opgelost worden (Optimaal). 


\subsubsection{Groene Valleilint}

Het Groene Valleilint kenmerkt zich als een gebied waar een mix van ecosystemen aanwezig is en waar nog enige uitbreiding van met name (half)natuurlijke graslanden wordt nagestreefd. Tevens liggen er in en om het gebied veel gebieden waar nieuwe natuurontwikkeling wordt nagestreefd (Figuur 12). In het gebied spelen met name knelpunten rond verdroging en vermesting (Figuur 13). Ook laat de intactness zien dat het gebied nog onvoldoende robuust is (Figuur 12). De deskundigen dragen twee strategieën aan om een verdere winst voor de biodiversiteit te realiseren in dit gebied. De eerste strategie vergt het creëren van lokale robuuste kernen met een stabiliserend effect op de overige omringende kleinere natuurgebieden. De tweede strategie betreft het verlagen van de druk vanuit het tussenliggende agrarische gebied door natuurinclusieve landbouw te stimuleren. Tevens dient er bij de ontwikkeling van het Groene Valleilint aandacht te zijn voor de verbinding met natuurgebieden in Utrecht.

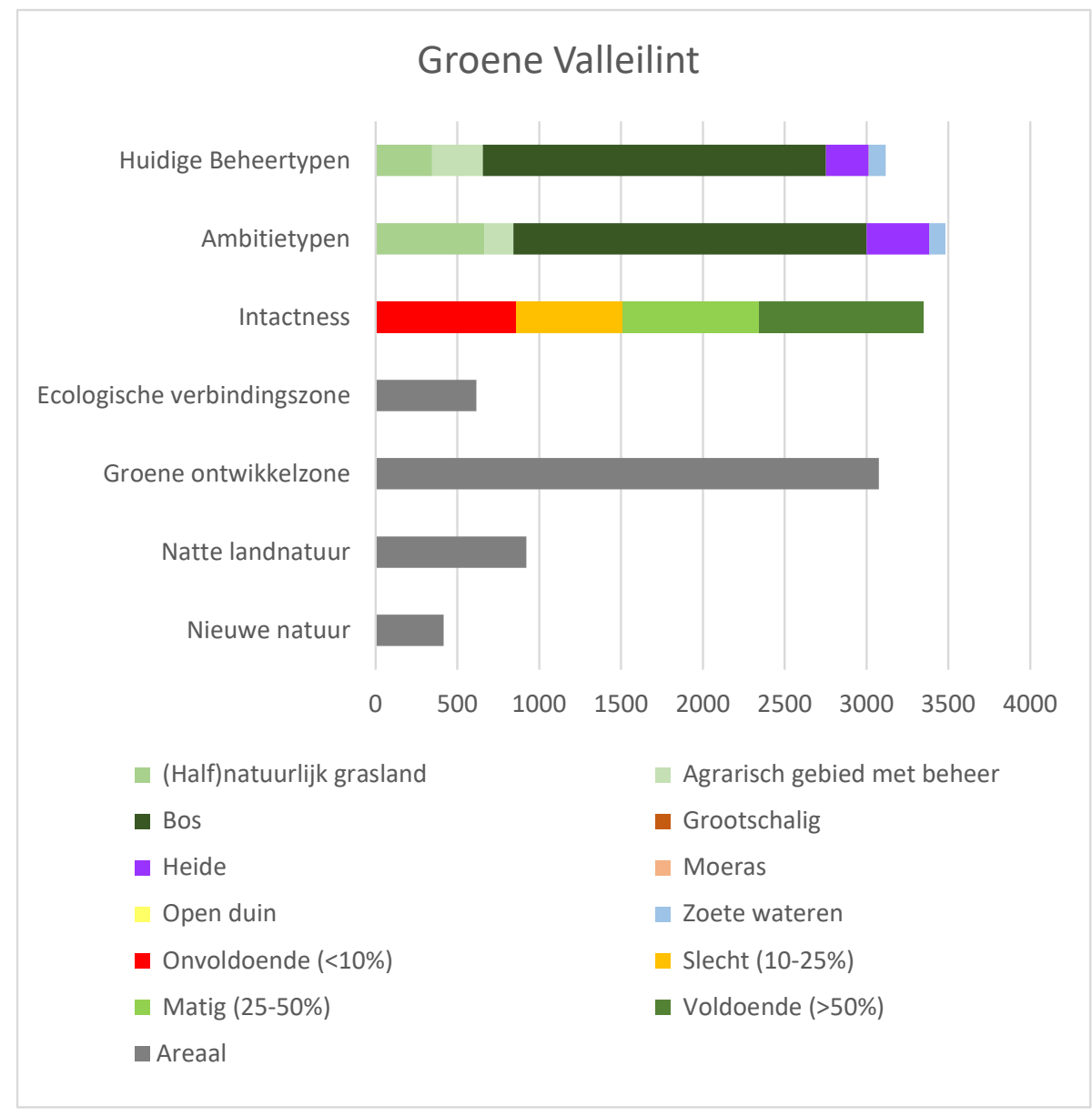

Figuur 12 Kenschets van het Groene Valleilint. (Zie 4.7 voor uitleg figuur.) De eenheid van de $x$-as is ha. 


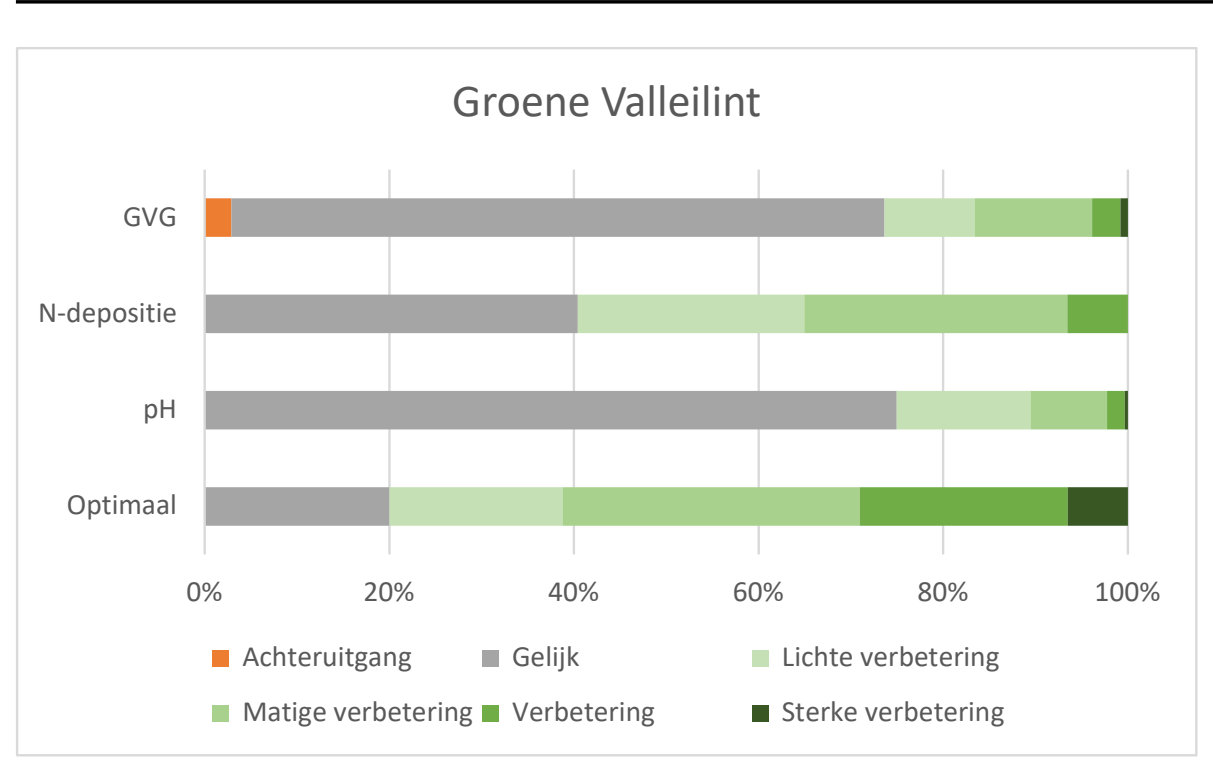

Figuur 13 MNP-resultaten m.b.t. verdroging (GVG), vermesting ( $N$-depositie) en verzuring $(p H)$ voor het Groene Valleilint. De staafdiagrammen geven het percentage van het areaal weer waar winst voor de biodiversiteit te realiseren is wanneer een van deze VER-thema's opgelost wordt en wanneer ze allemaal opgelost worden (Optimaal). 


\subsubsection{Binnenveld}

Het Binnenveld is een natuurgebied waar met name de (half)natuurlijke graslanden worden nagestreefd. De Ambitiekaart laat zien dat het areaal aan (half)natuurlijke graslanden met $50 \%$ zal toenemen. Tevens liggen er in en om het gebied enkele gebieden waar nieuwe natuurontwikkeling wordt nagestreefd (Figuur 14). In het gebied speelt met name het knelpunt rond verdroging (Figuur 15). Ook laat de intactness zien dat het gebied nog geïsoleerd ligt en onvoldoende robuust is (Figuur 14). De deskundigen bevestigen dat verdroging waarschijnlijk het grootste knelpunt is van het Binnenveld. Het gebied ligt ingeklemd tussen intensieve landbouw en zich uitbreidend stedelijk gebied. De inschatting is dat er fundamentele maatregelen op landschapsschaal nodig zijn om een gezond functionerend en robuust systeem te realiseren.

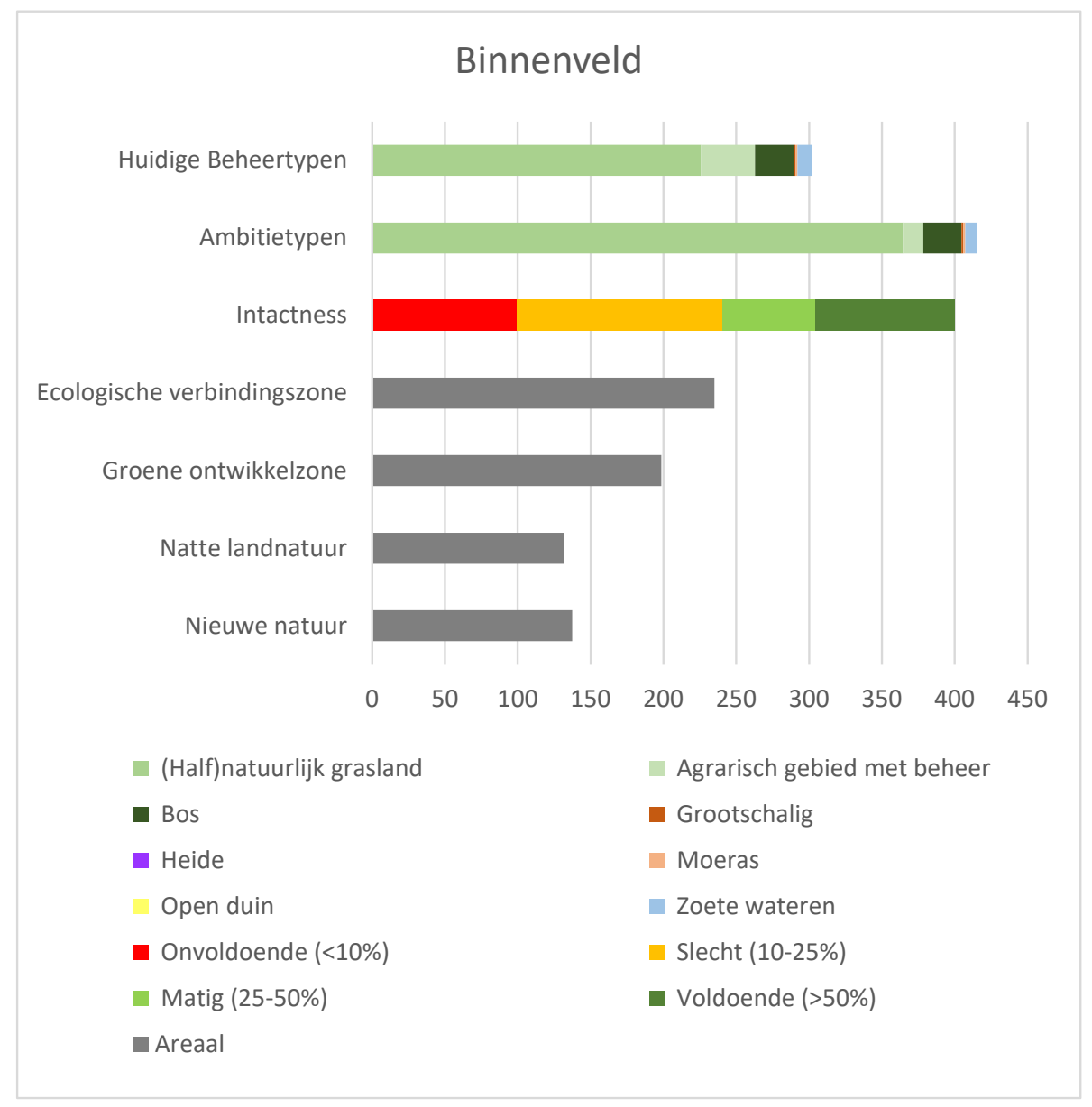

Figuur 14 Kenschets van het Binnenveld. (Zie 4.7 voor uitleg figuur.) De eenheid van de $x$-as is ha. 


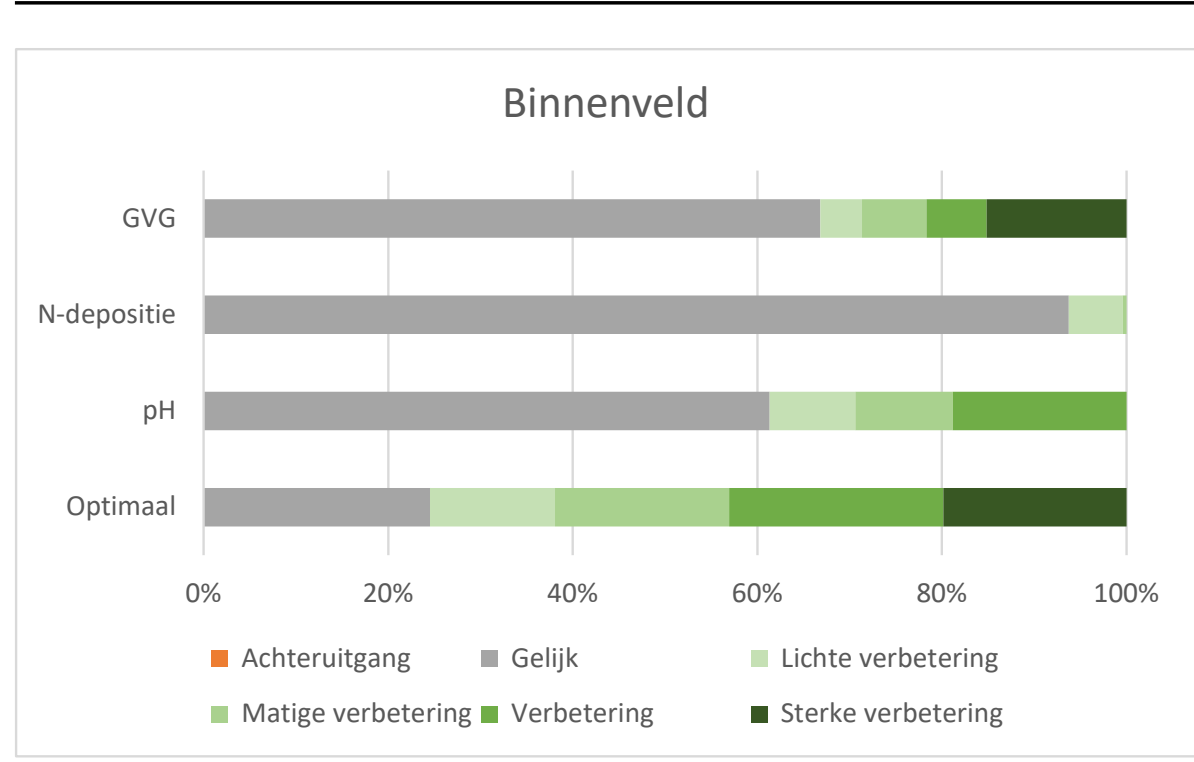

Figuur 15 MNP-resultaten m.b.t. verdroging (GVG), vermesting ( $N$-depositie) en verzuring $(\mathrm{pH})$ voor het Binnenveld. De staafdiagrammen geven het percentage van het areaal weer waar biodiversiteitswinst te realiseren is wanneer een van deze VER-thema's opgelost wordt en wanneer ze allemaal opgelost worden (Optimaal). 


\subsubsection{Linge(dijk)}

De Linge(dijk) is een gebied waar met name de (half)natuurlijke graslanden en bosgebieden aanwezig zijn. Tevens liggen er in en om het gebied enkele gebieden waar nieuwe natuurontwikkeling wordt nagestreefd (Figuur 16). In het gebied speelt met name het knelpunt rond verdroging. Het oplossen van de combinatie van de drukfactoren zorgt voor zeer veel biodiversiteitswinst (Figuur 17). De Linge(dijk) bestaat uit veel kleine geïsoleerde gebieden en is als geheel onvoldoende robuust (Figuur 16). De deskundigen bevestigen dat verdroging mogelijk een probleem is voor de aanwezige (half)natuurlijke graslanden, omdat rond de Lingedijk gebieden zijn opgehoogd ten behoeve van recreatie. Het streefpeilplan van de Linge is goed.

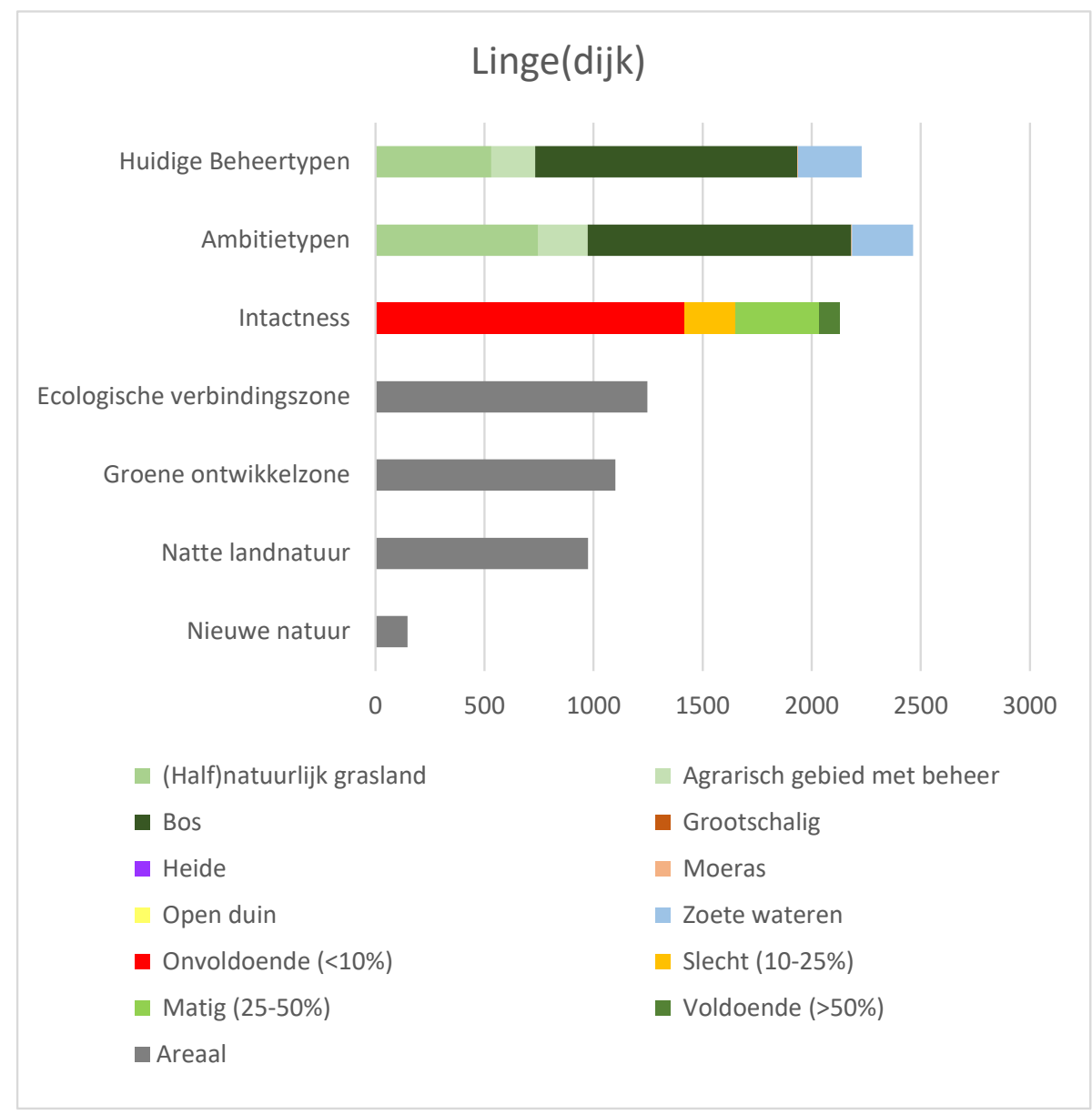

Figuur 16 Kenschets van de Linge(dijk). (Zie 4.7 voor uitleg figuur.) De eenheid van de $x$-as is ha. 


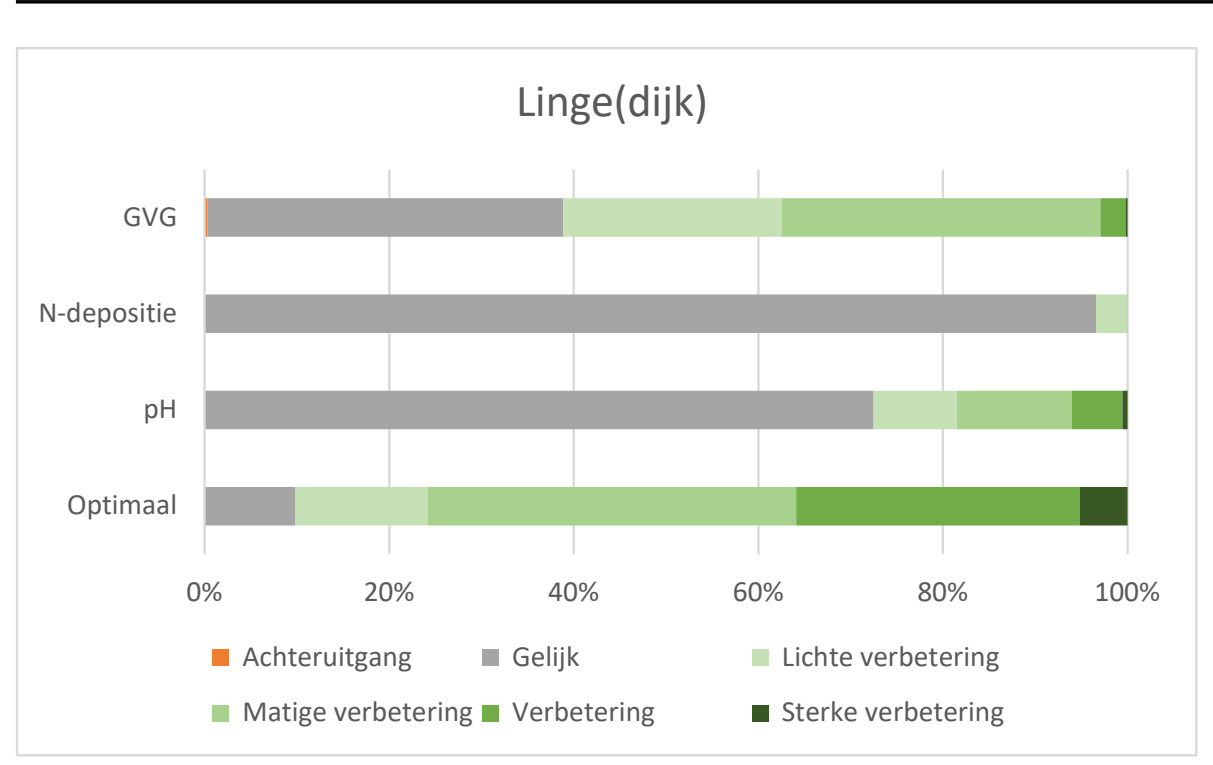

Figuur 17 MNP-resultaten m.b.t. verdroging (GVG), vermesting ( $N$-depositie) en verzuring $(\mathrm{pH})$ voor de Linge(dijk). De staafdiagrammen geven het percentage van het areaal weer waar biodiversiteitswinst te realiseren is wanneer een van deze VER-thema's opgelost wordt en wanneer ze allemaal opgelost worden (Optimaal). 


\subsubsection{Rivierengebied}

Het Rivierengebied tussen Ewijk en slot Loevestein is een gebied waar met name (half)natuurlijke graslanden, bosgebieden en zoet water aanwezig zijn. Tevens liggen er met name gebieden binnen de Groene ontwikkelzone in dit deel van het Rivierengebied (Figuur 18). De resultaten van de MNP geven aan dat er met name problemen spelen rond verzuring, maar deze resultaten worden niet bevestigd door de deskundigen (Figuur 19). De deskundigen geven aan dat veranderingen in de hoeveelheid kwel lokaal een knelpunt kan zijn. De intactness laat zien dat delen van het gebied onvoldoende robuust zijn (Figuur 18). In delen van het rivierengebied zouden hogere ambities qua natuur nagestreefd kunnen worden. Met name de monding van beken lijkt geschikt om meer moerasnatuur na te streven volgens de deskundigen (zie ook 4.5).

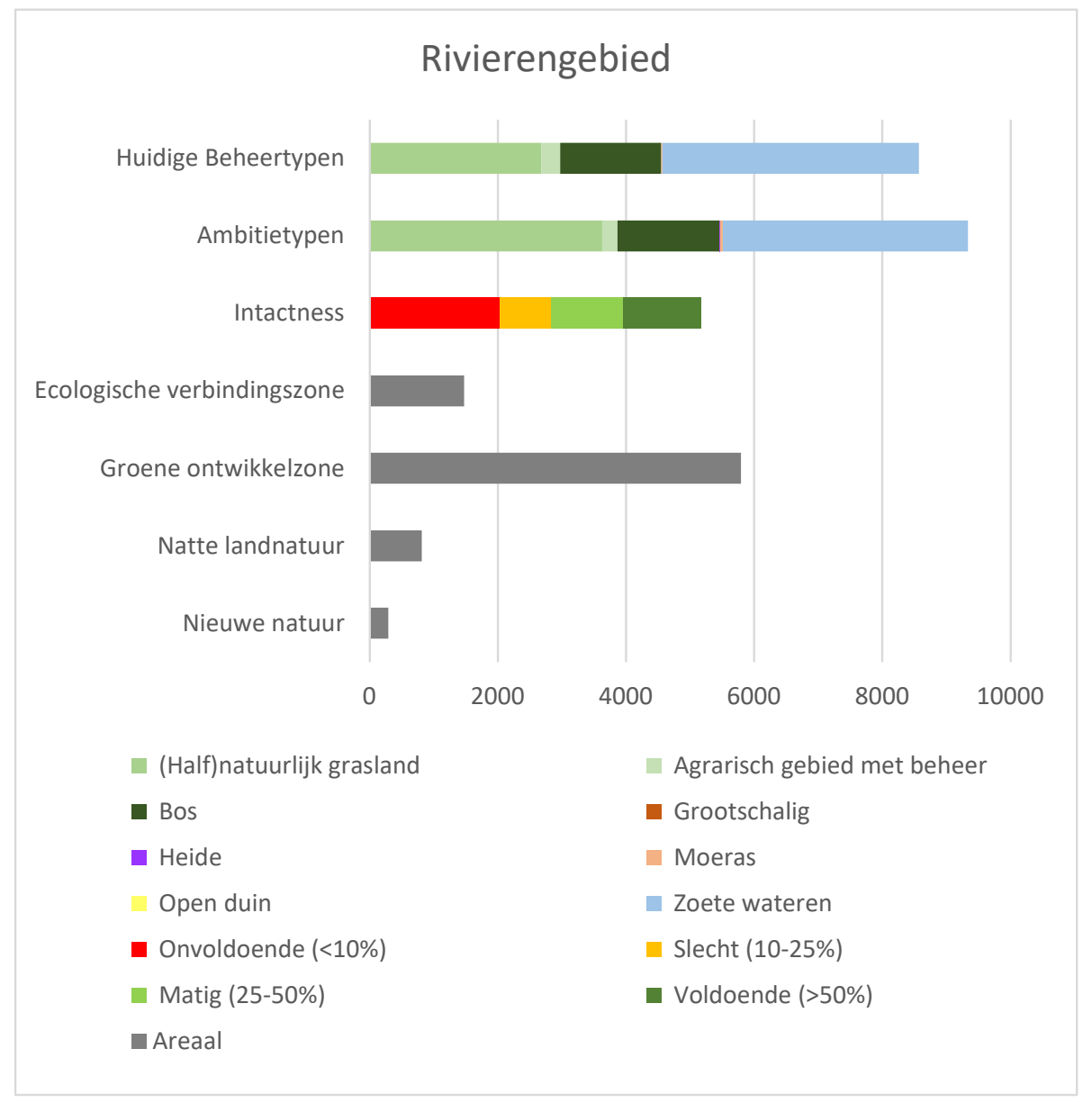

Figuur 18 Kenschets van het Rivierengebied. (Zie 4.7 voor uitleg figuur.) De eenheid van de $x$-as is ha. 


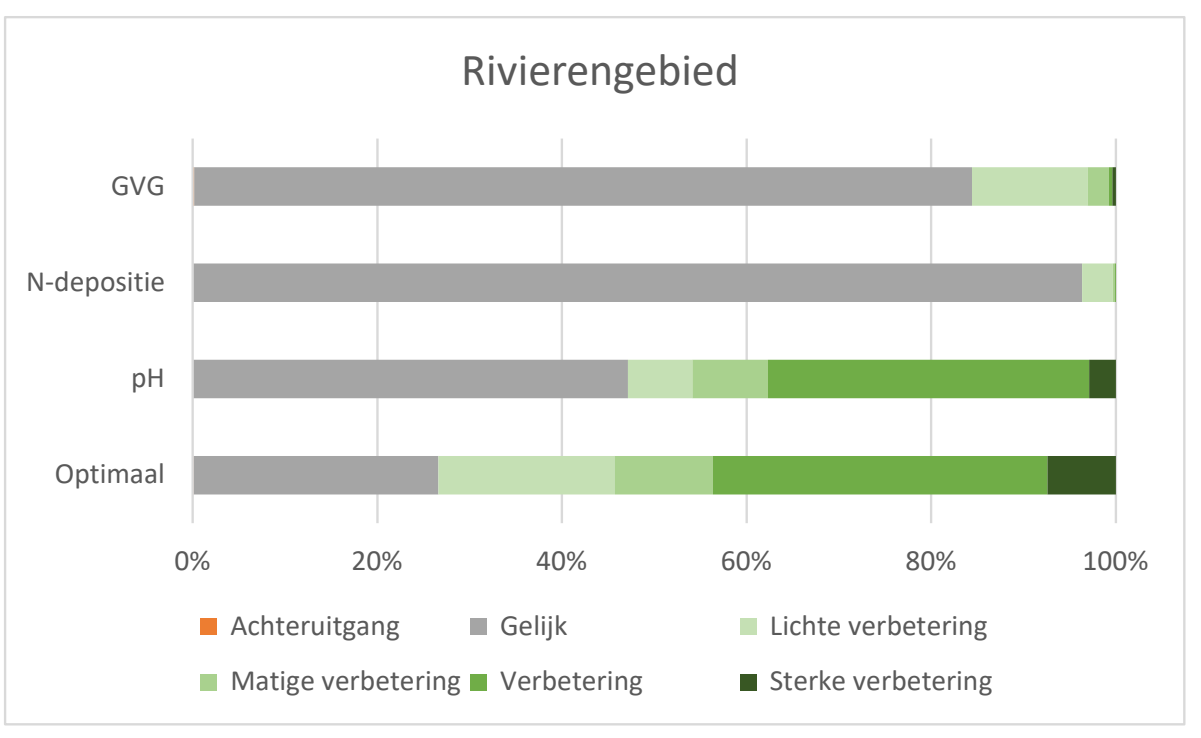

Figuur 19 MNP-resultaten m.b.t. verdroging (GVG), vermesting ( $N$-depositie) en verzuring $(\mathrm{pH})$ voor het Rivierengebied. De staafdiagrammen geven het percentage van het areaal weer waar biodiversiteitswinst te realiseren is wanneer een van deze VER-thema's opgelost wordt en wanneer ze allemaal opgelost worden (Optimaal). Door de deskundigen is aangegeven dat de resultaten met betrekking tot verzuring voor het Rivierengebied met voorzichtigheid moeten worden gehanteerd. 


\subsubsection{Hattem(erpoort)}

Hattem(erpoort) is een gebied waar met name een toename van (half)natuurlijke graslanden wordt nagestreefd. Er is een groot areaal als Groene ontwikkelzone aangewezen (Figuur 20). Het MNP-model geeft aan dat er problemen zijn met verzuring en verdroging (Figuur 21). Het gebied is relatief robuust, aangezien slechts een klein deel wordt beoordeeld als 'slecht' of 'onvoldoende' (Figuur 20). De deskundigen onderschrijven de verdrogingsproblematiek.

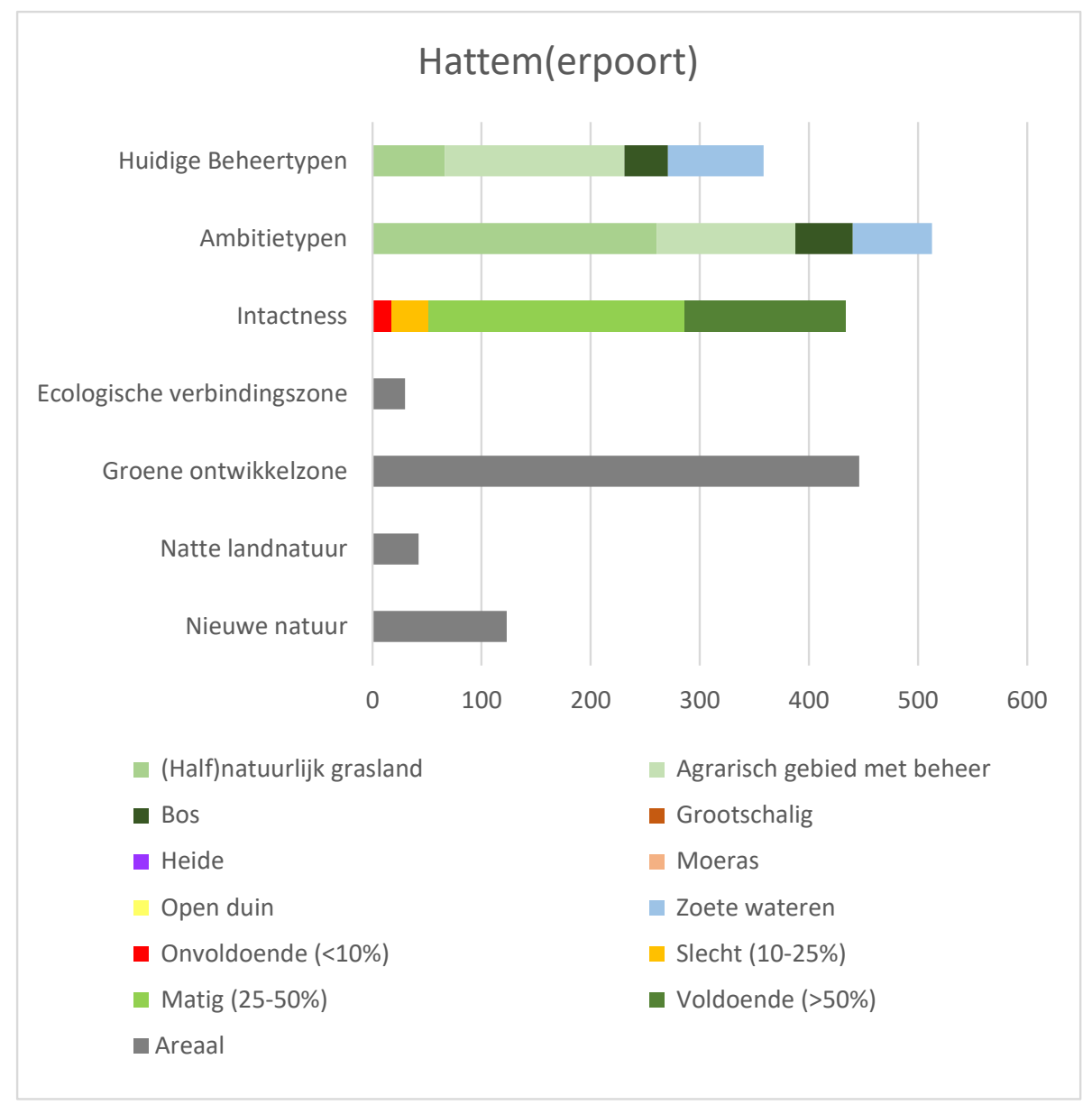

Figuur 20 Kenschets van Hattem(erpoort). (Zie 4.7 voor uitleg figuur.) De eenheid van de $x$-as is ha. 


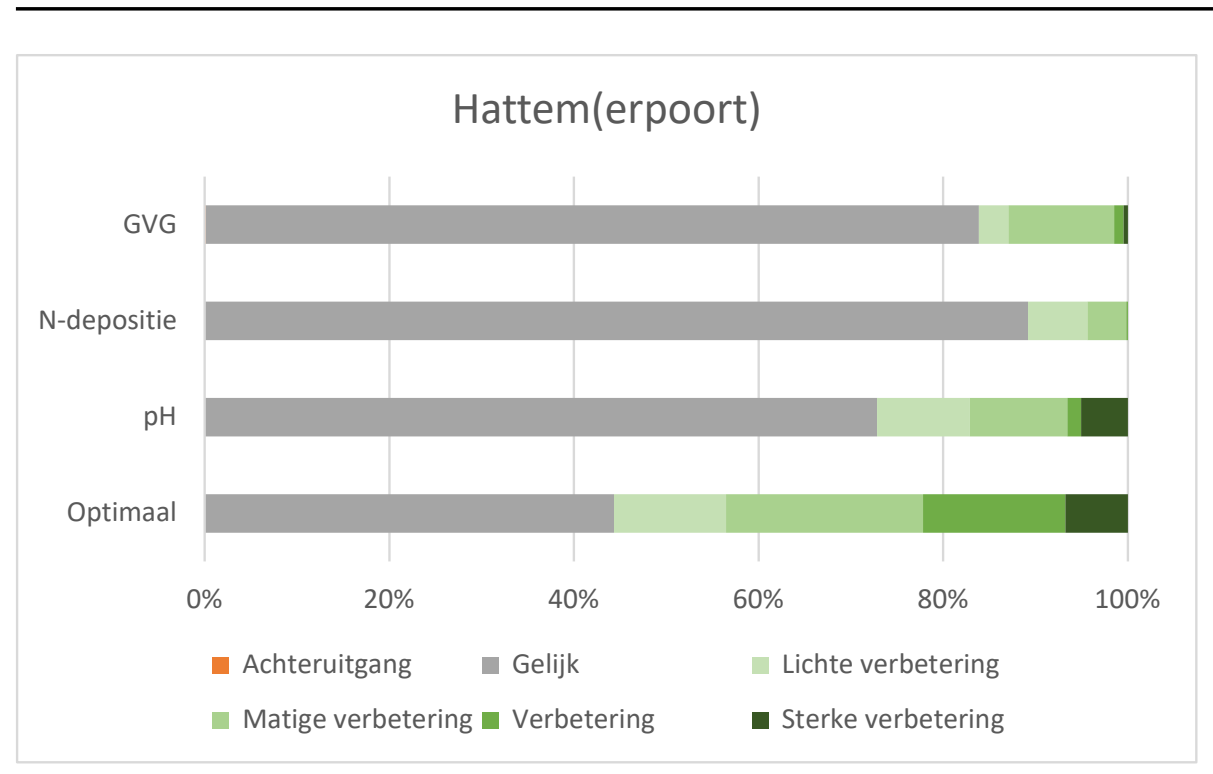

Figuur 21 MNP-resultaten m.b.t. verdroging (GVG), vermesting ( $N$-depositie) en verzuring $(\mathrm{pH})$ voor Hattem(erpoort). De staafdiagrammen geven het percentage van het areaal weer waar biodiversiteitswinst te realiseren is wanneer een van deze VER-thema's opgelost wordt en wanneer ze allemaal opgelost worden (Optimaal). 


\subsubsection{Beken en sprengen IJsselvallei}

Het stelsel van beken en sprengen van de IJsselvallei is een gebied waar vooral de aquatische natuurwaarden en overgangen naar terrestrische systemen waardevol zijn. Er liggen met name arealen binnen de Groene ontwikkelzone en Ecologische verbindingszones (Figuur 22). De resultaten van het MNP-model geven aan dat er nog enkele problemen spelen rond verdroging, vermesting en verzuring en dat het gecombineerd oplossen van deze knelpunten gunstig is voor de biodiversiteit (Figuur 23). Het gebied is te veel versnipperd en is daardoor onvoldoende robuust (Figuur 22). De deskundigen geven aan dat een van de specifieke knelpunten voor dit gebied de waterwinning is. Het gebied kenmerkt zich ook door belangrijke aquatische natuurwaarden, welke niet meegenomen worden met de MNP. Door aquatische experts dient aangegeven te worden welke maatregelen nodig zijn voor het behoud en herstel van deze natuurwaarden.

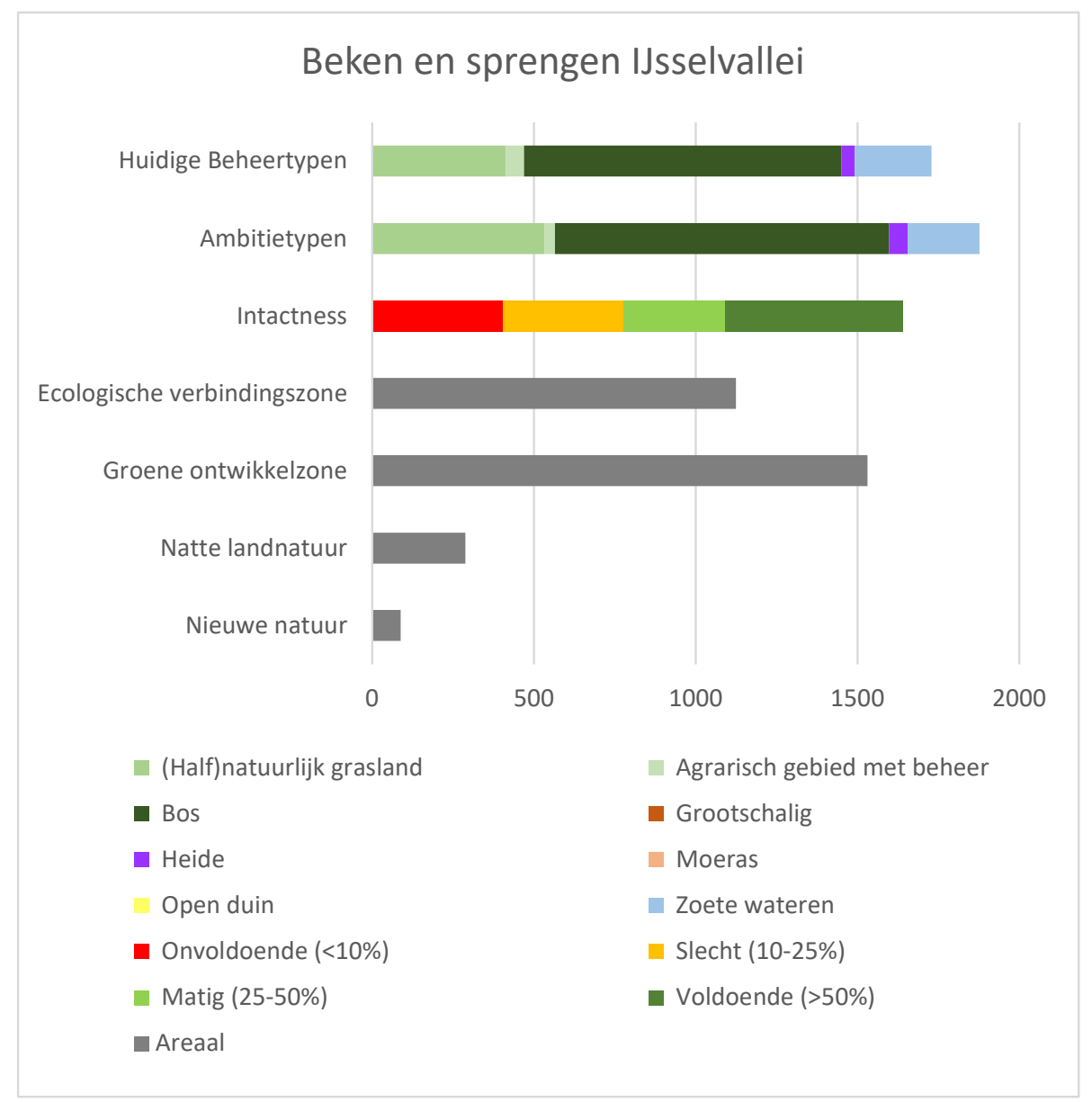

Figuur 22 Kenschets van de beken en sprengen in de IJsselvallei. (Zie 4.7 voor uitleg figuur.) De eenheid van de $x$-as is ha. 


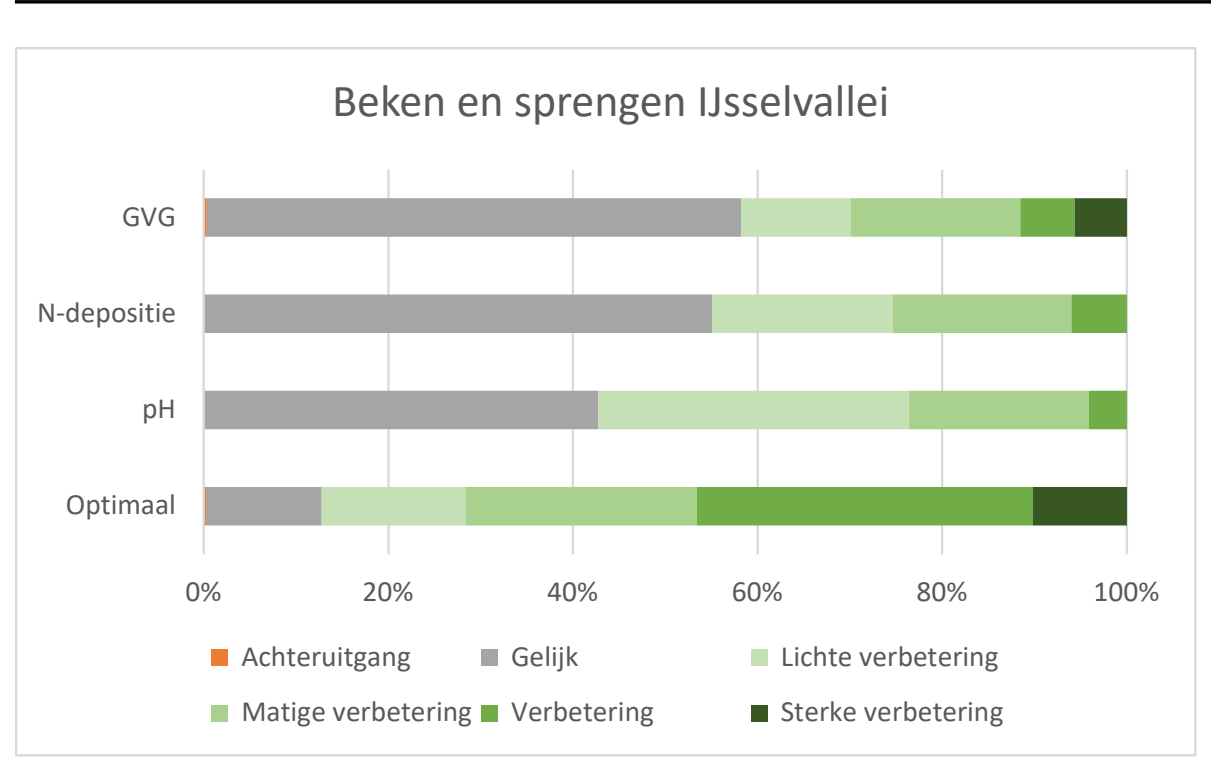

Figuur 23 MNP-resultaten m.b.t. verdroging (GVG), vermesting ( $N$-depositie) en verzuring $(p H)$ voor de beken en sprengen in de IJsselvallei. De staafdiagrammen geven het percentage van het areaal weer waar winst voor de biodiversiteit te realiseren is wanneer een van deze VER-thema's opgelost wordt en wanneer ze allemaal opgelost worden (Optimaal). 


\subsubsection{Landgoederen Veluwe-IJssel/Zutphen}

De Landgoederen Veluwe-IJssel/Zutphen is een gebied waar bosgebieden afgewisseld worden met (half)natuurlijke graslanden, zoet water en agrarische functies. Er liggen vooral gebieden binnen de Groene ontwikkelzone (Figuur 24). De resultaten van het MNP-model geven aan dat er enkele verdrogings-, vermestings- en verzuringproblemen zijn en dat met name het gecombineerd oplossen van deze knelpunten biodiversiteitswinst kan opleveren (Figuur 25). Ook laat de intactness zien dat delen van het gebied onvoldoende robuust zijn (Figuur 24). Mogelijk dat in dit gebied de combinatie van de strategieën van lokale robuuste kernen en natuurinclusieve landbouw leidt tot het realiseren van de potentiële biodiversiteitswinst.

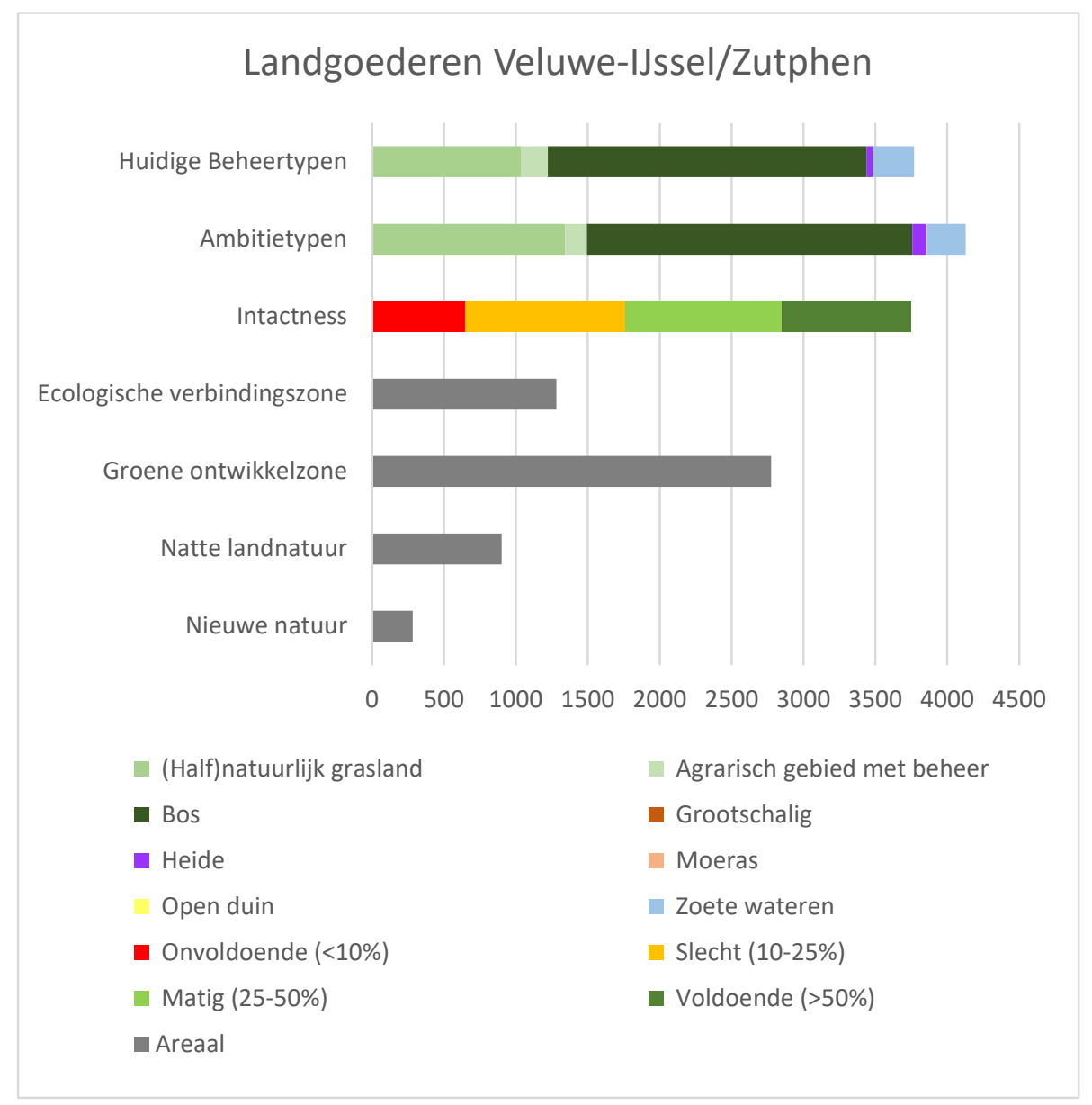

Figuur 24 Kenschets van de Landgoederen Veluwe-IJssel/Zutphen. (Zie 4.7 voor uitleg figuur.) De eenheid van de $x$-as is ha. 


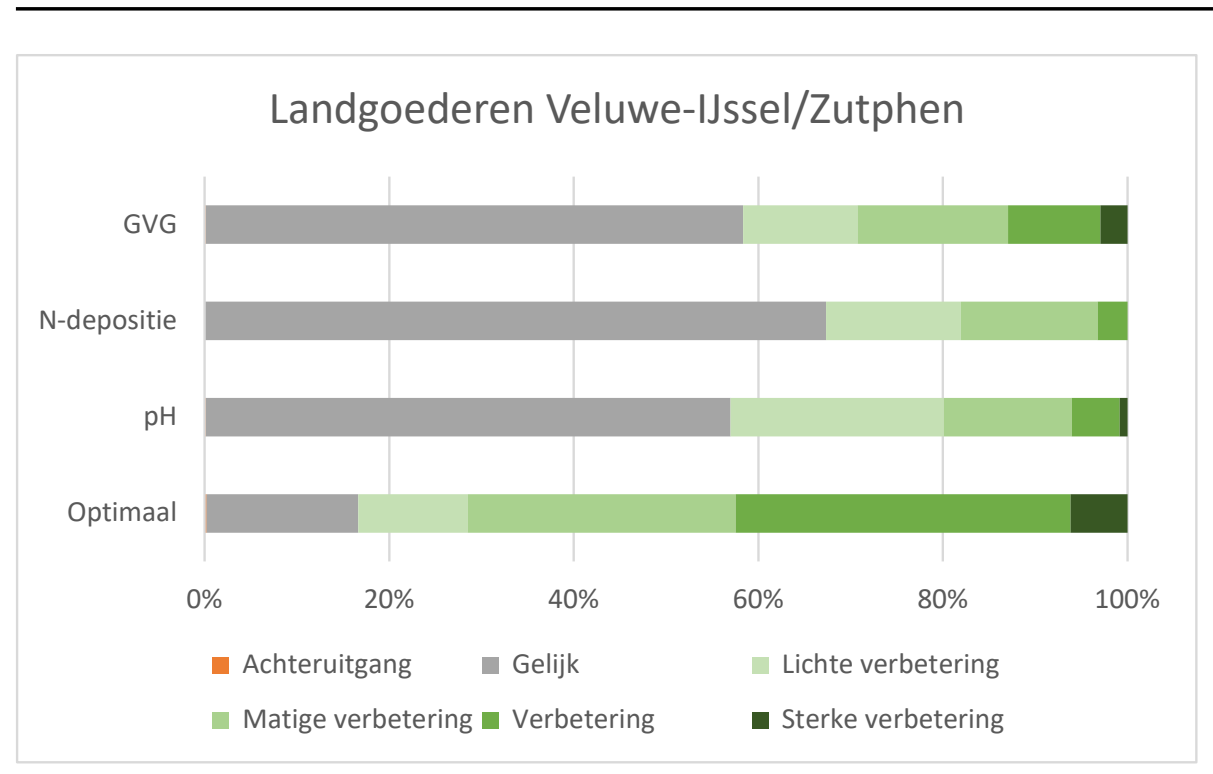

Figuur 25 MNP-resultaten m.b.t. verdroging (GVG), vermesting ( $N$-depositie) en verzuring $(\mathrm{pH})$ voor de Landgoederen Veluwe-IJssel/Zutphen. De staafdiagrammen geven het percentage van het areaal weer waar biodiversiteitswinst te realiseren is wanneer een van deze VER-thema's opgelost wordt en wanneer ze allemaal opgelost worden (Optimaal). 


\subsubsection{Grote Veld e.o.}

Grote Veld e.o. is een gebied waar met name bosgebieden aanwezig zijn. In het gebied liggen enkele delen van de Groene ontwikkelzone (Figuur 26). De resultaten van de MNP geven aan dat er met name problemen spelen rond vermesting (Figuur 27). De intactness laat zien dat het gebied relatief robuust is, aangezien slechts een klein deel wordt beoordeeld als 'slecht' of 'onvoldoende' (Figuur 26).

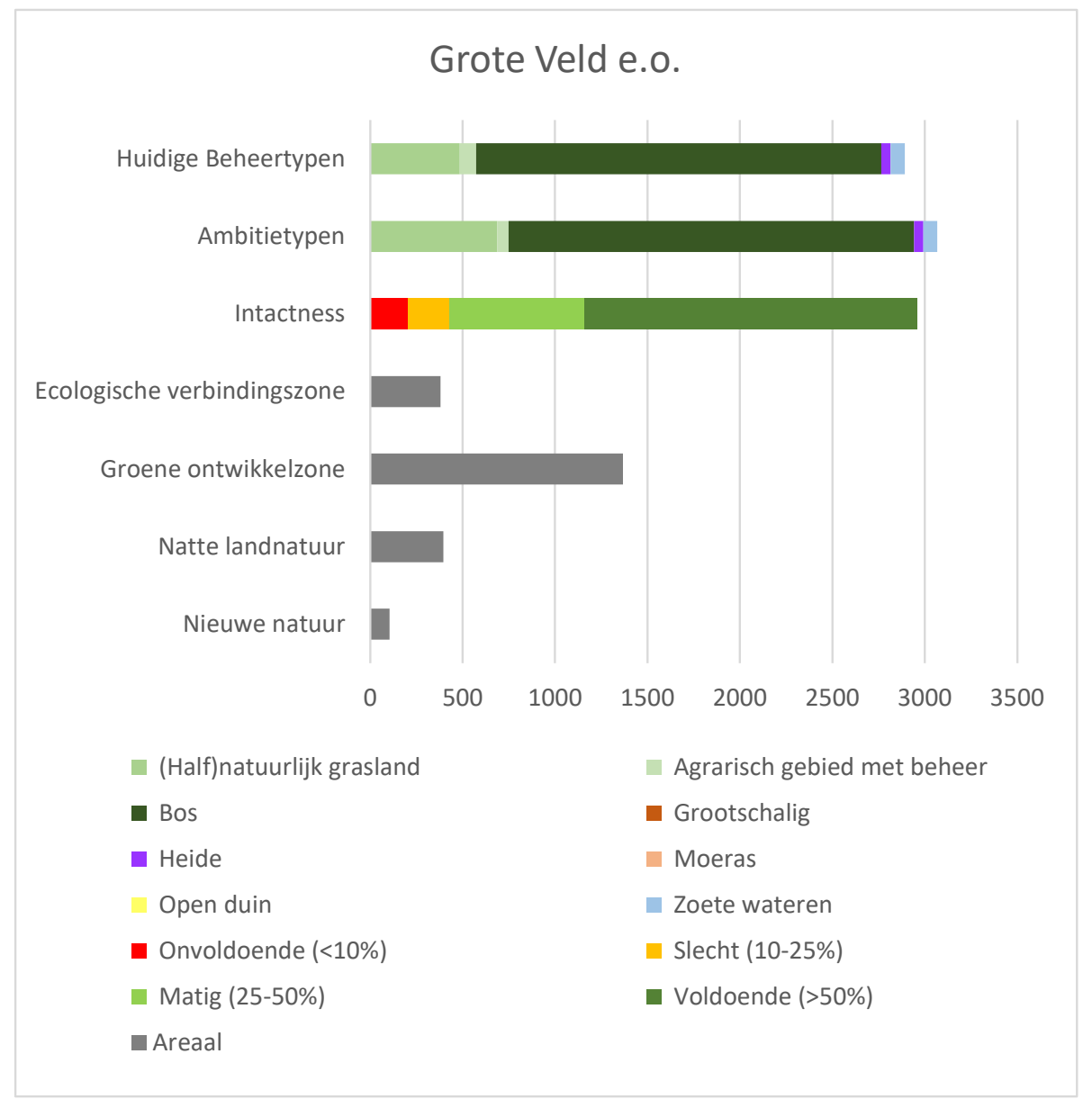

Figuur 26 Kenschets van Grote Veld e.o. (Zie 4.7 voor uitleg figuur.) De eenheid van de $x$-as is ha. 


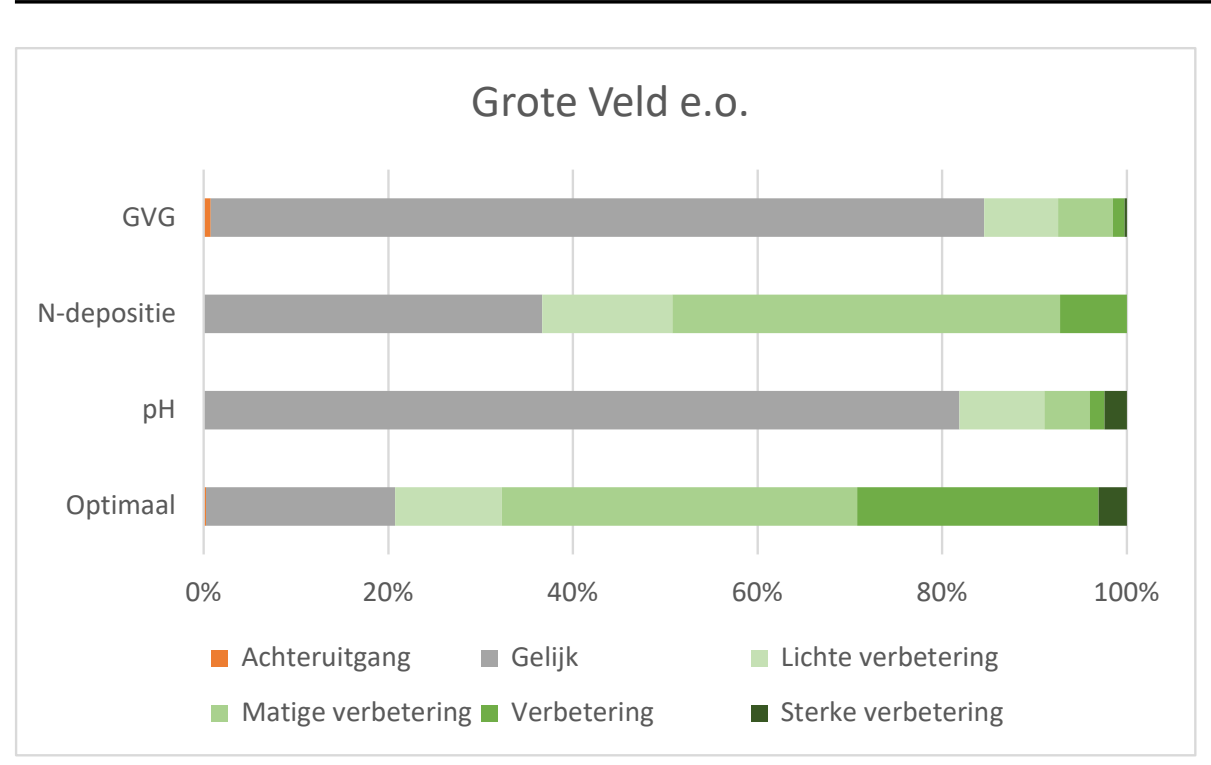

Figuur 27 MNP-resultaten m.b.t. verdroging (GVG), vermesting ( $N$-depositie) en verzuring $(\mathrm{pH})$ voor Grote Veld e.o. De staafdiagrammen geven het percentage van het areaal weer waar biodiversiteitswinst te realiseren is wanneer een van deze VER-thema's opgelost wordt en wanneer ze allemaal opgelost worden (Optimaal). 


\subsubsection{Baakse beek e.o.}

De Baakse beek e.o. is een gebied waar met name bosgebieden aanwezig zijn rond het beekdal. Rond het gebied liggen ook gebieden in de Groene ontwikkelzone (Figuur 28). De resultaten van de MNP geven aan dat er met name problemen spelen rond verdroging en vermesting en dat het oplossen van beide factoren tot een toename in biodiversiteit zal leiden (Figuur 29). De intactness laat zien dat het gebied relatief robuust is, aangezien slechts een klein deel wordt beoordeeld als 'slecht' of 'onvoldoende' (Figuur 28). De deskundigen bevestigen dat een potentiële toename in biodiversiteit gerealiseerd kan worden in de Baakse beek e.o. Daarbij dient ook de ontsnippering van het watersysteem in acht genomen te worden. Voor de Baakse beek moet ook met aquatische experts nagegaan worden welke strategie gevolgd moet worden.

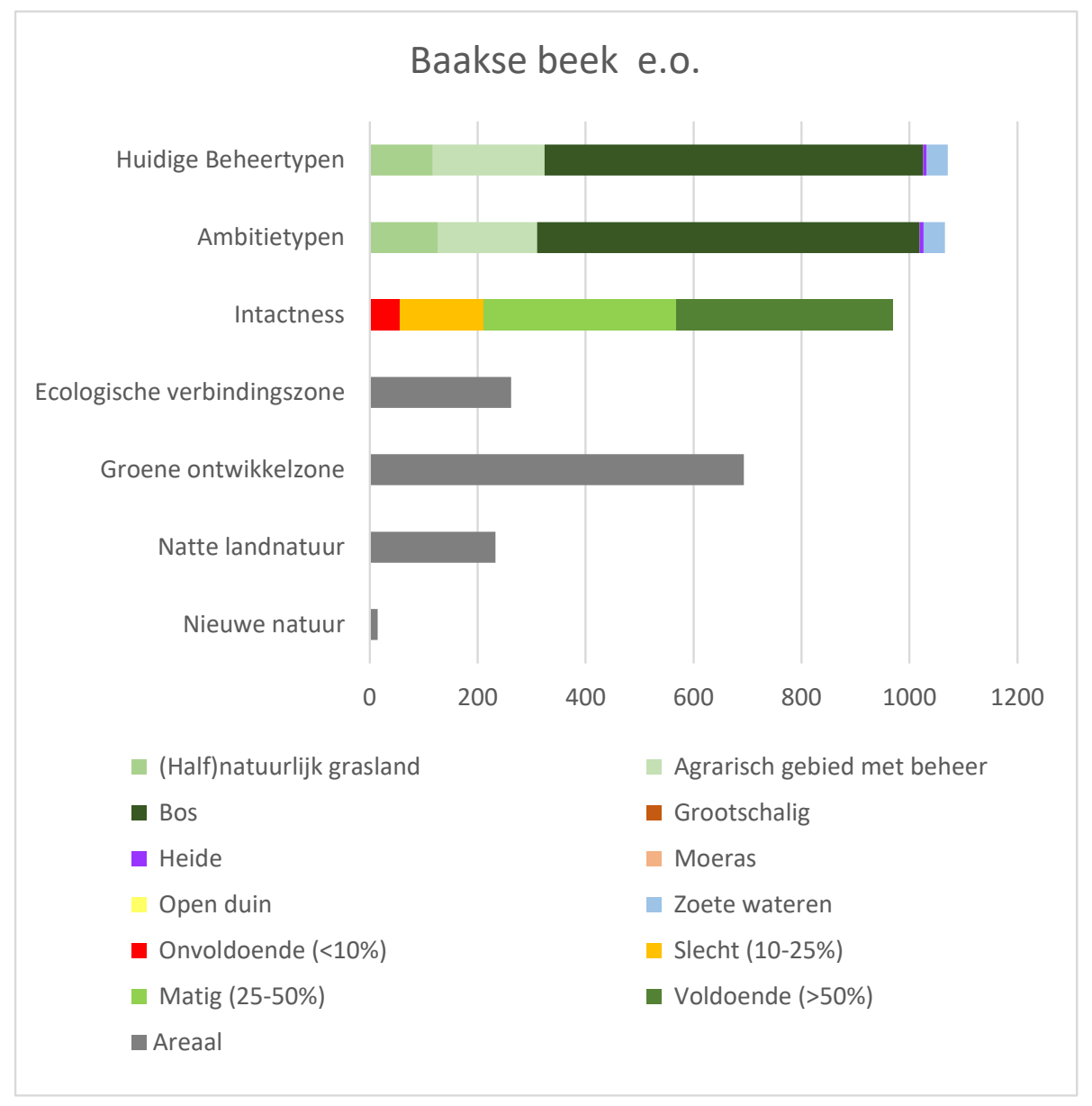

Figuur 28 Kenschets van de Baakse beek e.o. (Zie 4.7 voor uitleg figuur.) De eenheid van de $x$-as is ha. 


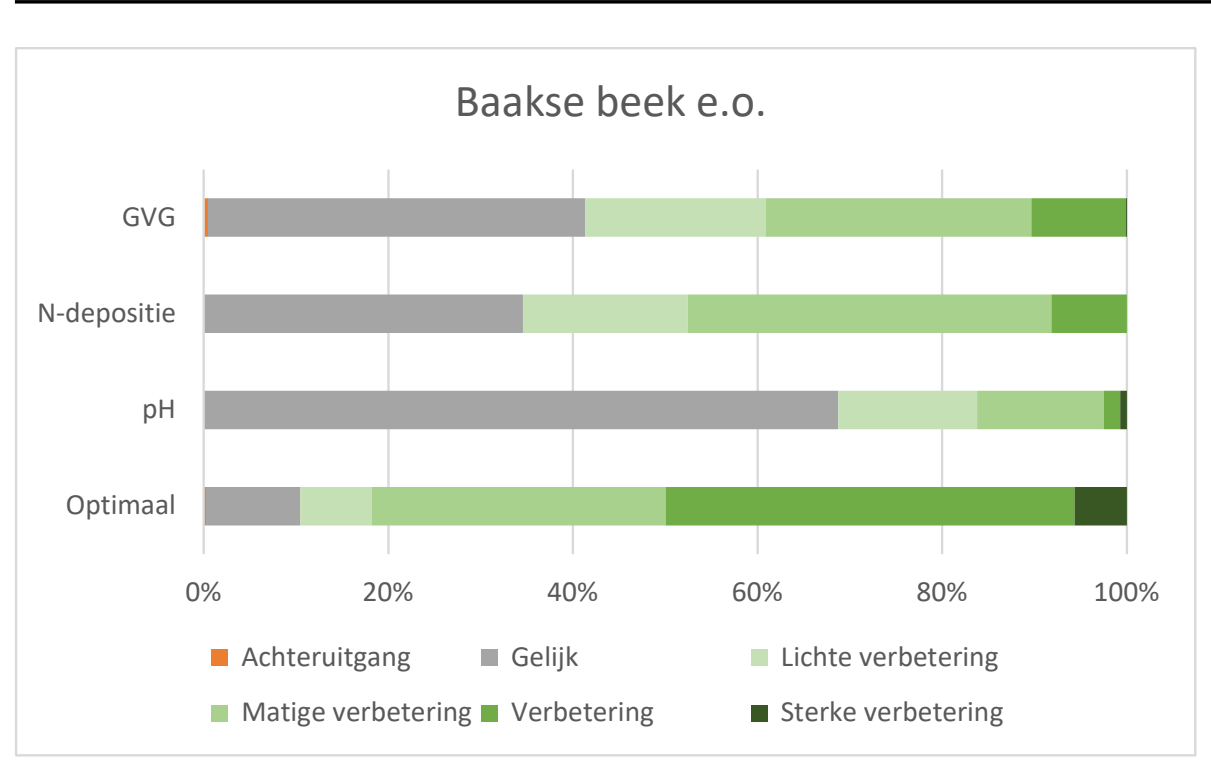

Figuur 29 MNP-resultaten m.b.t. verdroging (GVG), vermesting ( $N$-depositie) en verzuring $(\mathrm{pH})$ voor de Baakse beek e.o. De staafdiagrammen geven het percentage van het areaal weer waar biodiversiteitswinst te realiseren is wanneer een van deze VER-thema's opgelost wordt en wanneer ze allemaal opgelost worden (Optimaal). 


\subsubsection{Groote beek}

De Groote beek is een gebied waar met name veel kleine bosgebieden aanwezig zijn rond het beekdal. Rond het gebied liggen ook gebieden in de Groene ontwikkelzone en Ecologische verbindingszones (Figuur 30). De resultaten van de MNP geven aan dat er met name problemen spelen rond verdroging en verzuring en dat het oplossing van beide factoren tot een toename in biodiversiteit zal leiden (Figuur 31). De intactness laat zien dat het gebied bestaat uit allemaal kleine gebieden die niet robuust zijn. Het is vooral opvallend dat er meer areaal aan zoekgebieden aanwezig is dan reeds gerealiseerde natuur (Figuur 30). De deskundigen geven aan dat met aquatische experts nagegaan moet worden welke strategie gevolgd moet worden met betrekking tot de Groote beek.

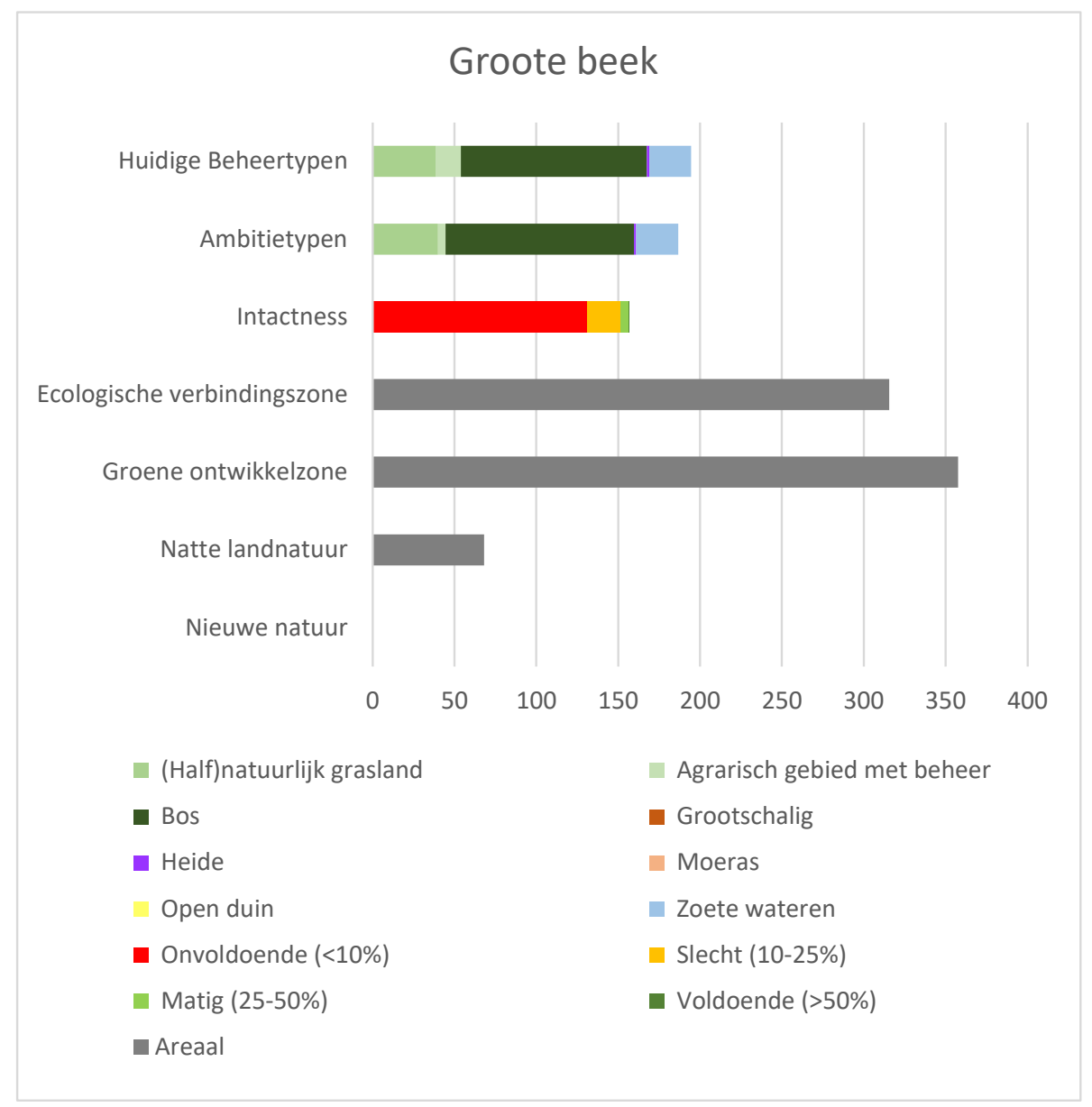

Figuur 30 Kenschets van de Groote beek. (Zie 4.7 voor uitleg figuur.) De eenheid van de $x$-as is ha. 


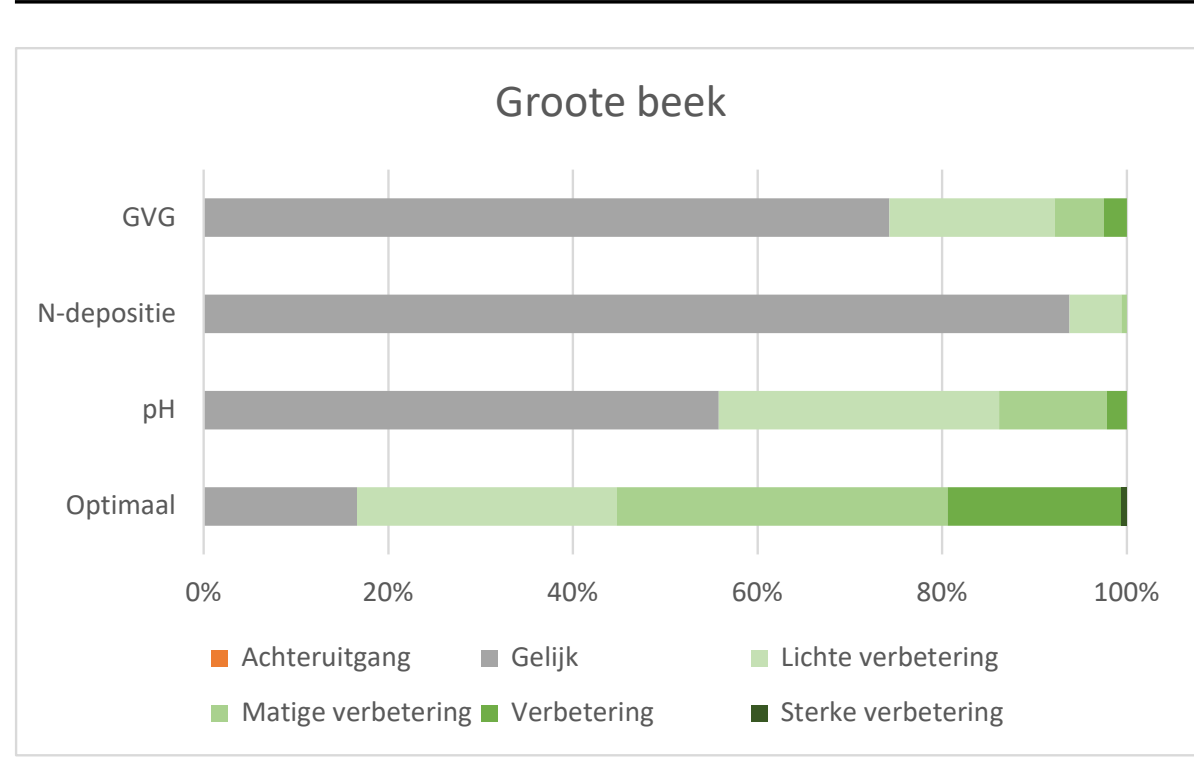

Figuur 31 MNP-resultaten m.b.t. verdroging (GVG), vermesting ( $N$-depositie) en verzuring $(\mathrm{pH})$ voor de Groote beek. De staafdiagrammen geven het percentage van het areaal weer waar biodiversiteitswinst te realiseren is wanneer een van deze VER-thema's opgelost wordt en wanneer ze allemaal opgelost worden (Optimaal). 


\subsubsection{Achterhoek}

Het centrale deel van de Achterhoek is een gebied waar met name veel kleine bosgebieden aanwezig zijn. In het gebied liggen ook gebieden in de Groene ontwikkelzone en Ecologische verbindingszones (Figuur 32). De resultaten van de MNP geven aan dat er met name problemen spelen rond vermesting, maar ook dat een gecombineerde oplossing van alle drukfactoren tot een toename in biodiversiteit zal leiden (Figuur 33). Ook verdroging speelt een rol in het gebied, maar door de impact van vermesting zal het alleen oplossen van verdroging tot een relatief lage winst leiden. De intactness laat zien dat het gebied bestaat uit allemaal kleine gebieden die niet robuust zijn. Het is vooral opvallend dat er meer areaal aan zoekgebieden aanwezig is dan reeds gerealiseerde natuur (Figuur 32). Door de deskundigen wordt aangegeven dat het met het huidige landbouwgebruik in de Achterhoek niet mogelijk is om in alle bosgebieden in het centrale deel van de Achterhoek een goede kwaliteit te realiseren. Een optie is om de ambities voor deze gebieden naar beneden bij te stellen. Oorspronkelijk kenmerkt het gebied zich door natte systemen, maar om deze systemen weer te realiseren, zal de oorspronkelijke sponswerking weer hersteld moeten worden voor de hele regio.

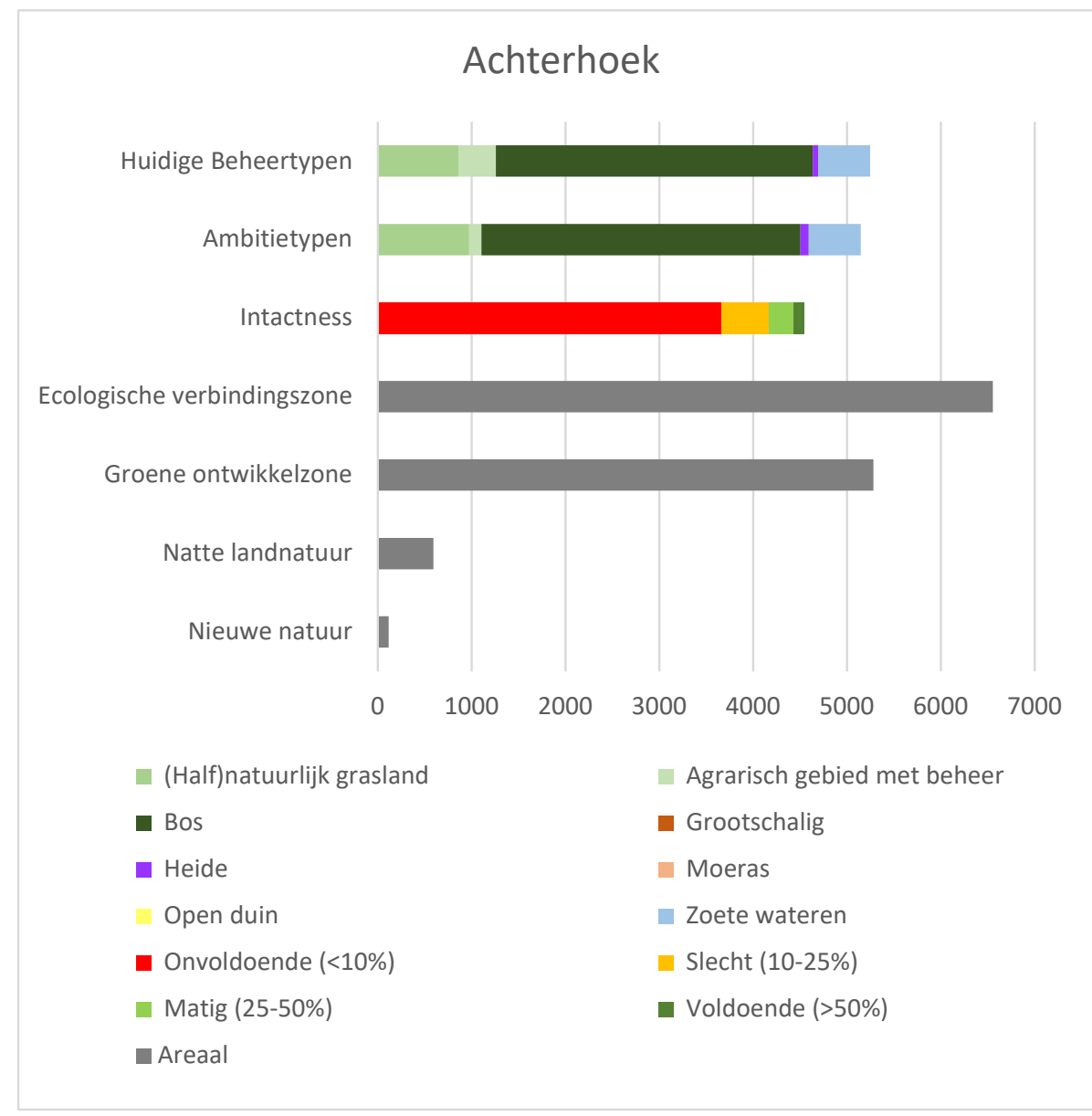

Figuur 32 Kenschets van de Achterhoek. (Zie 4.7 voor uitleg figuur.) De eenheid van de $x$-as is ha. 


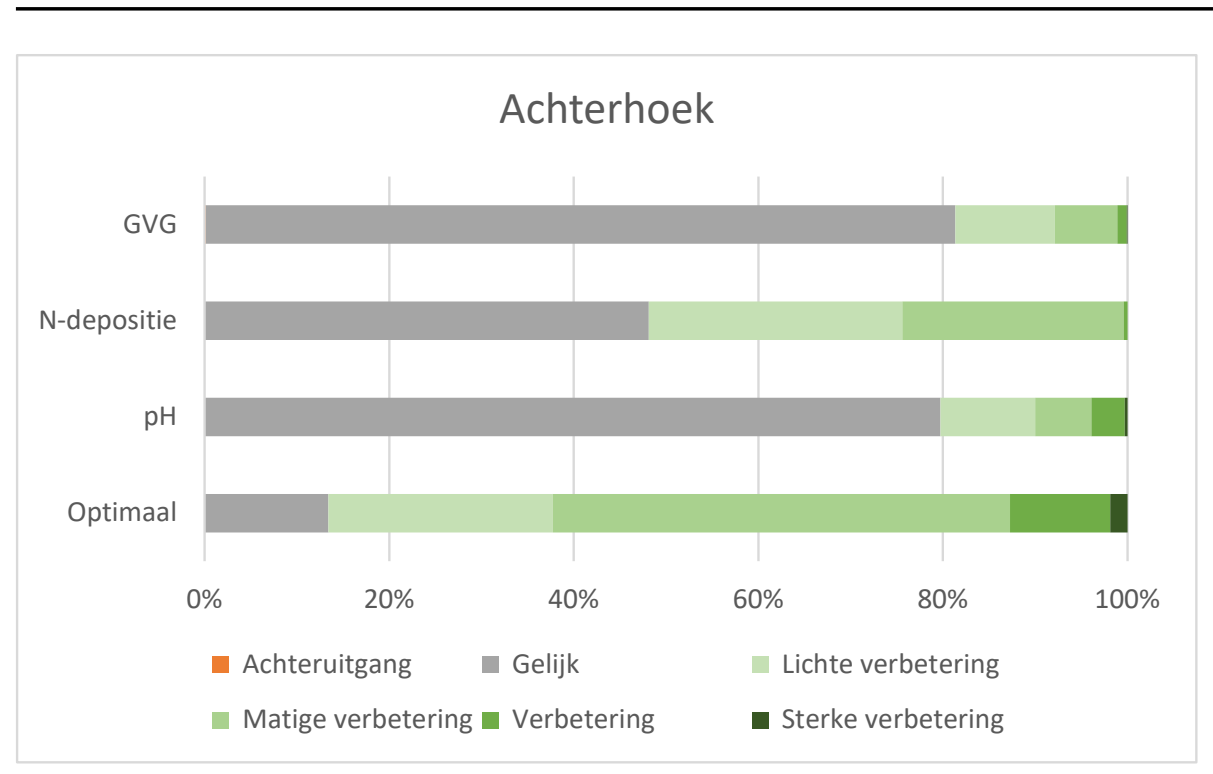

Figuur 33 MNP-resultaten m.b.t. verdroging (GVG), vermesting ( $N$-depositie) en verzuring $(\mathrm{pH})$ voor de Achterhoek. De staafdiagrammen geven het percentage van het areaal weer waar biodiversiteitswinst te realiseren is wanneer een van deze VER-thema's opgelost wordt en wanneer ze allemaal opgelost worden (Optimaal). 


\subsubsection{Winterswijk e.o.}

Winterswijk e.o. is een gebied dat bestaat uit een afwisseling van bosgebieden, kleinschalig landschap, beken en landbouw. In het gebied liggen ook gebieden in de Groene ontwikkelzone (Figuur 34). De resultaten van de MNP geven aan dat er met name problemen spelen rond verdroging en vermesting en dat een gecombineerde oplossing van alle drukfactoren tot een toename in biodiversiteit zal leiden (Figuur 35). De intactness laat zien dat het gebied bestaat uit allemaal kleine gebieden die niet robuust zijn (Figuur 34). Door de deskundigen wordt ingeschat dat het gebied kansen biedt voor biodiversiteitswinst wanneer natuurinclusieve landbouw wordt nagestreefd. Ook biedt het gebied kansen voor herstel van landschapselementen.

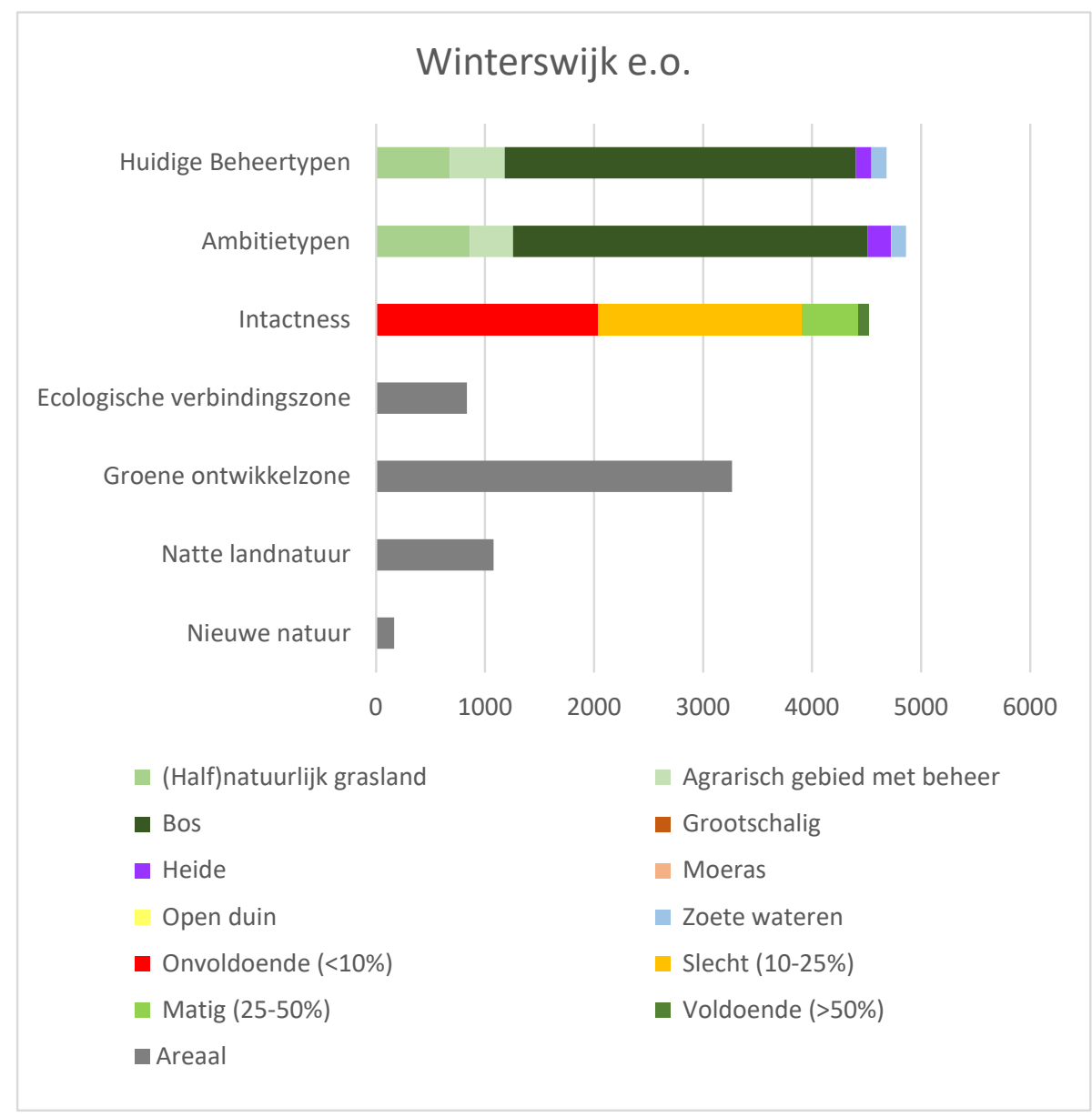

Figuur 34 Kenschets van Winterswijk e.o. (Zie 4.7 voor uitleg figuur.) De eenheid van de $x$-as is ha. 


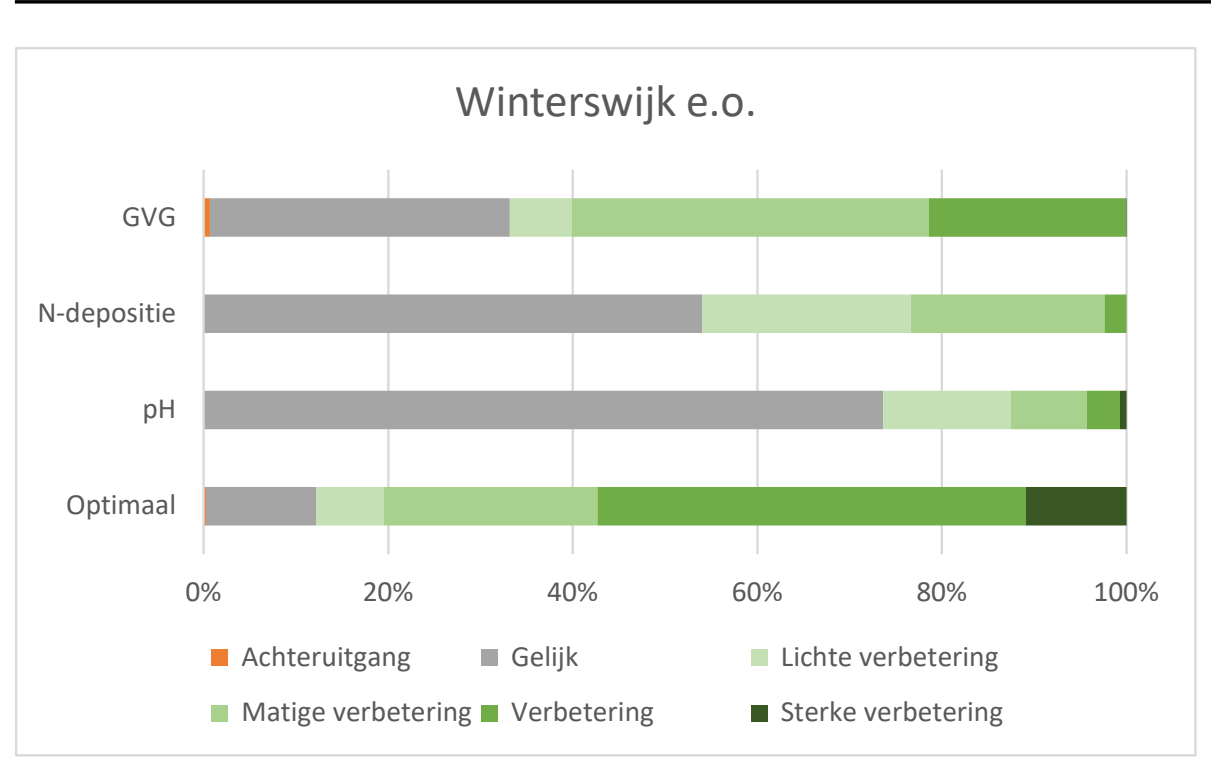

Figuur 35 MNP-resultaten m.b.t. verdroging (GVG), vermesting ( $N$-depositie) en verzuring $(\mathrm{pH})$ voor Winterswijk e.o. De staafdiagrammen geven het percentage van het areaal weer waar biodiversiteitswinst te realiseren is wanneer een van deze VER-thema's opgelost worden en wanneer ze allemaal opgelost worden (Optimaal). 


\subsubsection{Montferland}

Montferland is een groot aaneengesloten bosgebied. De intactness laat zien dat het qua grootte robuust is. In de omgeving van het gebied liggen enkele delen van de Groene ontwikkelzone (Figuur 36). De resultaten van de MNP geven aan dat er met name problemen spelen rond vermesting en verzuring, waarbij met name strategieën die de vermesting tegengaan tot een toename in biodiversiteit zal leiden (Figuur 37). Door de deskundigen is aangegeven dat in Montferland mogelijk lokaal problemen kunnen spelen met betrekking tot waterwinning, maar de inschatting is dat deze problemen minder groot zijn dan bij de sprengen en beken op de Veluwe.

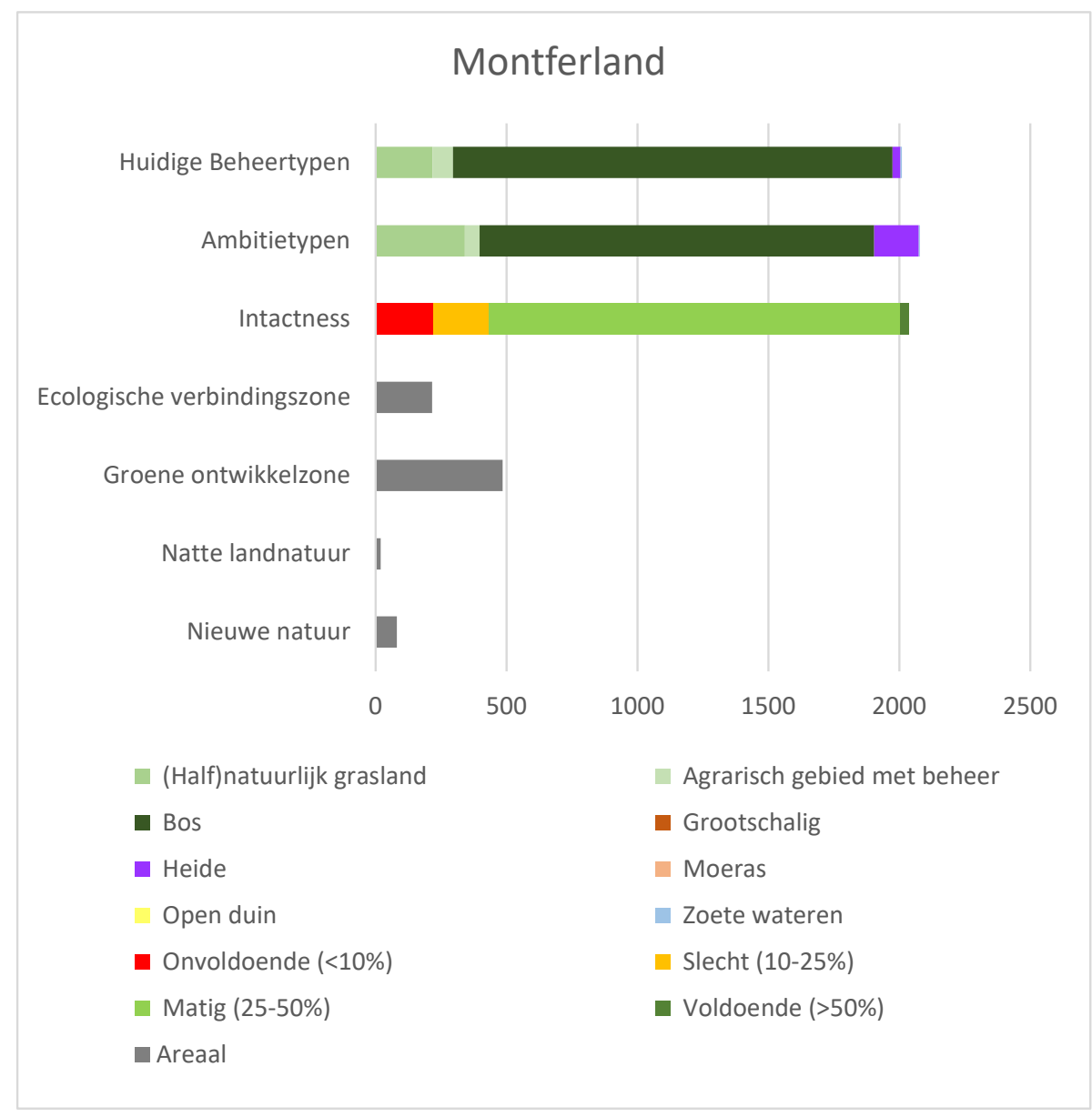

Figuur 36 Kenschets van Montferland. (Zie 4.7 voor uitleg figuur.) De eenheid van de $x$-as is ha. 


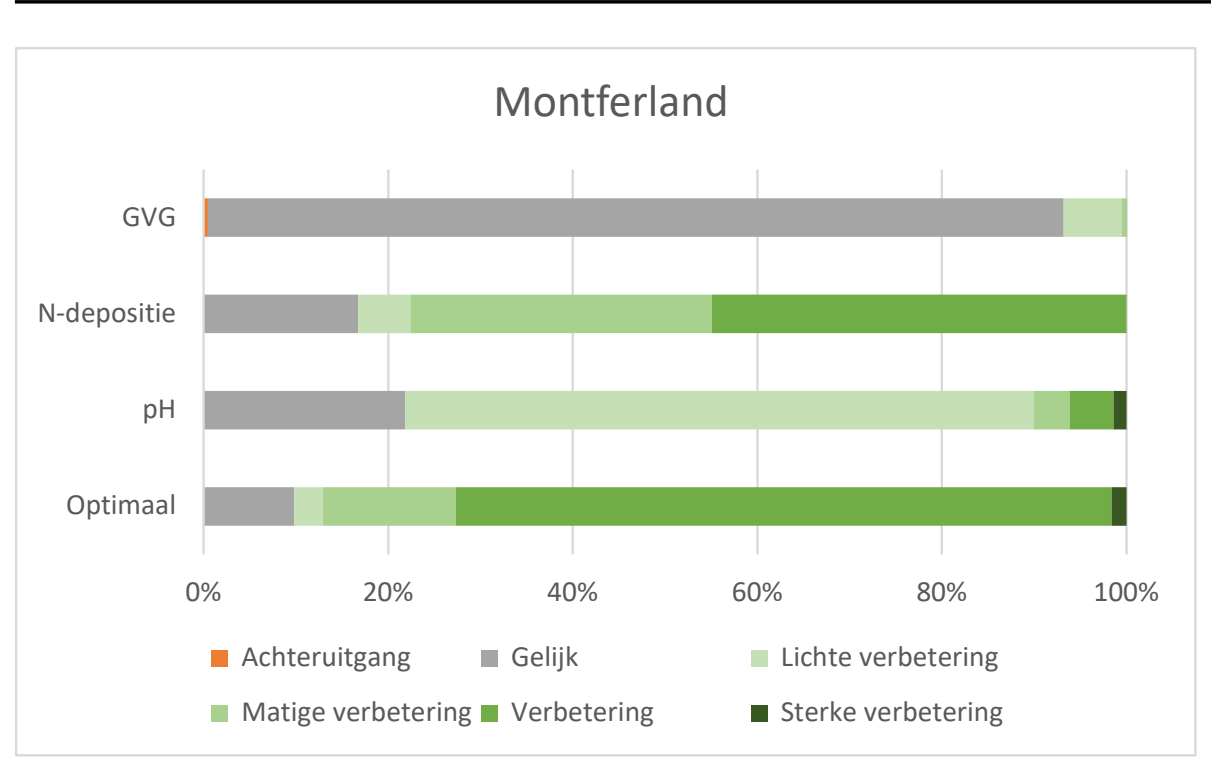

Figuur 37 MNP-resultaten m.b.t. verdroging (GVG), vermesting ( $N$-depositie) en verzuring $(\mathrm{pH})$ voor Montferland. De staafdiagrammen geven het percentage van het areaal in Montferland waar biodiversiteitswinst te realiseren is wanneer een van deze VER-thema's opgelost wordt en wanneer ze allemaal opgelost worden (Optimaal). 


\subsubsection{Gelderse poort}

De Gelderse poort is een gebied waar zoet water en (half)natuurlijke graslanden worden afgewisseld met moeras en (natte) bossen. In het gebied liggen ook gebieden in de Groene ontwikkelzone

(Figuur 38). De resultaten van de MNP geven aan dat er met name problemen spelen rond verzuring, maar deze resultaten worden niet bevestigd door de deskundigen (Figuur 39). De intactness laat zien dat het gebied nog onvoldoende robuust is (Figuur 38). De deskundigen geven aan dat aansluiting met andere moerassystemen in het rivierengebied nagestreefd moet worden. Daarbij kunnen ook de potenties van beekmondingen gebruikt worden om het areaal moeras in Gelderland te vergroten en robuuster te maken (zie ook 4.5).

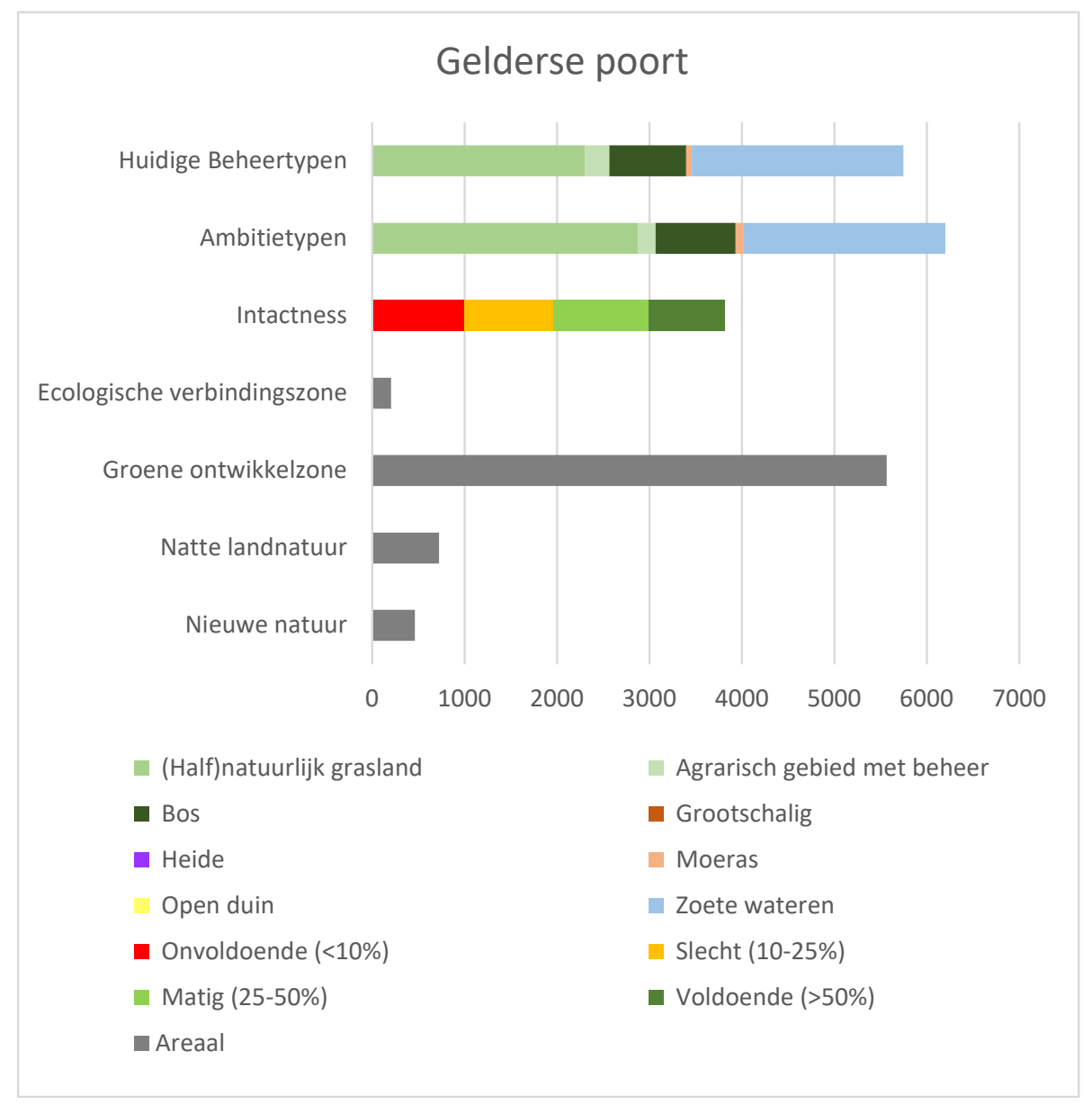

Figuur 38 Kenschets van de Gelderse poort. (Zie 4.7 voor uitleg figuur.) De eenheid van de $x$-as is ha. 


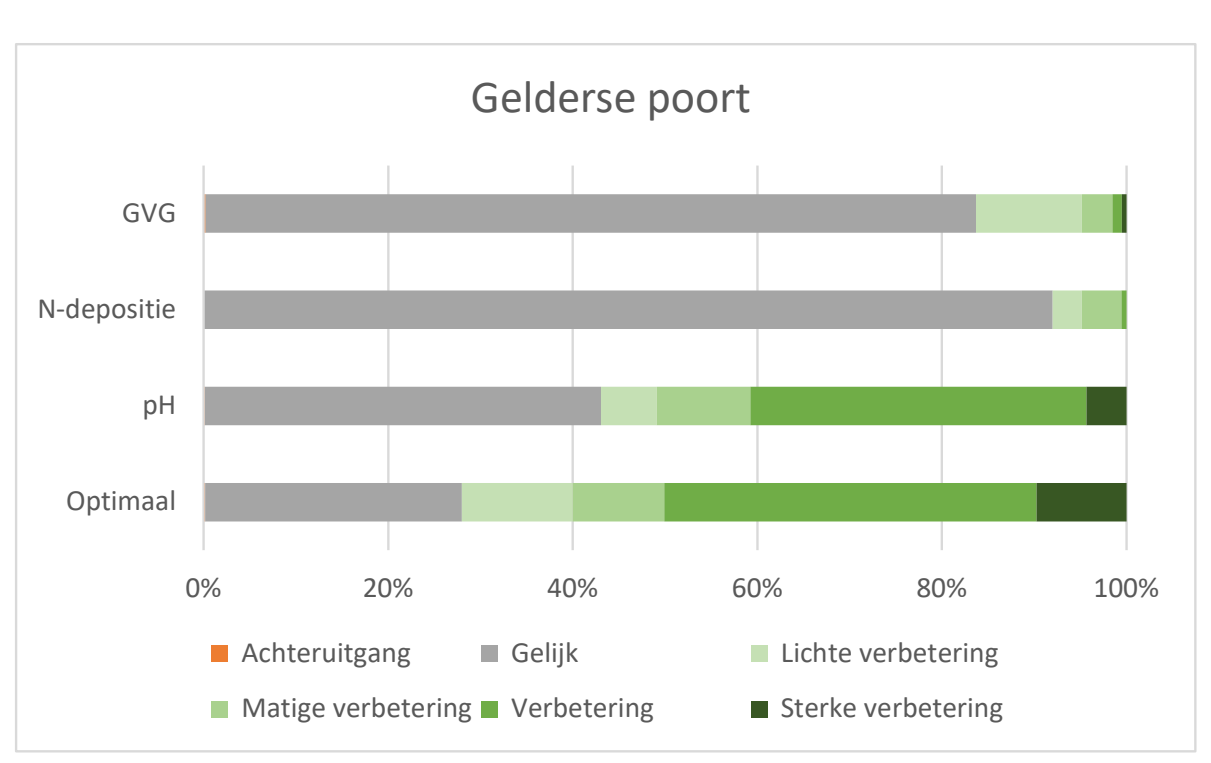

Figuur $39 M N$-resultaten m.b.t. verdroging (GVG), vermesting ( $N$-depositie) en verzuring $(\mathrm{pH})$ voor de Gelderse poort. De staafdiagrammen geven het percentage van de areaal weer waar biodiversiteitswinst te realiseren is wanneer een van deze VER-thema's opgelost worden en wanneer ze allemaal opgelost worden (Optimaal). Door de deskundigen is aangegeven dat de resultaten met betrekking tot verzuring voor de Gelderse poort met voorzichtigheid moeten worden gehanteerd. 


\subsubsection{Overasseltse en Hatertse vennen}

De Overasseltse en Hatertse vennen is een gebied waar aaneengesloten bos wordt afgewisseld met heide, zoet water en (half)natuurlijke graslanden. De intactness geeft aan dat grote delen van het gebied robuust zijn. In het gebied liggen ook gebieden in de Groene ontwikkelzone en Ecologische verbindingszones (Figuur 40). De resultaten van de MNP geven aan dat er met name problemen spelen rond vermesting, maar dat het mee oplossen van verzuring en verdroging in grote delen van het gebied tot toename van biodiversiteit zal leiden (Figuur 41).

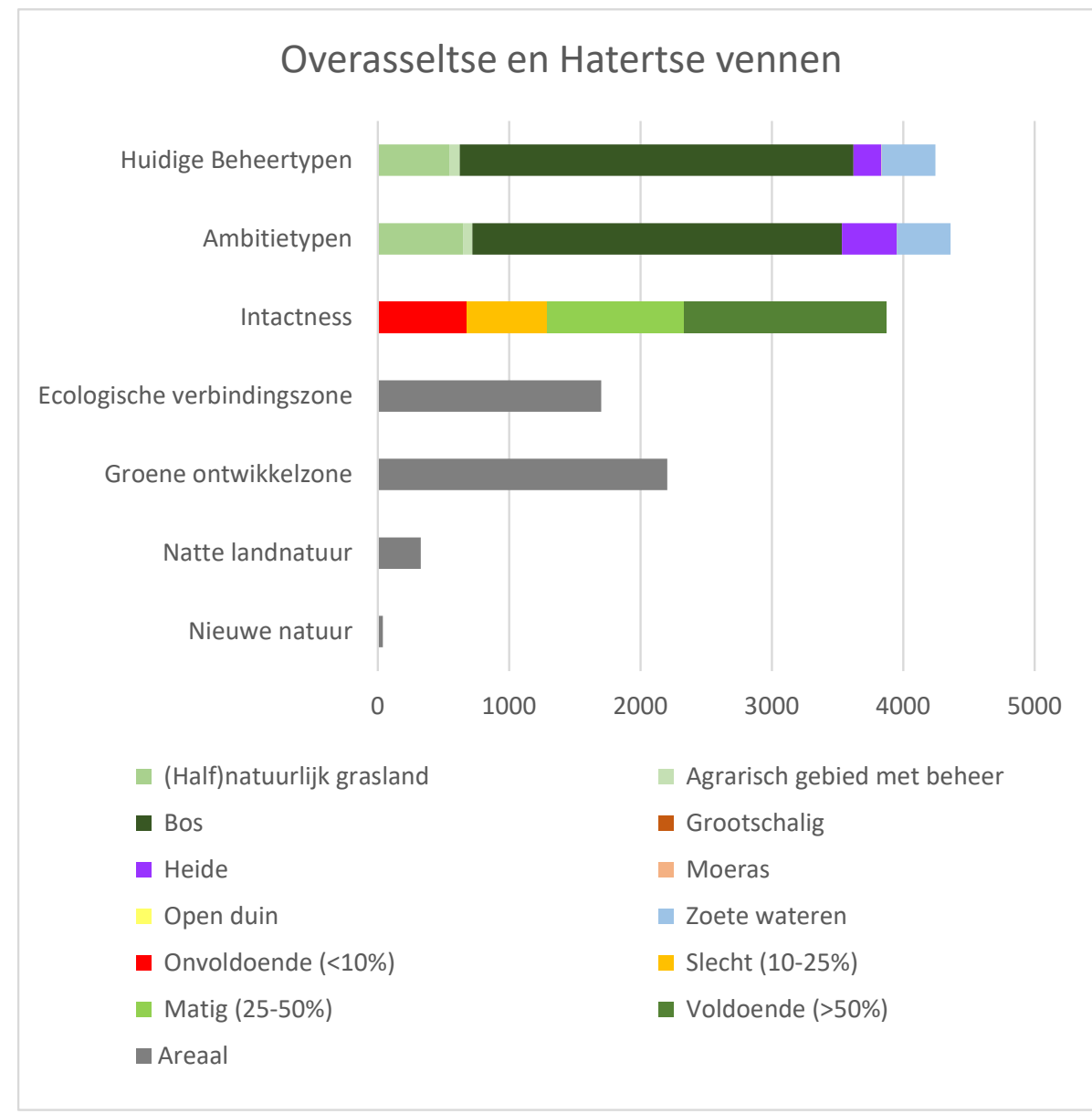

Figuur 40 Kenschets van de Overasseltse en Hatertse vennen. (Zie 4.7 voor uitleg figuur.) De eenheid van de $x$-as is ha. 


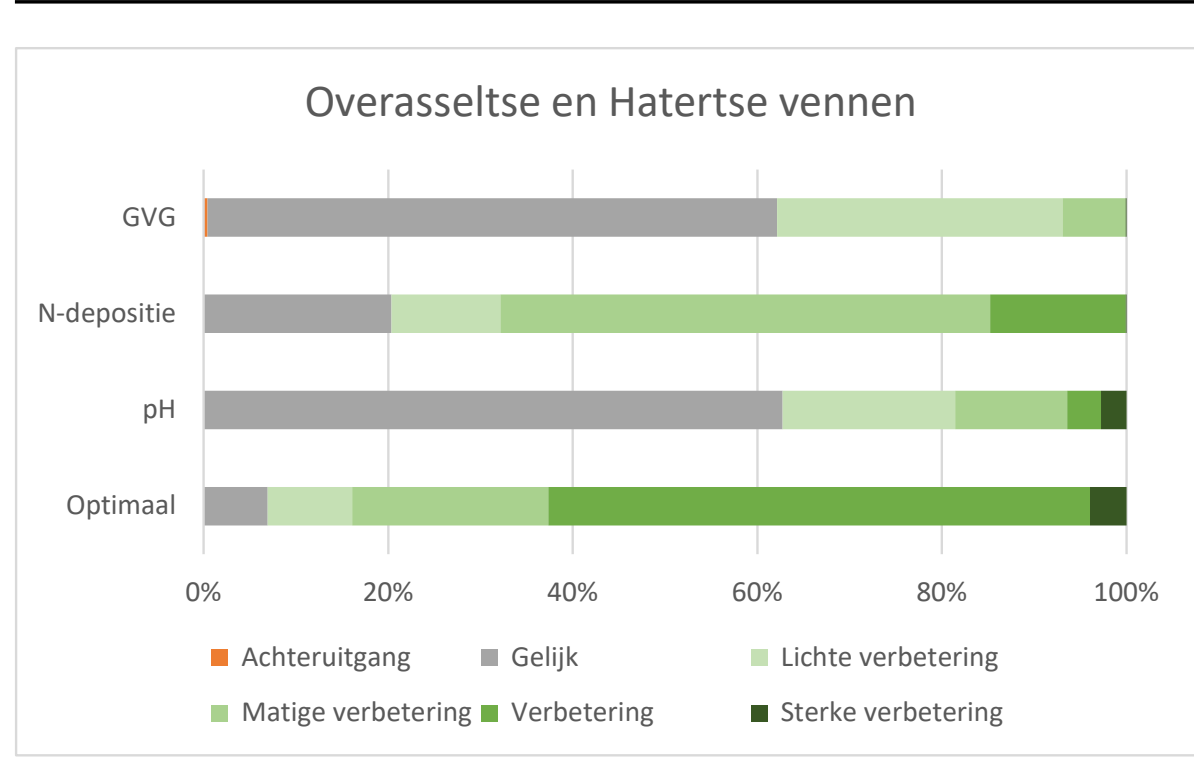

Figuur 41 MNP-resultaten m.b.t. verdroging (GVG), vermesting ( $N$-depositie) en verzuring $(p H)$ voor de Overasseltse en Hatertse vennen. De staafdiagrammen geven het percentage van het areaal weer waar biodiversiteitswinst te realiseren is wanneer een van deze VER-thema's opgelost wordt en wanneer ze allemaal opgelost worden (Optimaal). 


\subsubsection{Bruuk}

De Bruuk is een gebied waar (half)natuurlijke graslanden worden afgewisseld met bos en zoete water. De intactness laat zien dat het gebied nog onvoldoende robuust is. In het gebied liggen ook gebieden in de Groene ontwikkelzone en Natte landnatuur (Figuur 42). De resultaten van de MNP geven aan dat er met name problemen spelen rond verzuring (Figuur 43). De deskundigen geven verder aan dat ook verdroging een belangrijk knelpunt is, met name vanwege de veranderingen in kwelstromen. Deze worden echter niet in het MNP meegenomen, waardoor dit niet in Figuur 42 zichtbaar is.

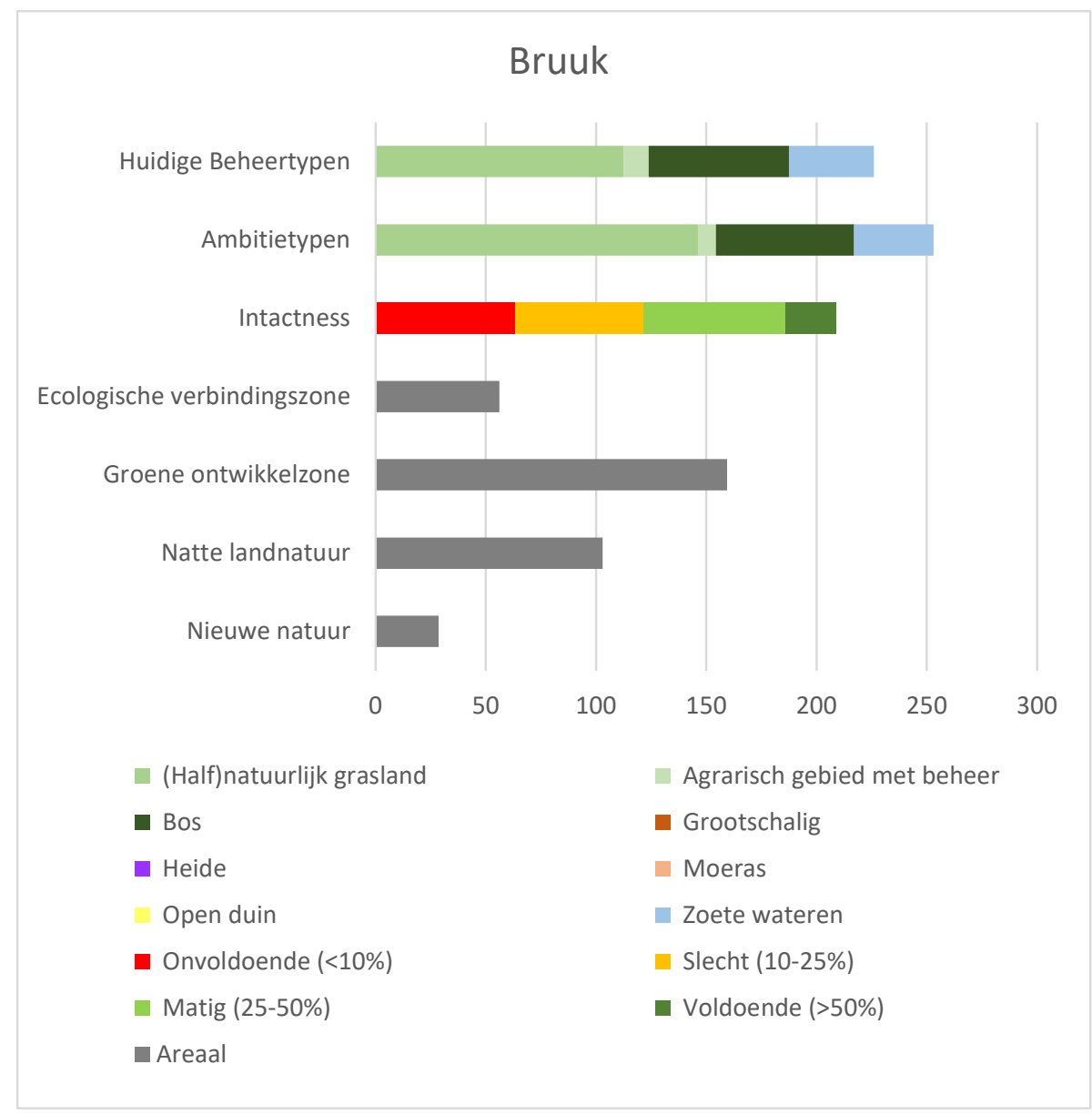

Figuur 42 Kenschets van de Bruuk. (Zie 4.7 voor uitleg figuur.) De eenheid van de $x$-as is ha. 


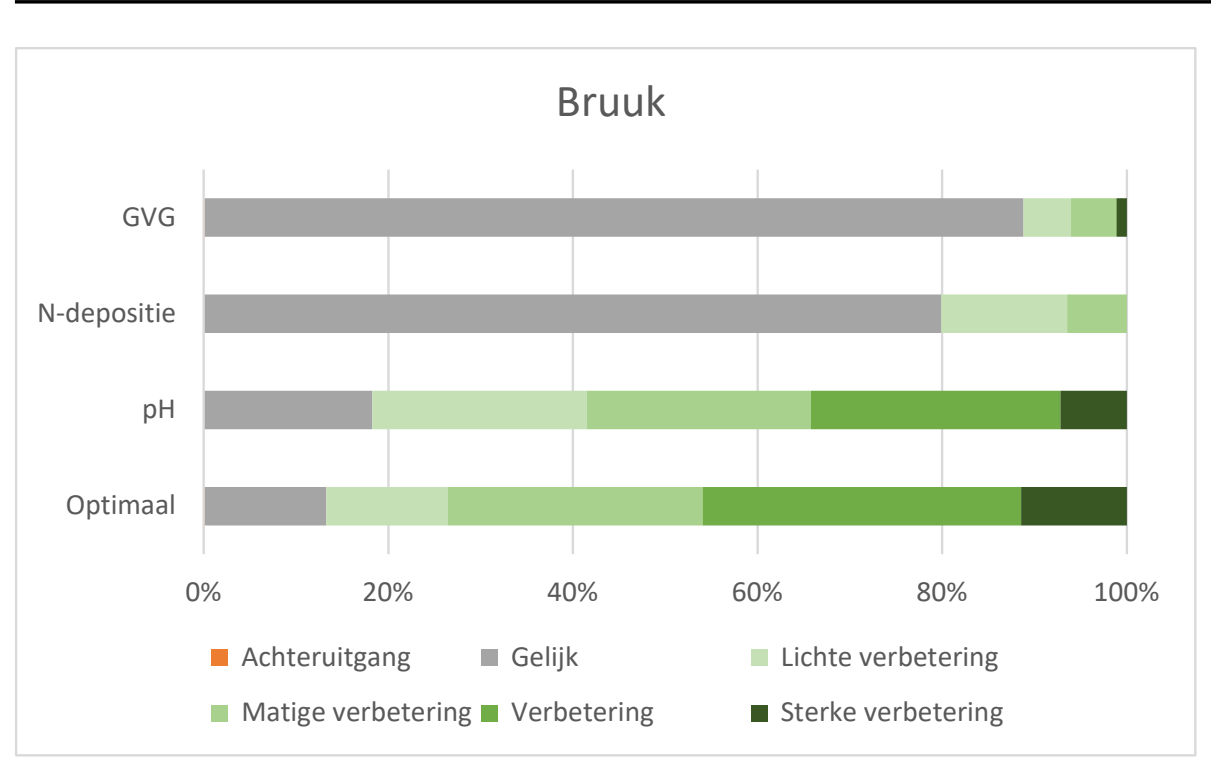

Figuur 43 MNP-resultaten m.b.t. verdroging (GVG), vermesting ( $N$-depositie) en verzuring $(\mathrm{pH})$ voor de Bruuk. De staafdiagrammen geven het percentage van het areaal weer waar biodiversiteitswinst te realiseren is wanneer een van deze VER-thema's opgelost wordt en wanneer ze allemaal opgelost worden (Optimaal). 


\subsubsection{Gorsselse heide}

De Gorsselse heide is een gebied waar met name bossen aanwezig zijn. De intactness laat zien dat grote delen van het gebied robuust zijn. In het gebied liggen ook gebieden in de Groene ontwikkelzone (Figuur 44). De resultaten van de MNP geven aan dat er met name problemen spelen rond verdroging en vermesting (Figuur 45).

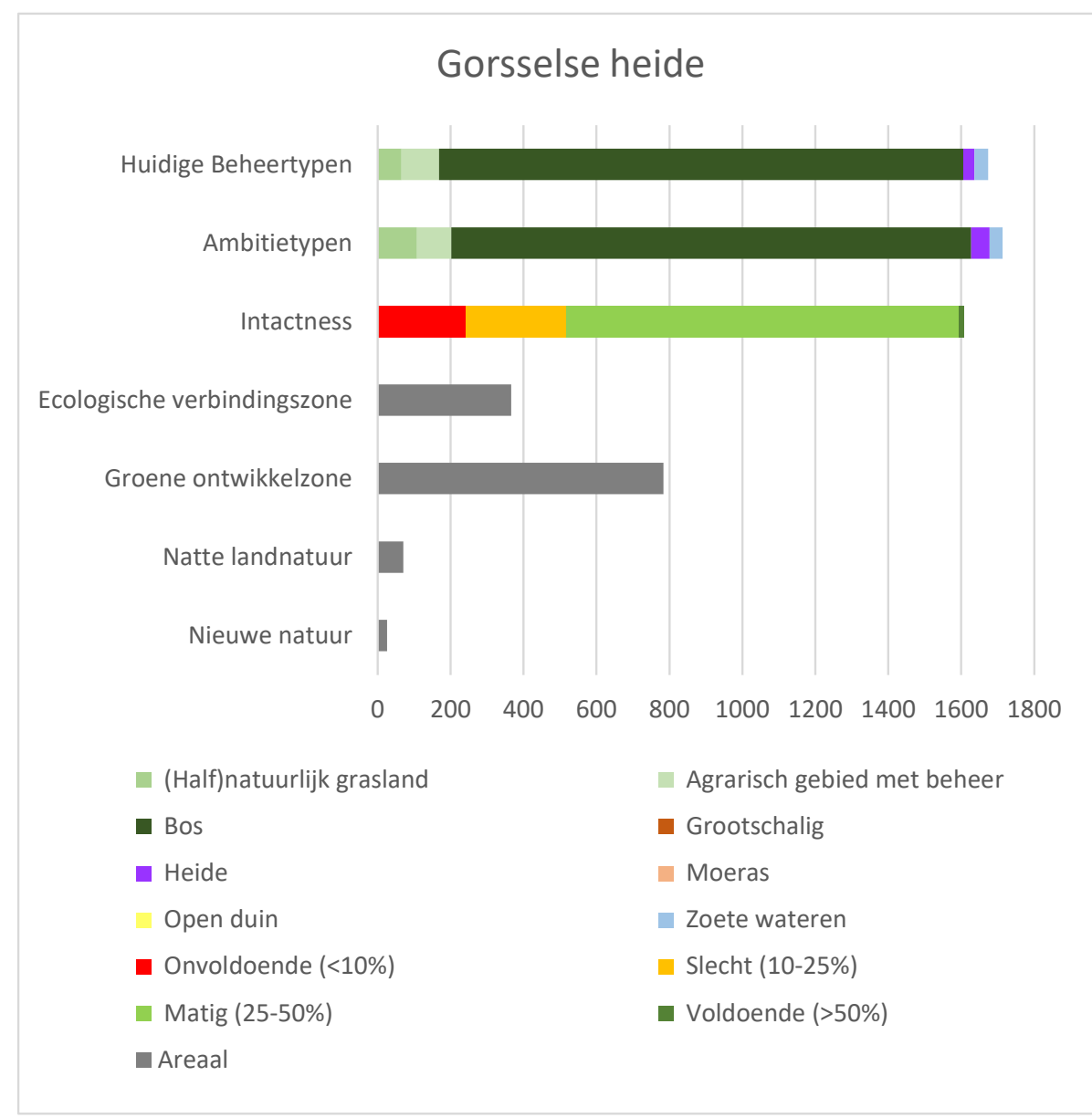

Figuur 44 Kenschets van de Gorsselse heide. (Zie 4.7 voor uitleg figuur.) De eenheid van de $x$-as is ha. 


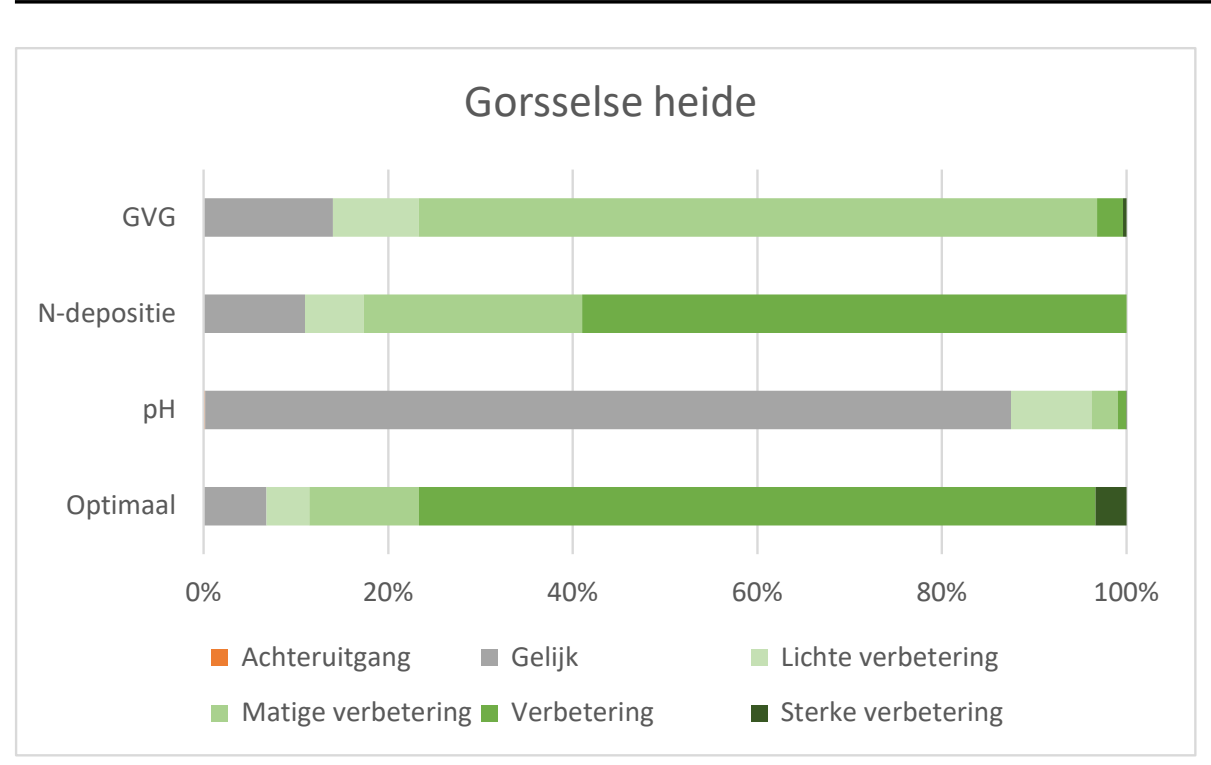

Figuur 45 MNP-resultaten m.b.t. verdroging (GVG), vermesting ( $N$-depositie) en verzuring $(\mathrm{pH})$ voor de Gorsselse heide. De staafdiagrammen geven het percentage van het areaal weer waar biodiversiteitswinst te realiseren is wanneer een van deze VER-thema's opgelost wordt en wanneer ze allemaal opgelost worden (Optimaal). 


\subsubsection{Huis Verwolde e.o.}

Huis Verwolde e.o.is een gebied waar met name bossen aanwezig zijn. De intactness laat zien dat deze erg versnipperd liggen. In het gebied liggen ook gebieden in de Groene ontwikkelzone

(Figuur 46). De resultaten van de MNP geven aan dat er met name problemen spelen rond verdroging en vermesting en dat het gecombineerd oplossen van deze factoren tot sterke verbeteringen leidt

(Figuur 47).

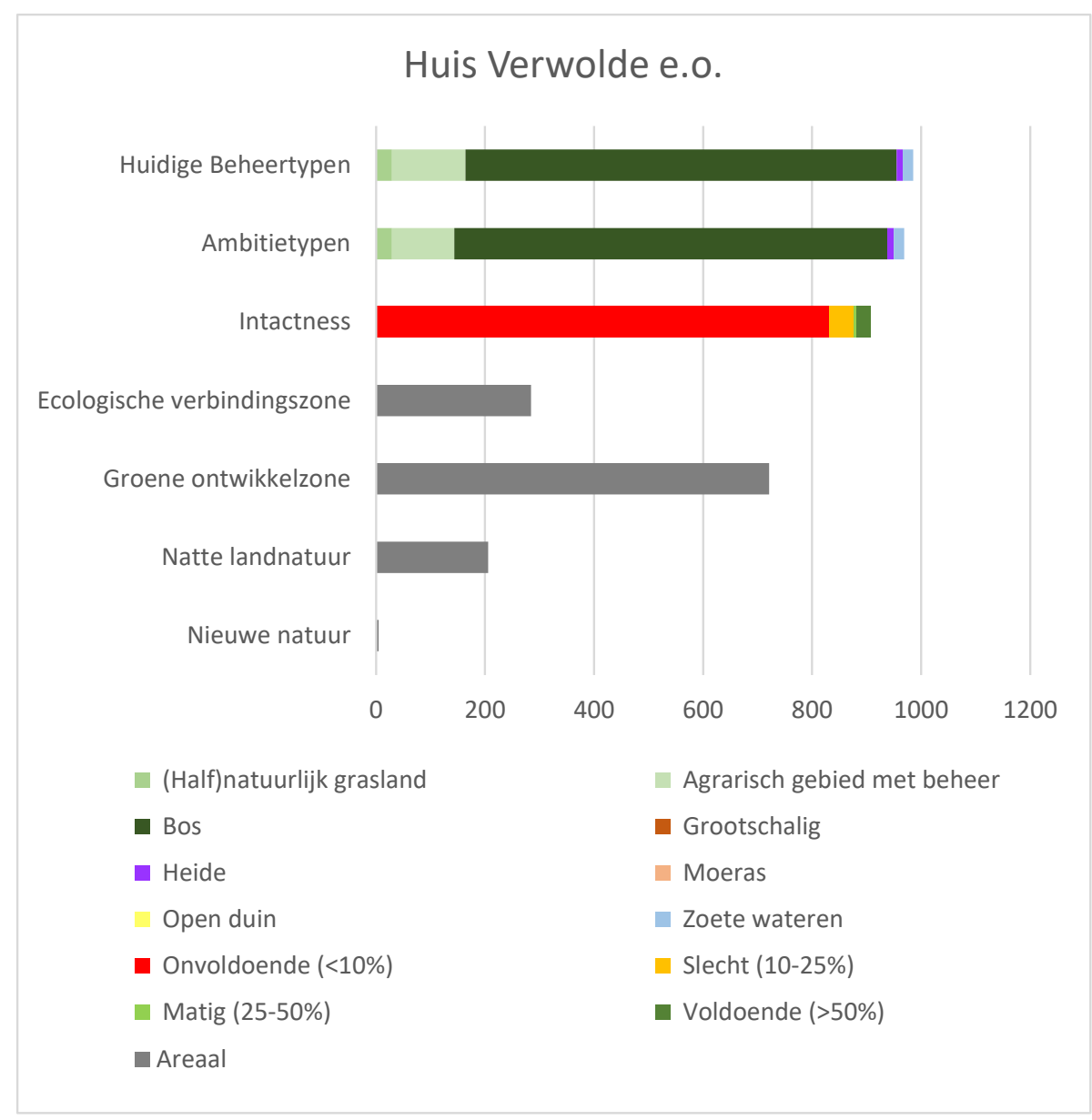

Figuur 46 Kenschets van Huis Verwolde e.o. (Zie 4.7 voor uitleg figuur.) De eenheid van de $x$-as is ha. 


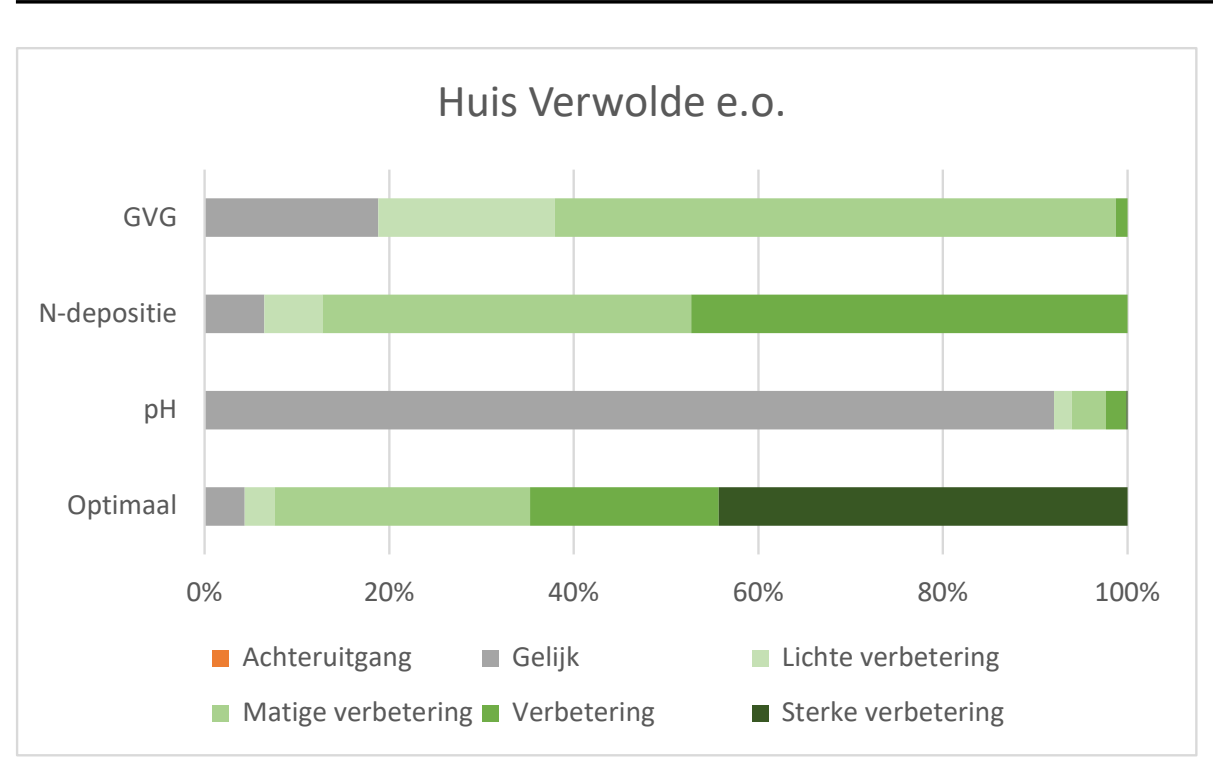

Figuur 47 MNP-resultaten m.b.t. verdroging (GVG), vermesting ( $N$-depositie) en verzuring $(\mathrm{pH})$ voor Huis Verwolde e.o. De staafdiagrammen geven het percentage van het areaal weer waar biodiversiteitswinst te realiseren is wanneer een van deze VER-thema's opgelost wordt en wanneer ze allemaal opgelost worden (Optimaal). 


\subsubsection{Lankheet e.o.}

Lankheet e.o. is een gebied waar met name bossen aanwezig zijn. De intactness laat zien dat grote delen van het gebied robuust zijn. In het gebied liggen ook gebieden in de Ecologische verbindingszones, Groene ontwikkelzone en Natte landnatuur (Figuur 48). De resultaten van de MNP geven aan dat er met name problemen spelen rond verdroging en vermesting en dat het gecombineerd oplossen van deze factoren tot sterke verbeteringen leidt (Figuur 49).

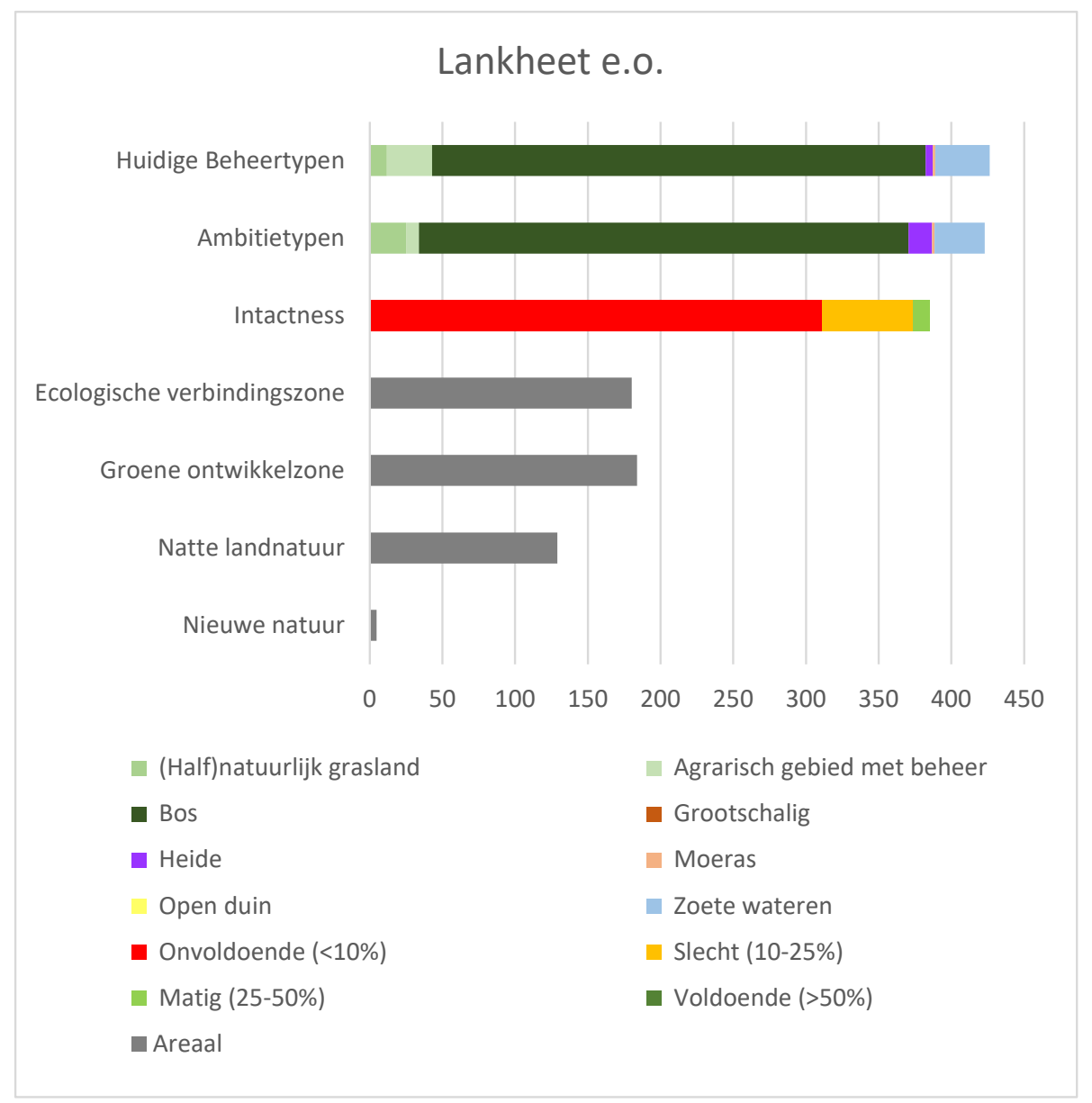

Figuur 48 Kenschets van Lankheet e.o. (Zie 4.7 voor uitleg figuur.) De eenheid van de $x$-as is ha. 


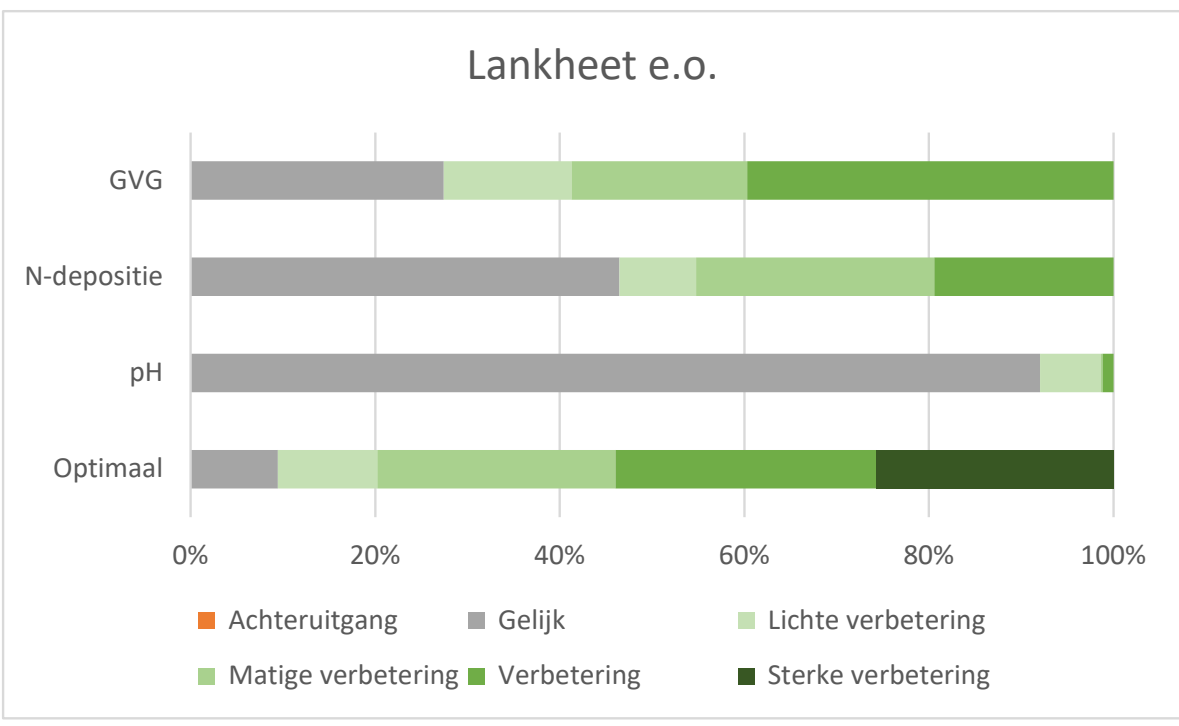

Figuur 49 MNP-resultaten m.b.t. verdroging (GVG), vermesting ( $N$-depositie) en verzuring $(p H)$ voor Lankheet e.o. De staafdiagrammen geven het percentage van het areaal weer waar biodiversiteitswinst te realiseren is wanneer een van deze VER-thema's opgelost wordt en wanneer ze allemaal opgelost worden (Optimaal).

\subsection{Ecologische prioritering gebieden/regio's}

De expertmeetings hebben geresulteerd in een selectie van meerdere gebieden/regio's waar additionele maatregelen zullen leiden tot een biodiversiteitswinst. Om een goede prioritering te kunnen maken, is additionele informatie nodig waar kansen liggen vanuit regionale ontwikkeling, informatie over actuele verspreiding van soorten en informatie over aquatische natuur. Aangezien de deskundigen aangeven dat de grootste verdere biodiversiteitswinst waarschijnlijk gerealiseerd kan worden in het landelijke gebied is nagegaan in welke van de geselecteerde gebieden/regio's kansen liggen buiten de huidige NNN. Daarbij is op basis van de studie van Bouwma et al. (2009) nagegaan waar in Gelderland actuele natuurwaarden aanwezig zijn van de Vogel- en Habitatrichtlijn buiten het NNN. Deze informatie is gecombineerd met de resultaten uit de expertmeetings en de resultaten van de MNP, waardoor een top 10 verkregen is (Tabel 2) van gebieden waar kansen liggen voor het verbeteren van de biodiversiteit in het landelijk gebied. In deze gebieden/regio's lijken er met name kansen te liggen door landbouw en natuur in samenhang te realiseren, natuurinclusieve landbouw.

De prioriteit laat zien dat verwacht wordt dat de meeste biodiversiteitswinst gerealiseerd kan worden in Winterswijk e.o., de Veluwe en de Achterhoek. Daarnaast wordt ook een hoge biodiversiteitswinst verwacht wanneer maatregelen genomen worden in de Landgoederenzone tussen Veluwe en IJssel, Beken en sprengen IJsselvallei en het Grote veld e.o.. Met betrekking tot het Groene Valleilint, Binnenveld, Rivierengebied en de Gelderse Poort liggen er ook kansen. In het Rivierengebied geven de deskundigen aan dat er specifieke kansen liggen bij mondingen van beken. Hier kunnen hogere ambities voor bijvoorbeeld moerastypen worden nagestreefd.

Deze top 10 moet als indicatie gezien worden. Enkele kanttekeningen zijn:

- alle ecosystemen en soorten worden even zwaar meegewogen en er is niet beoordeeld in hoeverre ze momenteel onder druk staan;

- er is geen rekening gehouden met de realiseerbaarheid van de biodiversiteitswinst. Zo geven de deskundigen aan dat voor een gezond ecosysteem in bijvoorbeeld het Binnenveld en de Achterhoek maatregelen op het schaalniveau van het landschap nodig zijn;

- er is geen rekening gehouden met de mogelijk effecten van klimaatverandering, waardoor bepaalde ecosystemen en soorten eerder onder druk komen te staan dan andere;

- er is geen rekening gehouden met knelpunten van aquatische natuur; 
- de actuele VHR-waarden zijn gebaseerd op Bouwma et al. (2009). Mogelijk dat recentere gegevens tot een andere prioritering zouden leiden;

- bij de gekozen methode van prioritering zullen grotere gebieden/regio's eerder naar voren komen als prioritaire gebieden.

Tabel 2 Indicatieve top 10 gebieden/regio's op basis van resultaten expertmeetings, resultaten MNP en actuele waarden buiten NNN (Bouwma et al. 2009). Bij de actuele waarden wordt aangegeven wat de soortgroepen zijn die het meeste buiten de NNN voorkomen in deze gebieden/regio's. Voor de gebieden/regio's Winterswijk e.o. en Achterhoek betreft dit een mix over alle soortgroepen heen.

\begin{tabular}{|c|c|c|c|}
\hline Top 10 & expertmeetings & MNP & $\begin{array}{l}\text { actuele waarden buiten } \\
\text { NNN } \\
\text { (Bouwma et al. 2009) }\end{array}$ \\
\hline 14 Achterhoek & landschapsherstel & $\begin{array}{l}\text { geïsoleerde en versnipperde } \\
\text { natuur }\end{array}$ & $\begin{array}{l}\text { mix: aquatisch, grasland, } \\
\text { bos }\end{array}$ \\
\hline $\begin{array}{l}10 \text { Landgoederenzone } \\
\text { Veluwe-IJssel/Zutphen }\end{array}$ & & $\begin{array}{l}\text { onvoldoende robuust; } \\
\text { gecombineerd effect } \\
\text { drukfactoren }\end{array}$ & vleermuizen, amfibieën \\
\hline 11 Grote veld e.o. & ontsnippering watersysteem & vermesting (en verdroging) & vleermuizen \\
\hline 4 Groene Valleilint & $\begin{array}{l}\text { creëren lokale kernen, verbinding } \\
\text { met natuur Utrecht }\end{array}$ & $\begin{array}{l}\text { onvoldoende robuust; } \\
\text { verdroging en vermesting }\end{array}$ & vleermuizen, amfibieën \\
\hline 5 Binnenveld & $\begin{array}{l}\text { fundamentele maatregelen nodig } \\
\text { doordat gebied ingeklemd ligt }\end{array}$ & $\begin{array}{l}\text { onvoldoende robuust, } \\
\text { geïsoleerd; verdroging }\end{array}$ & $\begin{array}{l}\text { broedvogels natte } \\
\text { systemen }\end{array}$ \\
\hline 7 Rivierengebied & kwel; kansen mondingen beken & onvoldoende robuust & $\begin{array}{l}\text { moerasvogels, vissen, } \\
\text { amfibieën }\end{array}$ \\
\hline
\end{tabular}




\section{Literatuur}

Bell, S., L. Tyrväinen, T. Sievänen, U. Pröbstl, and M. Simpson, 2007. Outdoor recreation and nature tourism: A European perspective. Living Reviews in Landscape Research 1:1-46.

Bouwma, I.M., Janssen, J.A.M., Hennekens, S.M., Kuipers, H., Paulissen, M.P.C.P., Niemeijer, C.M., de Vries, M.W., Pouwels, R., Sanders, M.E. and Epe, M.J., 2009. Realisatie landelijke doelen Vogelen Habitatrichtlijn: een onderzoek naar de noodzaak voor aanvullende beleidsmaatregelen ter realisatie van de landelijke doelen van de Vogel-en Habitatrichtlijn (No. 1835). Alterra.

CBD, 2014. Strategic Plan for Biodiversity 2011-2020, including Aichi Biodiversity Targets Retrieved 18/04/2014, from http://www.cbd.int/sp/

CBD, 2010. Report of the tenth meeting of the conference of the parties to the convention on biological diversity, In COP10. p. 353. UNEP, Nagoya, Japan.

Erisman, J.W., Eekeren, N. van, Doorn, A. van, Geertsema, W., Polman, N., 2017. Wageningen: Wageningen Environmental Research, Wageningen Environmental Research rapport 2821.

Lawton, J.H., Brotherton, P.N.M., Brown, V.K., Elphick, C., Fitter, A.H., Forshaw, J., Haddow, R.W., Hilborne, S., Leafe, R.N., Mace, G.M. and Southgate, M.P., 2010. Making Space for Nature: a review of England's wildlife sites and ecological network. Report to DEFRA.

Bascompte, J. and Jordano, P., 2007. Plant-animal mutualistic networks: the architecture of biodiversity. Annu. Rev. Ecol. Evol. Syst., 38, pp.567-593.

Ferrier, S., \& Drielsma, M., 2010. Synthesis of pattern and process in biodiversity conservation assessment: a flexible whole-landscape modelling framework. Diversity and Distributions, 16(3), 386-402.

Foppen, R., J. Graveland, M. de Jong en A. Beintema, 1998. Naar levensvatbare populaties moerasvogels; achtergrond document voor 'Beschermingsplan Moerasvogels' van Vogelbescherming Nederland. IBN-rapport 393, IBN-DLO, Wageningen.

Grinnell, J., 1917. Field tests of theories concerning distributional control. The American Naturalist, 51(602), 115-128.

Hirzel, A.H. en Le Lay, G., 2008. Habitat suitability modelling and niche theory. Journal of Applied Ecology, 45(5), pp.1372-1381.

Hodgson, J.A., A. Moilanen, B.A. Wintle, and C.D. Thomas, 2011. Habitat area, quality and connectivity: striking the balance for efficient conservation. Journal of Applied Ecology 48:148-152.

Jongman, R.H.G., 2002. Homogenisation and fragmentation of the European landscape: ecological consequences and solutions. Landscape and urban planning, 58(2), pp.211-221.

Mace, G.M., 2014. Whose conservation? Science 345:1558-1560.

Maller, C., M. Townsend, A. Pryor, P. Brown, and L. St Leger, 2006. Healthy nature healthy people: 'contact with nature' as an upstream health promotion intervention for populations. Health promotion international 21:45-54.

Montoya, J.M., Pimm, S.L. and Solé, R.V., 2006. Ecological networks and their fragility. Nature, 442(7100), pp.259-264.

Opdam, P., J. Verboom and R. Pouwels, 2003. Landscape cohesion: an index for the conservation potential of landscapes for biodiversity. Landscape Ecology 18:113-126.

Ovaskainen, O., 2013. How to develop the nature conservation strategies for The Netherlands. De Levende Natuur, 114(2), 59-62.

PBL, 2010. Adaptatiestrategie voor een klimaatbestendige natuur. Beleidsstudie Planbureau voor de Leefomgeving, Vonk, M.; C.C. Vos, \& D.C.J. van der Hoek (Ed) nr. 500078002, Bilthoven.

$\mathrm{PBL}, 2012$. Effecten van klimaatverandering in Nederland: 2012. Beleidsstudie. Planbureau voor de Leefomgeving (PBL). Rapportnummer 500193003, Den Haag.

PBL en WUR, 2017a. Lerende evaluatie van het Natuurpact. Naar nieuwe verbindingen tussen natuur, beleid en samenleving, Den Haag: PBL.

PBL \& WUR, 2017b. European nature in the plural: finding common ground for a next policy agenda (No. 1615). PBL Netherlands Environmental Assessment Agency.

Pimm, S.L., 1982. Food webs. In Food webs (pp. 1-11). Springer Netherlands. 
Pouwels, R., G.W.W. Wamelink, M.H.C. van Adrichem, R. Jochem, R.M.A. Wegman en B. de Knegt. (in prep). MNP v4.0 Status A; toepassing voor Evaluatie Natuurpact. Wettelijke Onderzoekstaken Natuur \& Milieu, WOt-technical report.

Pouwels, R., Sierdsema, H., Foppen, R.P., Henkens, R.J., Opdam, P.F. and van Eupen, M., 2017. Harmonizing outdoor recreation and bird conservation targets in protected areas: Applying available monitoring data to facilitate collaborative management at the regional scale. Journal of Environmental Management, 198, pp.248-255.

Pouwels, R., M. van Eupen, M.H.C. van Adrichem, B. de Knegt \& J.G.M. van der Greft, $2016 a$. MetaNatuurplanner v2.0; Status A. WOt-technical report 64. Wettelijke Onderzoekstaken Natuur \& Milieu.

Pouwels, R., W.G.M. van der Bilt, A. van Hinsberg, B. de Knegt, R. Reijnen, J. Verboom, en L.M. Jones-Walters, 2016b. Assessing biodiversity change in scenario studies: introducing a decision support tool for analysing the impact of nature policy. WOt paper 39. WOT Natuur \& Milieu, Wageningen UR, Wageningen.

Skelhorn, C., Lindley, S., \& Levermore, G., 2014. The impact of vegetation types on air and surface temperatures in a temperate city: A fine scale assessment in Manchester, UK. Landscape and Urban Planning, 121, 129-140.

Star, S.L., J.R. Griesemer, 1989. Institutional ecology, 'translations' and boundary objects: amateurs and professionals in Berkeley's Museum of Vertebrate Zoology, 1907 - 39. Social Studies of Science 19:387-420.

US Fish and Wildlife Service, 1981. Standards for the Development of Habitat Suitability Index Models for Use with the Habitat Evaluation Procedures. US Fish and Wildlife Service.

Van den Burg, A., 2017. Rammelende eieren en brekebenen bij de koolmees : verzuring terug bij af? Vakblad natuur bos landschap / Stichting Vakblad Natuur Bos Landschap. 136:3-7.

Van der Hoek, D-J., M. Smit, S. van Broekhoven, H. Bredenoord, P. Giesen, A. van Hinsberg, R. Folkert, R. Pouwels, B. de Knegt, F. van Gaalen, S. van Tol, S. Mylius, A. de Blaeij, V. Linderhof, 2017. Potentiële bijdrage van provinciaal natuurbeleid aan Europese biodiversiteitsdoelen. Achtergrondrapport lerende evaluatie van het Natuurpact, Den Haag: PBL.

Van Doorn, A., Westerink, J., Nieuwenhuizen, W., Melman, D., Schrijver, R., Breman, B., 2017. Verder vergroenen, verder verbreden : naar een effectieve bijdrage van het Europees landbouwbeleid en beleid voor agrarisch natuurbeheer aan groene opgaven. Wageningen: Wageningen Environmental Research, (Wageningen Environmental Research rapport 2822),

Van Hattum, T., Kwakernaak, C., Tol-Leenders, T.V., Roelsma, J., Broekmeyer, M.E.A., Schmidt, A.M., Hartgers, E.M. and Nysingh, S.L., 2014. Water en natuur: een mooi koppel. Onderzoek naar de succesfactoren, belemmeringen en kansen voor het meekoppelen van water- en natuuropgaven. Alterra-rapport 2533.

Van Kleunen, A., van Dobben, H.F. \& Schmidt, A.M., 2007. Habitataspecten en drukfactoren voor soorten. Rapport in het kader van het WOT Programma Informatievoorziening Natuur i.o. (WOT IN). Alterra, Alterra-rapport 1584, WOT IN serie nr. 6.

Verboom, J., Foppen, R., Chardon, P., Opdam, P., \& Luttikhuizen, P., 2001. Introducing the key patch approach for habitat networks with persistent populations: an example for marshland birds. Biological Conservation, 100(1), 89-101.

Verweij, P., S. Janssen, L. Braat, M. van Eupen, M. Pérez Soba, M. Winograd, W. de Winter and A. Cormont, 2016. QUICKScan as a quick and participatory methodology for problem identification and scoping in policy processes, Environmental Science \& Policy, 66, pp.47-61,

Vos, C.C., Grashof-Bokdam, C.J. and Opdam, P.F.M., 2014. Biodiversity and ecosystem services: does species diversity enhance effectiveness and reliability? (No. 25). Wettelijke Onderzoekstaken Natuur \& Milieu.

Wamelink, G.W.W., De Knegt, B., Pouwels, R., Schuiling, C., Wegman, R.M.A., Schmidt, A.M., Van Dobben, H.F. and Sanders, M.E., 2013. Considerable environmental bottlenecks for species listed in the Habitats and Birds Directives in the Netherlands. Biological conservation, 165, pp.43-53.

Williams, B.K., R.C. Szaro, and C.D. Shapiro, 2007. Adaptive Management: The U.S. Department of the Interior Technical Guide. Adaptive Management Working Group, The U.S. Department of the Interior, Washington, DC. 


\section{Overige literatuur bijlagen}

Carignan, V., \& Villard, M.A., 2002. Selecting indicator species to monitor ecological integrity: A review. Environmental Monitoring and Assessment, 78(1), 45-61.

Eglington, S.M., D.G. Noble and R.J. Fuller, 2012. A meta-analysis of spatial relationships in species richness across taxa: Birds as indicators of wider biodiversity in temperate regions. Journal for Nature Conservation 20:301-309.

RIVM, 2015. Grootschalige concentratie- en depositiekaarten Nederland. Rapportage 2015. 30 RIVM: Bilthoven. RIVM Rapport 2015-0119.

Sierdsema, H., van Diermen, J., Aarts, B.G.W., Bremer, L. and van Kleunen, A., 2008. Factsheets van broedvogels in de Natura 2000-gebieden van Gelderland. SOVON Vogelonderzoek Nederland.

Sierdsema, H., R. Wolf, A. van Kleunen, Loes van den Bremer, Laurens Sparrius, John Smit, Adriaan Gmelig Meyling, Tim Termaat, Jan Kranenbarg, Hans Hollander \& Ronald Zollinger, 2015. Leefgebiedkaarten van de Gelderse Natura2000-gebieden. Sovon-rapport 2015/67. Sovon Vogelonderzoek Nederland, Nijmegen.

Terell, J.W., McMahon, T.E., Inskip, P.D., Raleigh, R.F. and Williamson, K.L., 1982. Habitat suitability index model. Guidelines for riverine and lacustrine applications of fish HSImodels with the Habitat Evaluation Procedure. Washington DC: US Fish and Wildlife Service.

Van Beek, J.G., R.F. van Rosmalen, B.F. van Tooren \& P.C. van der Molen, 2014. Werkwijze Monitoring en Beoordeling Natuurnetwerk en Natura 2000/PAS, Utrecht: BIJ12.

Van Delft, S.P.J., T. Hoogland, W.M.L. Meijninger en G.J. Roerink, 2017. Verdrogingsinformatie voor de Nederlandse natuur; Een vergelijking tussen de actuele en gewenste grondwatersituatie. Rapport 2792. Wageningen, Wageningen Environmental Research.

Van der Hoek, D.C.J., P. Giesen, R. Pouwels, H. Meeuwsen, G.W.W. Wamelink, B. de Knegt en A. van Hinsberg (in prep.). Toepassing MNP voor Evaluatie Natuurpact. Beschrijving realisatie van invoerbestanden voor huidige en toekomstige situatie. WOt-werkdocument, Wettelijke Onderzoekstaken Natuur \& Milieu, Wageningen.

Van Turnhout, C., E. Brouwer, M. Nijssen, S. Stuijfzand, J. Vogels, H. Siepel \& H. Esselink, 2008. Herstelmaatregelen in heideterreinen; invloed op de fauna - Samenvatting OBN onderzoek en richtlijnen met betrekking tot de fauna, Rapport DK nr. 2008/042-O, Ede: Ministerie van Landbouw, Natuur en Voedselkwaliteit.

Verbrugge, L.N.H., L. de Hoop, R.S.E.W. Leuven, R. Aukema, R. Beringen, R.C.M. Creemers, G.A. van Duinen, H. Hollander, M. Scherpenisse, F. Spikmans, C.A.M. van Turnhout, S. Wijnhoven \& E. de Hullu, 2015. Expertpanelbeoordeling van (potentiële) risico's en managementopties van invasieve exoten in Nederland: Inhoudelijke input voor het Nederlandse standpunt over de plaatsing van soorten op EU-verordening 1143/2014. Verslagen Milieukunde nr. 486. Radboud Universiteit Nijmegen, Nijmegen.

Wamelink, G.W.W., Wegman, R.M.A., Knotters, M., 2015. MetaNatuurplanner. Tussenrapportage WOT-04-011-036.45. Wageningen : Wettelijke Onderzoekstaken Natuur en Milieu (WOt-interne notitie 96).

Wolters, V., Bengtsson, J., \& Zaitsev, A.S., 2006. Relationship among the species richness of different taxa. Ecology, 87(8), 1886-1895, 


\section{Bijlage 1 Domein en afbakeningen MNP}

De MNP beoordeelt of de condities in het landschap op voldoende locaties geschikt zijn voor een soort om zich in het landschap te kunnen handhaven. Voordeel van het model is dat effecten worden gekwantificeerd en gevolgen van geheel verschillende type maatregelen bij elkaar worden opgeteld (integrale analyses). Nadeel is dat dit alleen kan door de werkelijkheid sterk te vereenvoudigen. De belangrijkste kanttekeningen bij het gebruik zijn:

\section{B1.1 Afbakeningen kwaliteit leefgebied}

De mate waarin het leefgebied geschikt is, wordt bepaald door eenvoudige responsiecurves (paragraaf 2.6 in Pouwels et al. 2016a en Bijlage 3) te gebruiken. Voor de bepaling van de parameterwaarden wordt zo veel mogelijk gebruik gemaakt van empirisch onderzoek met betrekking tot bijvoorbeeld optimale grondwaterstanden en kritische waarden voor atmosferische depositie (paragraaf 3.3-3.5). Voor sommige soorten wordt bij de bepaling van deze waarden gebruikgemaakt van relaties uit meer geavanceerde procesmodellen, zoals LARCH en de Natuurplanner en voor enkele soorten worden ze bij geschat op basis van aanverwante soorten (3.1.5 en 3.6).

Sommige factoren die meer lokaal bepalend zijn voor de aanwezigheid van soorten, zoals jacht (of andere beïnvloeding/verstoring), barrières (wegen, hekken, etc.), worden in het model niet beschouwd. Ook wordt de impact van invasieve soorten buiten beschouwing gelaten. Deze impact betreft echter met name soorten in aquatische milieus (Verbrugge et al. 2015). Het niet meenemen van klimaatverandering wordt als grootste hiaat met betrekking tot evaluaties van toekomstig beleid gezien. De invloed van klimaatverandering is met name van belang wanneer beoordelingen van toekomstscenario's worden gedaan die niet betrekking hebben op de nabije toekomst, maar op bijvoorbeeld 2050 of 2100.

Het model gaat ervan uit dat de fysieke maatregelen qua beheer optimaal worden uitgevoerd. Er wordt als het ware aangenomen dat bijvoorbeeld plaggen of maaien gebeurt in het, voor alle soorten, goede seizoen, met de juiste frequentie en ruimtelijke schaal. In de praktijk blijkt het echter lastig om fysieke ingrepen ecologisch volledig goed uit te voeren (Van Turnhout et al. 2008). Als bijvoorbeeld het natuurbeheer op te grote schaal of te frequent wordt uitgevoerd, kan er zelfs schade aan de natuur ontstaan doordat soorten verdwijnen.

Voor het bepalen van de geschiktheid van het leefgebied (stap 1) wordt gebruikgemaakt van een eenvoudige HSI-modelstructuur (Habitat Suitability Index). De index ligt tussen 0 en 1 en geeft de ratio aan van de kwaliteit van het onderzochte gebied ten opzichte van een 'perfect' gebied. Ook al hebben HSI-modellen hun beperkingen (Bender et al. 1996) en kunnen ze een grote onzekerheid hebben, ze zijn algemeen geaccepteerd om op een eenvoudige en inzichtelijke wijze de geschiktheid van het leefgebied in beeld te brengen (Terell, 1982; Duel et al. 1996; Sierdsema et al. 2015). In de MNP werken de verschillende drukfactoren versterkend op elkaar en worden de indexen met elkaar vermenigvuldigd. Deze opzet is ook gebruikt voor meer recentere HSI-modellen voor vogels op de Veluwe (Sierdsema et al. 2008), terwijl in een andere studie - tevens voor andere soorten in Gelderland - indexwaarden gesommeerd worden (Sierdsema et al. 2015). Doordat er slechts drie drukfactoren zijn, zal dit alleen tot ongeschikt leefgebied leiden als minimaal één van de factoren leidt tot een ongeschikte situatie. Wanneer alle factoren suboptimaal verondersteld worden, blijft de index boven $0.1(0.5 \times 0.5 \times 0.5=0.125)$ en blijft het leefgebied meedoen bij verdere analyses. Het is voor de ontwikkeling van de MNP van belang te realiseren dat bij het toevoegen van een extra drukfactor, de gekozen methode kan leiden tot ongeschikt leefgebied als alle factoren suboptimaal verondersteld worden. Mogelijk dat het kiezen van het minimum van alle factoren dan een beter beeld geeft van het leefgebied van een soort. Bij het toevoegen van $\mathrm{pH}$ als factor is dit nog niet het geval. Door de US Fish 
and Wildlife Service (1981) wordt vaak het geometrische gemiddelde genomen. Deze functie heeft echter ook zijn eigen nadelen.

\section{B1.1.1 Afbakeningen duurzaam voorkomen soorten}

Het model brengt geen daadwerkelijk (duurzaam) voorkomen van soorten in kaart. Het model analyseert of de condities geschikt zijn voor het duurzaam voortbestaan van soorten. Het model bekijkt per locatie de benodigde condities van de daar voorkomende soorten en vergelijkt dit met de berekende condities. De condities van een leefgebied van een soort worden bepaald door de omvang van het leefgebied (ruimtelijke samenhang) en de geschiktheid ervan. Het geeft op deze wijze de potentie voor een gebied als leefgebied voor een soort weer zonder te beoordelen of de soort daadwerkelijk voorkomt.

\section{B1.1.2 Afbakeningen tot beleidsrelevante indicatoren}

Het model beperkt zich tot landnatuur voor de soortgroepen vaatplanten, dagvlinders en broedvogels. Deze soorten zijn vaak de grootste soortgroepen in het Nederlandse natuurbeleid ${ }^{9}$ en zijn representatief voor de schaalniveaus landschap, vegetatiestructuur en standplaats (Carignan \& Villard, 2002) en bieden zodoende een betere afspiegeling van biodiversiteit dan wanneer één schaalniveau zou worden meegenomen (Wolters et al. 2006; Eglington et al. 2012). Daarnaast leggen provincies bij bepaling van natuurkwaliteit ook de nadruk op planten, vlinders en broedvogels (Van Beek et al. 2014).

\section{B1.1.3 Afbakeningen m.b.t. domein}

Het model gebruikt invoerbestanden met een resolutie van $25 \times 25$ meter. Daarbij is het mogelijk dat er verschillende vegetatietypes binnen één cel aanwezig zijn. Met name voor het modelleren van vaatplanten is deze resolutie nodig; het voorkomen van deze soortgroep wordt bepaald door de condities op standplaatsniveau. Een fijner schaalniveau is niet mogelijk, omdat de ruimtelijke informatie voor vegetaties niet op dit niveau beschikbaar is. Wanneer het schaalniveau grover zou worden, zou dit met name voor de voorspelling van vaatplanten ongunstig zijn.

De MNP is ontwikkeld voor het analyseren van soortgroepen op landelijk en provinciaal niveau. Het model is niet geschikt voor analyses op een lager schaalniveau, zoals op gebiedsniveau of voor analyses van individuele soorten. De resolutie van het instrument en de kwaliteit van de invoerdata zijn hiervoor niet hoog genoeg. Denk bijvoorbeeld aan onzekerheden over het grondwaterpeil. Daarnaast wordt voor de beoordeling gebruikgemaakt van drempelwaarden met betrekking tot duurzaam voorkomen die gericht zijn op het landelijke schaalniveau. Voor analyses op provinciaal niveau liggen dan ook nationale analyses ten grondslag. Wanneer analyses op een hoger schaalniveau (Europees) gedaan worden, zouden andere drempelwaarden gebruikt moeten worden.

Het model analyseert het landschap als een 'steady state'. Bij analyses van toekomstige situaties wordt verondersteld dat de doorgerekende interventies hun volledige effect hebben bereikt. Het model houdt daarbij geen rekening met geleidelijke effecten die optreden.

\footnotetext{
9 Zowel in de nieuwe Beheertypensystematiek als in de Vogel- en Habitatrichtlijn (inclusief typische soorten) behoren veel soorten tot de groepen vaatplanten, dagvlinders en broedvogels.
} 


\section{Bijlage 2 Korte beschrijving van invoerbestanden die gebruikt zijn bij de analyses van de Evaluatie Natuurpact}

De MNP 4.0 maakt gebruik van vier invoerbestanden. Van deze bestanden is alleen het bestand met stikstofdepositie (Ndep) vergelijkbaar met het bestand dat ook in de MetaNatuurplanner 2.0 is gebruikt. De bestanden met pH en GVG zijn specifiek voor de MNP ontwikkeld. Daarnaast wordt in de MNP 4.0 gebruikgemaakt van de Beheertypen. Voor de huidige situatie wordt daarbij gebruikgemaakt van de Beheertypenkaart en voor de toekomstige situatie voor de Ambitietypenkaart. Beide bestanden zijn een samenvoeging van provinciale bestanden met de ligging van de verschillende Beheertypen. Ten behoeve van de MNP zijn deze bestanden verfijnd (neergeschaald), waardoor meer typen onderscheiden worden. Dit is nodig om het leefgebied van soorten beter te kunnen modelleren. De verschillende bestanden worden kort toegelicht. Voor meer details wordt verwezen naar Van der Hoek et al. (in prep.).

\section{B2.1 Neergeschaalde Beheertypenkaart en Ambitietypenkaart}

In de Beheertypen- en Ambitietypenkaart komen (grootschalige) typen voor met onvoldoende detail voor de MNP 4.0. Hierdoor is het moeilijk om op een adequate manier aan te geven welke delen in het Natuur Netwerk Nederland (NNN) geschikt zijn als leefgebied voor soorten. Met behulp van diverse aanvullende ruimtelijke bestanden en een set aan beslisregels is het mogelijk deze typen te verfijnen. Deze neerschaling is in twee stappen uitgevoerd:

- Verfijning van grootschalige typen naar kleinschaliger typen binnen de bestaande typologie;

- Verdere verfijning van de duin- en moerastypen. Hiervoor hebben we de bestaande typologie uitgebreid met een aantal (sub)typen die voor de MNP relevant zijn

De neergeschaalde Beheertypen- en Ambitietypenkaart geven beide voor elk type in een $25 \times 25$ meter grid het oppervlakte aan het betreffende type. In één cel kunnen meerdere typen voorkomen.

\section{B2.2 Stikstofdepositie}

Voor de milieuconditie stikstof is de hoogte van de stikstofdepositie gebruikt. Hiervoor is een landsdekkende kaart beschikbaar (RIVM 2015). Dit betreft de feitelijke situatie in 2014.

\section{B2.3 $\mathrm{pH}$}

Voor de $\mathrm{pH}$ wordt een bestand met de bodem $\mathrm{pH}$ gebruikt. Dit bestand is een verbeterde versie van het bestand dat in 2015 is ontwikkeld (Wamelink et al. 2015). Voor alle natuurgebieden in de NNN is de $\mathrm{pH}$ bepaald op basis van vegetatieopnamen, bodemtypen en de neergeschaalde Beheertypenkaart. Voor meer details wordt verwezen naar Wamelink et al. (in prep.). 


\section{B2.4 GVG}

De GVG-MNP ${ }^{10}$ kaart is een samenvoeging van twee bestanden. Het eerste bestand is op een vergelijkbare wijze bepaald als de $\mathrm{pH}-\mathrm{kaart}$. Er is daarbij gebruikgemaakt van peilbuisgegevens. Het tweede bestand betreft de GVG-kaart die ontwikkeld is door Van Delft et al. (2017). Dit bestand is ruimtelijk minder dekkend voor natuurgebieden. Waar beide bestanden een waarde hebben, is deze gemiddeld om de uiteindelijk huidige situatie te bepalen.

Voor een gedetailleerdere beschrijving van beide bestanden wordt voor de GVG verwezen naar Van Delft et al. (2017).

\section{B2.5 Overzicht invoerbestanden per scenario's}

Naast de huidige situatie, planpotentieel en uitvoeringspotentieel zijn enkele alternatieven doorgerekend voor het planpotentieel. Deze alternatieven maken o.a. gebruik van zogenaamde optimale condities. De bestanden voor deze optimale condities zijn opgesteld door voor het dominant aanwezige beheertype na te gaan bij welke waarde voor GVG, stikstofdepositie en bodem $\mathrm{pH}$ de meeste soorten optimaal leefgebied hebben. In Tabel B2.1 wordt een overzicht gegeven van de invoerbestanden voor de verschillende scenario's en alternatieven van het planpotentieel.

Tabel B2.1 Overzicht van de gebruikte invoerbestanden voor de verschilleden scenario's en alternatieven voor het planpotentieel. In de tweede kolom staat BT voor Beheertypenkaart en AT voor Ambitietypenkaart. In de derde kolom verwijst GVG-MNP naar het specifieke bestand met de GVG dat voor de analyses met de MNP is ontwikkeld. In de derde tot en met vijfde kolom betreft de toevoeging 'opt' de bestanden waarbij de waarde in het bestand optimaal is voor het dominante beheertype in de neergeschaalde AT-kaart. In de vierde kolom verwijzen de jaartallen naar het jaartal van de betreffende depositiekaart dat als basis is genomen.

\begin{tabular}{lllll} 
Scenario & Beheertypen & GVG & Ndep \\
1 Huidig & Neergeschaalde BT-kaart & GVG-MNP & Ndep 2014 & pH \\
\hline 2 Planpotentieel (PP) & Neergeschaalde AT-kaart & GVG-PP & Ndep 2030-PP & pH-PP \\
\hline 3 Uitvoeringspotentieel (UP) & Neergeschaalde AT-kaart-UP & GVG-UP & Ndep 2030-UP & pH-UP \\
\hline 2a PP met huidige condities & Neergeschaalde AT-kaart & GVG-MNP & Ndep 2014 & pH \\
\hline 2b PP met optimale condities voor alle factoren & Neergeschaalde AT-kaart & GVG-opt & Ndep-opt & pH-opt \\
\hline 2c PP met optimale condities voor verdroging & Neergeschaalde AT-kaart & GVG-opt & Ndep 2030-PP & pHh-PP \\
\hline 2d PP met optimale condities voor vermesting & Neergeschaalde AT-kaart & GVG-PP & Ndep-opt & pH-PP \\
\hline 2e PP met optimale condities voor verzuring & Neergeschaalde AT-kaart & GVG-PP & Ndep 2030-PP & pH-opt \\
\hline
\end{tabular}

\footnotetext{
${ }^{10}$ Aangezien dit bestand specifiek is voor het gebruik van de MNP is aan de naam de toevoeging '-MNP' gegeven.
} 


\section{Bijlage 3 Resultaten expertmeetings}

\section{B3.1 Aangewezen gebieden}

Bij de $1^{\mathrm{e}}$ expertmeeting hebben de verschillende deskundigen van de provincie Gelderland ongeveer 30 gebieden aangewezen waar additionele maatregelen zullen bijdragen aan een grotere biodiversiteit in de provincie (Figuur B3.1).

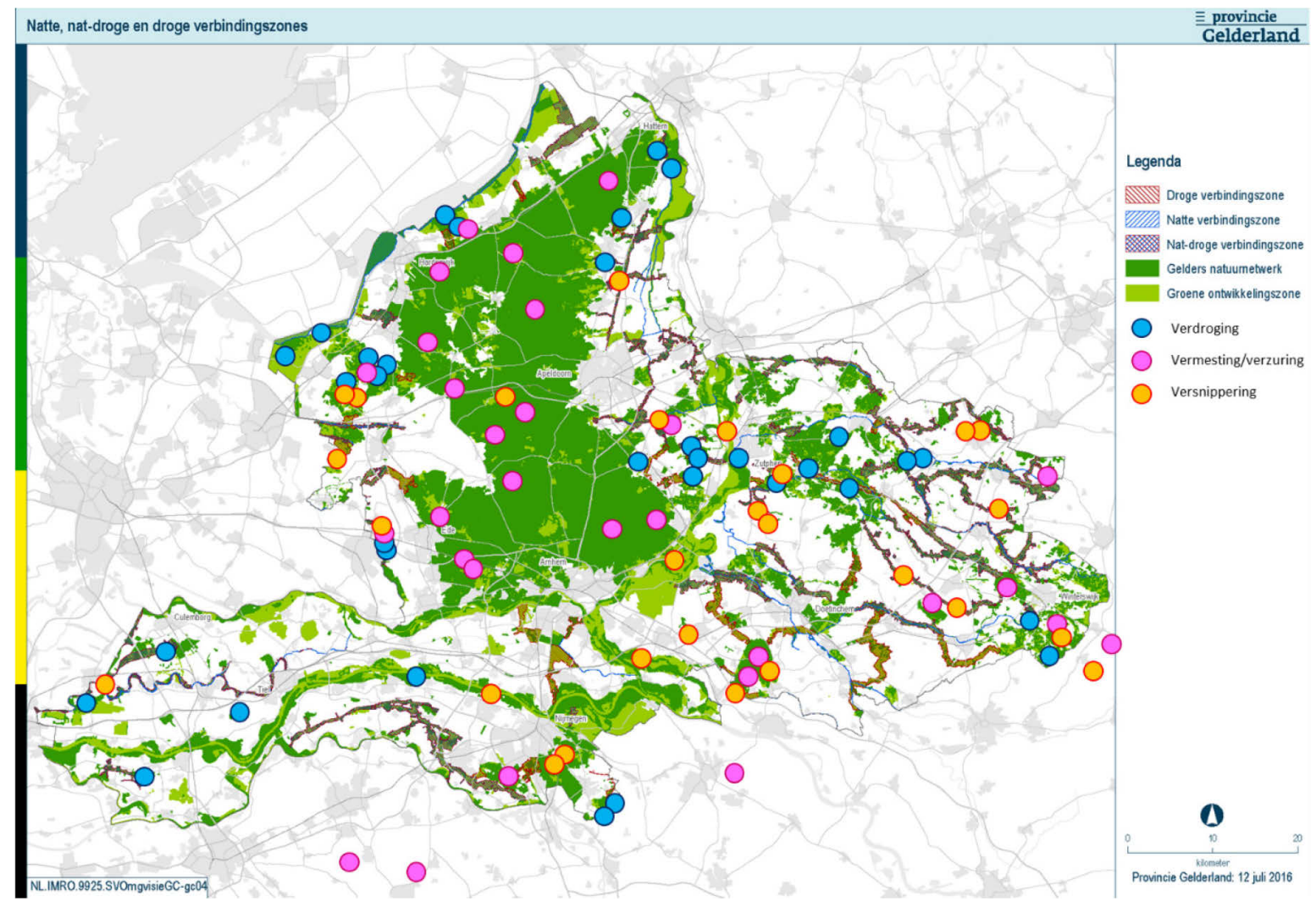

Figuur B3.1 Overzicht van de stickers die bij eerste expertmeeting zijn geplakt op de kaart van Gelderland.

- Arkenheem: N.a.v. de discussie is de inschatting dat hier na het uitvoeren van de geplande maatregelen geen probleem meer is m.b.t. verdroging. De analyses van de MNP van de scenario's Planpotentieel en Planpotentieel met optimale GVG ondersteunt deze inschatting. Er lijkt nauwelijks biodiversiteitswinst te behalen door verdrogingsproblemen verder op te lossen.

- Baakse beek: Hier zal ook ontsnippering van het watersysteem belangrijk zijn.

- Binnenveld: Uit de analyses met de MNP blijkt het gebied robuust genoeg voor de typen die in het natte graslanden die in het gebied voorkomen. Het ligt echter ingebed in een intensief gebruikt landschap, waardoor landschapsecologische processen op een grotere schaal (grondwaterstromen) mogelijk een probleem kunnen vormen.

- Bruuk: Dit betreft met name kwelproblemen, wat niet meegenomen wordt in de MNP.

- Linge(dijk): Ten behoeve van recreatie zijn daar gebieden opgehoogd. Eigenlijk is het streefpeilenplan op orde, maar kunnen enkele graslandtypen verdroogd zijn vanwege de opgehoogde gebieden.

- Rivierengebied: Dit betreft met name kwel, wat niet meegenomen wordt in de MNP. 
- Uiterwaarden/Gelderse Poort Moerassen: De Gelderse Poort is voor veel typen groot genoeg voor het herbergen van stabiele populaties. Toch zijn de moerassen in de uiterwaarden door de experts bij het thema versnippering besproken. Het idee is dat er goede potenties liggen om moerassen van de uiterwaarden beter met elkaar te verbinden. Onder andere door ook de potenties van beekmondingen in de rivieren beter te gebruiken.

- Veluwe: De huidige bestanden brengen de echte problematiek rond verzuring niet goed in beeld. Momenteel worden problemen steeds duidelijker zichtbaar van het langzaam uitspoelen van mineralen op de zandgronden in Gelderland. Hierdoor ontstaan problemen in het voedselweb die via bodem, planten, insecten naar vogels loopt (Van de Burg et al. (2017)). Deze problemen vragen naast mitigerende maatregelen ook om structurele oplossingen. Met betrekking tot versnippering is de Veluwe het grootste aaneengesloten terrestrische natuurgebied van Nederland. De versnippering betreft dan ook interne versnippering van open vegetaties.

Bij de $2^{\mathrm{e}}$ expertmeeting hebben de verschillende deskundigen uit Gelderland ruim 20 gebieden aangewezen waar additionele maatregelen zullen bijdragen aan een grotere biodiversiteit in de provincie (Figuur B3.2). Daar waar in de $1^{\mathrm{e}}$ expertmeeting alleen gebieden binnen het NNN zijn aangewezen, zijn in de $2^{\mathrm{e}}$ expertmeeting ook gebieden buiten het NNN aangewezen. De reden hiervoor was tweeledig: 1) buiten de NNN is in potentie mogelijk de meeste biodiversiteitswinst te realiseren en 2) oorzaken van problemen liggen vaak buit het NNN. Zo zijn bijvoorbeeld de Gelderse Vallei en de landbouwenclave bij Uddel en Elspeet als gebieden aangewezen. Ondanks dat PASmaatregelen problemen in Natura 2000-gebieden zullen mitigeren, is de verwachting dat de problemen rond vermesting voor de droge vegetatietypen niet volledig opgelost zullen worden.

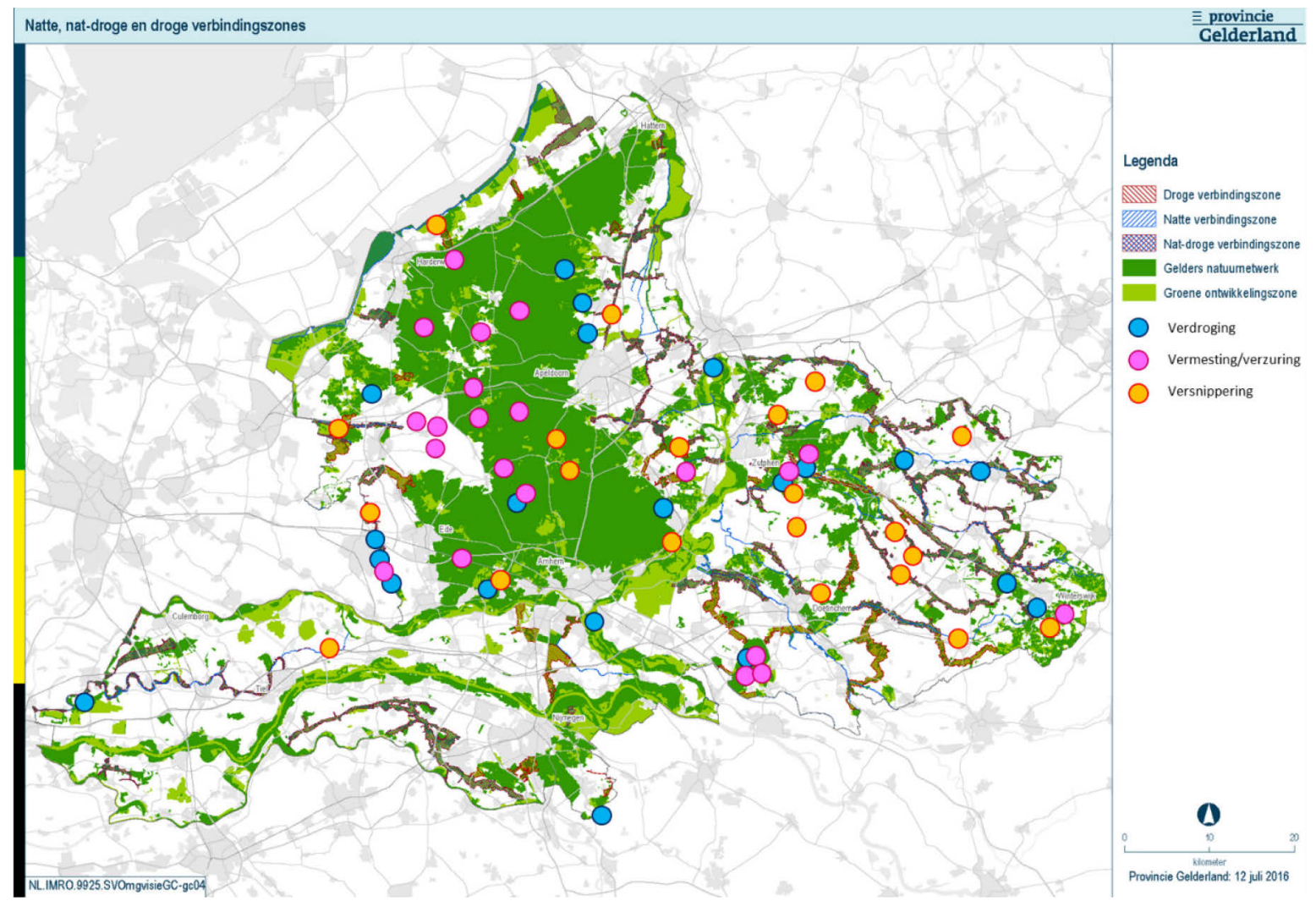

Figuur B3.2 Overzicht van de stickers die bij tweede expertmeeting zijn geplakt op de kaart van Gelderland.

- Binnenveld: Ook door de deskundigen uit de provincie wordt het Binnenveld genoemd bij versnippering, verdroging en vermesting. Momenteel is het als het ware een natuurgebied dat aan het infuus ligt. Maar fundamentele maatregelen zullen nodig zijn als dit gebied op zichzelf staand wil gaan functioneren. 
- Veluwe: Naast de interne versnippering van open natuurtypen is ook de versnippering door infrastructuur genoemd. Daarbij spelen tevens aspecten als het opwaarderen van fietsroutes, die o.a. Hazelwormen beïnvloeden in hun bewegingspatronen.

Op basis van de stickers zijn 22 gebieden benoemd (zie Figuur 5). Van deze gebieden zijn het Binnenveld en Winterswijk e.o. door beide groepen deskundigen genoemd in de drie thema's (Tabel B3.1).

Tabel B3.1 Overzicht van de stickers voor de 22 gebieden die verder uitgewerkt zijn (Figuur 5).

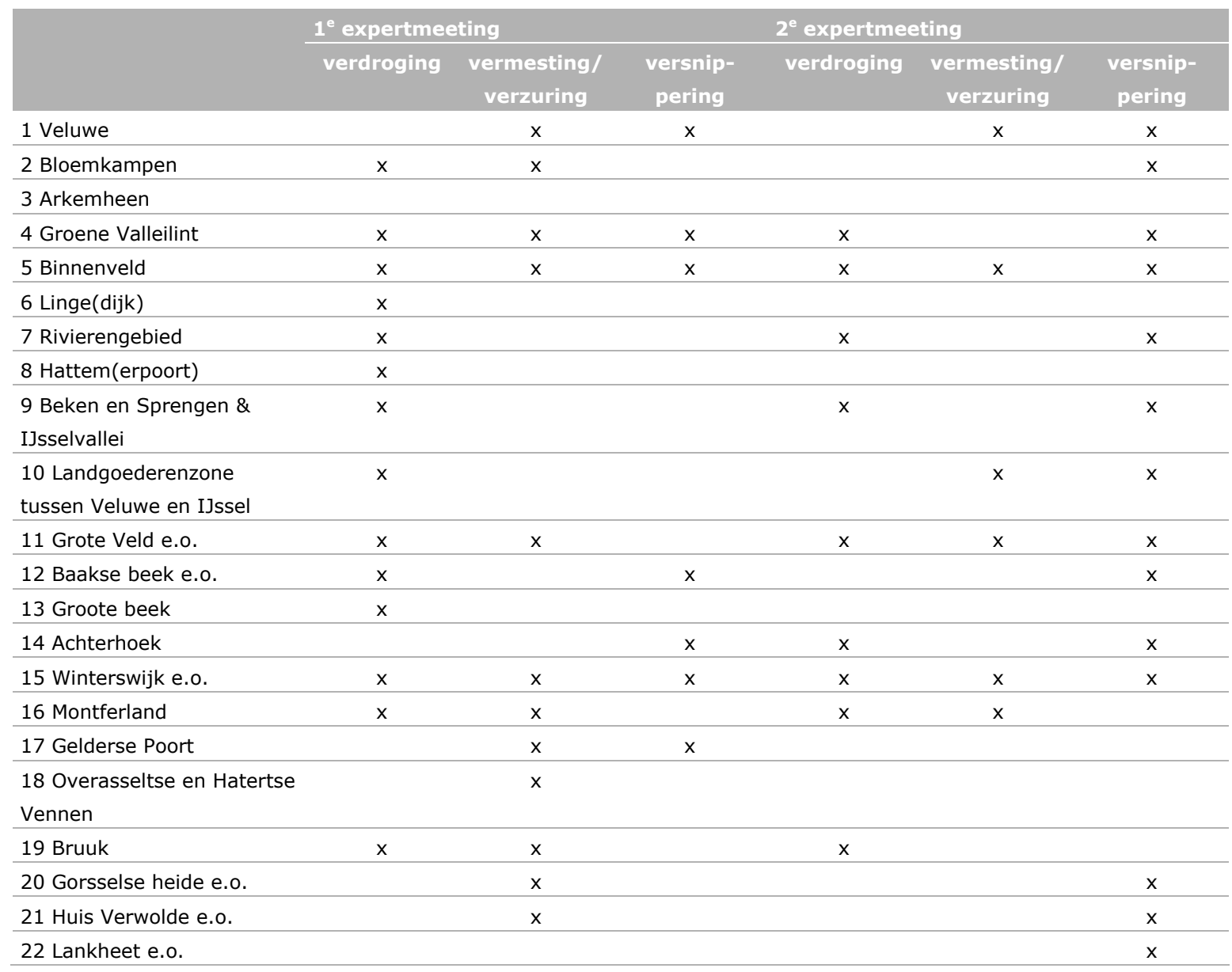

\section{B3.2 Algemene opmerkingen met betrekking tot natuurbeleid in provincie Gelderland}

Gedurende de discussies per thema zijn ook enkele opmerkingen gemaakt die niet zo zeer aan één of enkele locaties toe te wijzen zijn, of die betrekking hebben op de gebruikte gegevens, of die betrekking hebben op meer algemene zaken rond natuurbeleid.

Bij de eerste expertmeeting zijn de volgende opmerkingen gemaakt:

- Verdroging Veluwe: modelresultaten voor verdroging zijn voor de Veluwe minder geschikt wanneer gebruikmaakt wordt van de gemiddelde voorjaarsgrondwaterstand (GVG). Zeker voor situaties waarbij de grondwaterstand lager is dan 3 meter onder maaiveld. De Veluwe kent 
schijngrondwaterstanden waardoor condities geschikt kunnen zijn voor natte typen natuur ${ }^{11}$, terwijl de kaarten aangeven dat de grondwaterstand erg laag is.

- $\mathrm{pH}$-problemen op (hogere) zandgronden: het afgelopen jaar is het thema verzuring weer belangrijker geworden. Het blijkt dat op mineraalarme bodems het beschikbare calcium zo laag is geworden door de constante depositie van ammonium dat dit leidt tot problemen voor o.a. vogels ${ }^{12}$. De problemen rond verzuring dienen opnieuw op de politieke agenda te komen en een strategische aanpak is nodig om het tekort aan basische mineralen ${ }^{13}$ weer op peil te krijgen.

- Depositie: de depositie lijkt een structureel probleem te zijn. Zeker in het licht van verzuring. Men kan maatregelen nemen om verzuring tegen te gaan, maar tegelijkertijd zal men ook de oorzaak moeten aanpakken. De inschatting is dat de PAS-maatregelen voor de droge systemen onvoldoende oplossingen biedt.

- Ambitietypenkaart: door het gebruik van de resultaten van de Evaluatie Natuurpact wordt duidelijk dat de Ambitiekaart erg sturend kan zijn met betrekking tot waar nog knelpunten met biodiversiteit verwacht kunnen worden in de toekomst. In sommige gevallen geven de deskundigen aan dat ambities mogelijk te laag zijn en in sommige gevallen mogelijk te hoog. Met betrekking tot lage ambities wordt met name het rivierengebied genoemd en met betrekking tot te hoge ambities de kleine natuurgebieden in de Achterhoek:

- Rivierengebied: de deskundigen van de provincie vinden dat sommige gebieden zich goed lenen voor hogere ambities. Momenteel zijn daar de condities voor moerasnatuur aanwezig en dat zou dan ook nagestreefd kunnen worden door bijv. beter ingerichte beekmondingen.

- Achterhoek: veel natuurgebieden in de Achterhoek zijn erg klein en liggen geïsoleerd. Het lijkt daarom moeilijk om bijvoorbeeld gezonde bosecosystemen na te streven in deze gebieden. Het is mogelijk beter om landschappelijke natuur na te streven met leefgebieden voor soorten die van halfopen landschappen houden. Eventueel geplande verbindingszones zullen ook bijdragen aan het creëren van dit type landschappen.

- Klimaatverandering: bij het bepalen van de huidige gebieden wordt geen rekening gehouden met de mogelijk consequenties van klimaatverandering. De exacte impact op natuur is moeilijk te voorspellen, maar de inschatting is dat klimaatverandering de impact van versnippering en verdroging gaat versterken en dat de huidige soortensamenstelling in ecosystemen zal veranderen. Ten behoeve van adaptatie zijn grotere gebieden en robuuste corridors nodig ${ }^{14}$. Voor de natte ecosystemen zouden rivieren van nature als corridor werken, maar voor de droge ecosystemen zouden ze een natuurlijke barrière kunnen zijn.

- Versnipperde ecosystemen; In Gelderland is de impact van versnippering verschillend voor verschillende ecosystemen.

- Natte ecosystemen: het rivierengebied kan in potentie als natuurlijke corridor voor natte natuurgebieden functioneren. Momenteel kent Gelderland al enkele grote moerasgebieden die met name in het zuidoosten goed verbonden zijn. Deze natte ecosystemen kunnen ook richting de IJssel verbonden worden, waarbij met name het gebied rond Arnhem een knelpunt is.

- Bosecosysteem: met betrekking tot het bosecosysteem heeft Gelderland met de Veluwe het grootste bosgebied van Nederland. De laatste jaren is geïnvesteerd om versnippering van bosgebieden op de Veluwe tegen te gaan door rasters doorlaatbaar te maken en door het aanleggen van ecoducten over snelwegen en spoorwegen. Naast de Veluwe kent Gelderland nog enkele grote kernen met bos: Montferland, Stuwwal Nijmegen en Grote Veld. Deze gebieden kunnen verbonden worden met de Veluwe of bosgebieden in omringende provincies of Duitsland. Naast deze kernen kent de provincie vele kleine bosgebieden in de Achterhoek. Deze gebieden zijn dusdanig klein en geïsoleerd dat een natuurlijk bossysteem moeilijk te realiseren is in de aparte gebieden. Toch kunnen kleine bosgebieden een bijdrage leveren aan de biodiversiteit in Gelderland, met name voor de soorten die van halfopen landschappen houden. Ook kunnen de gebieden functioneren als stapstenen tussen de eerdergenoemde boskernen.

- Heide en hoogveen: op de Veluwe liggen enkele grote kernen met heide. Deze terreinen liggen vaak geïsoleerd midden in het bosgebied. Nagegaan moet worden waar door omvorming betere

\footnotetext{
${ }^{11}$ Zie ook "Bijlage ontwerp Beheerplan Natura 2000057 - Veluwe" voor de typen H4010A en H7150 (https://www.gelderland.nl/bestanden/Documenten/Gelderland/03Natuur-enmilieu/161028 Beheerplan_N2000_Veluwe bijlagen.pdf).

12 Zie Van den Burg 2017: https://vakbladnbl.nl/wp-content/uploads/VNBL_juni2017_koolmezen.pdf

${ }^{13}$ Met name Calcium, maar ook andere mineralen zijn van belang voor een gezond ecosysteem.

${ }^{14}$ Zie bijvoorbeeld: http://edepot.wur.nl/318910.
} 
samenhang van de heideterreinen gerealiseerd kan worden. Gelderland heeft één groot veengebied, Korenburgerveen, en een grensoverschrijdend gebied, Wooldse veen. Zoals de meeste veengebieden in Nederland liggen ze geïsoleerd tussen agrarisch landschap. Op een hoger schaalniveau vormen de veengebieden als het ware kralen aan een ketting met gebieden als Zwilbrockerveen en Haaksbergerveen.

- Aquatisch/beekdalen: beekdalen kennen hun eigen problematiek rond versnippering. Naast waterkwaliteit en morfologie spelen ook stuwen en dammen een grote rol voor het realiseren van biodiversiteitswaarden in beken. Binnen de expertmeetings is hier niet op ingegaan. Voor aquatische ecosystemen zal apart expertise worden ingewonnen.

- Prioriteit bepalen: voor het bepalen van de prioriteit waar additionele maatregelen nodig zijn, adviseren de deskundigen van de provincie Gelderland om rekening te houden met andere facetten die spelen in het gebied, zoals de beheercyclus, houtwinning en drinkwatervoorzieningen.

- Lokale kernen: in regio's als Groene Lintvallei en Winterswijk e.o. is relatief veel natuur aanwezig. Toch laten de analyses zien dat hier veel winst te halen is door verdrogings-, vermestings- en versnipperingsproblemen op te lossen. De deskundigen zien hier oplossingen door lokale kernen te realiseren die stabiliserend kunnen functioneren voor de overige natuurgebieden.

- Aquatische natuur: om de prioriteiten van de aquatische natuur te bepalen, zal advies worden ingewonnen bij andere deskundigen.

Bij de $2^{\mathrm{e}}$ expertmeeting zijn de volgende aanvullende opmerkingen gemaakt:

- Biodiversiteitswinst buiten NNN: meerdere deskundigen uit de provincie dragen aan dat momenteel erg veel aandacht naar het NNN gaat als men het heeft over behoud en herstel van de biodiversiteit in de provincie Gelderland. Dit terwijl ze van mening zijn dat er ook veel en mogelijk nog meer biodiversiteitswinst te halen is in het agrarisch gebied. Naast algemene biodiversiteitswinst is daar ook winst te halen voor sommige soorten van de Vogel- en Habitatrichtlijn. Dit punt is meerdere keren teruggekomen in de discussies rond de verschillende thema's.

- Ambities: ook de deskundigen uit de provincie geven aan dat uitwisseling van minder waardevolle natuurgebieden met potentieel belangrijke gebieden tot biodiversiteitswinst kan leiden. Hierbij moet men wel voorzichtig zijn dat algemene biodiversiteit opgeofferd wordt voor zeldzame biodiversiteit. Zowel algemene soorten als zeldzame soorten zouden moeten profiteren van een dergelijke uitwisseling.

- Depositie: dit probleem komt voor een groot deel van buiten de provincie, maar ook binnen de provincie is dit probleem deels op te lossen. Daarbij worden niet alleen de technische oplossingen (zoals luchtwassers) genoemd, maar ook de handhaving of deze technische oplossingen daadwerkelijke functioneren (worden ze geplaatst en worden ze ook gebruikt). Met name lokaal kan deze handhaving leiden tot een verlaging van de depositie op kwetsbare natuurgebieden.

- Bedrijfsvoering aanpassen aan het landschap: een van de oplossingen voor veel problemen in het agrarische gebied die door de deskundigen is aangedragen, is om de bedrijfsvoering aan te passen aan het landschap. Momenteel lijkt het er eerder op dat het landschap aangepast wordt aan de bedrijfsvoering. Een voorbeeld is meer natte landbouw, zoals het kweken van lisdodden voor isolatiemateriaal. Momenteel is dit niet mogelijk, omdat fabrieken die dit materiaal verwerken niet in Nederland staan.

- Waterwinning en verdroging: om de verdrogingsproblemen in sommige gebieden op te lossen, moet samenwerking gezocht worden met waterwinning. De deskundigen kennen met name situaties op de Veluwe, maar dit speelt mogelijk op meerdere locaties.

- Verzuring en bosbeheer: om de verzuring in bossen tegen te gaan, worden twee oplossingen aangedragen: kiezen voor bossoorten die mineralisatie in de bodem bevorderen en het laten staan/liggen van dood hout en afvalhout bij de oogst. Met betrekking tot het laatste wordt aangegeven dat dit type beheer reeds in de meeste gebieden wordt uitgevoerd.

- Klimaatverandering: ook de deskundigen uit de provincie dragen klimaatverandering aan als factor waar voor het komende natuurbeleid rekening mee gehouden moet worden. Naast te verwachten problemen die gemitigeerd/geadapteerd moeten worden, kunnen maatregelen die tegen het klimaat genomen gaan worden vanuit andere sectoren ook bijdragen aan de biodiversiteit van de provincie Gelderland. 
- Versnippering:

- Ontsnipperende maatregelen op maat: om het functioneren van zowel EVZ's als faunapassages te verbeteren, moet de inrichting beter afstemmen op de soorten die in het landschap gebruik moeten maken van de maatregelen.

- Met name op de Veluwe spelen versnipperingsproblemen met infrastructuur. Er lopen veel wegen en enkele spoorwegen door dit grote gebied, waardoor voor sommige soorten eigenlijk kleinere deelgebieden ontstaan. Oplossingen liggen in het verkeersluw maken van wegen, maximale snelheid aanpassen of het aanleggen van faunapassages. Ook op een kleinere schaal spelen bijvoorbeeld betonnen fietspaden een rol voor sommige amfibieën, reptielen en insecten.

- De deskundigen van de provincie verwachten dat de hoogste prioriteit met betrekking tot herstel van landschapselementen ligt bij Winterswijk e.o. en Graafschap.

- Benutten bermen: in Gelderland is een mooi voorbeeld waarbij natuurlijk bermbeheer wordt nagestreefd: gemeente Berkelland heeft bermen teruggenomen in beheer. Dit heeft nieuwe natuur opgeleverd en zijn met name kleinschalige landschapselementen hersteld voor soorten in het besloten agrarische gebied. De afgelopen jaren blijken deze bermen vaak bij percelen getrokken te zijn, waardoor deze kleine landschapselementen langzaam zijn verdwenen. De inschatting is dat dit in meerdere gemeenten tot biodiversiteitswinst kan leiden.

- Recreatie: de deskundigen uit de provincie dragen aan dat recreatie voor met name de Veluwe een steeds groter probleem wordt bij het behoud van met name vogelsoorten. Vooral voor soorten van open vegetatietypen kan verstoring aanzienlijke problemen opleveren. Het geplande zoneringsplan wordt belangrijker wil men de natuurwaarden op lage termijn kunnen behouden in gebieden als de Veluwe.

- Gezondheid: gezondheid is een thema dat erg belangrijk aan het worden is in het beleid. Groen en natuurgebieden zijn belangrijk voor een goede gezondheid. De deskundigen verwachten dat het beter lijkt om mee te liften op het thema gezondheid dan op thema's die alleen op natuur gericht zijn om nieuwe natuurgebieden te realiseren.

- Vermesting watersystemen: vermesting speelt niet alleen een rol bij het herstel en behoud van terrestrische biodiversiteit, maar ook voor aquatische biodiversiteit. De problematiek is echter anders i.v.m. het anders functioneren van watersystemen dan terrestrische systemen.

- Achteruitgang insecten: de deskundigen uit de provincie geven ook specifiek aandacht aan de achteruitgang van insecten. Recent onderzoek uit Duitsland laat grote achteruitgangen zien de laatste decennia en ook experts uit Groot-Brittannië, België en Nederland geven aan dat insecten als motten, bijen, hommels en zweefvliegen sterk achteruit zijn gegaan. Wat de oorzaak is en waar de oplossing gezocht moet worden, is nog niet duidelijk. De belangrijkste oorzaken lijken een combinatie te zijn van verlies van leefgebied, klimaatverandering, intensivering landbouw en gebruik van nieuwe bestrijdingsmiddelen als neonicotinoïden. 
Wageningen Environmental Research Postbus 47

6700 AA Wageningen

T 0317480700

www.wur.nl/environmental-research

Wageningen Environmental Research Rapport 2847

ISSN 1566-7197
De missie van Wageningen University \& Research is 'To explore the potential of nature to improve the quality of life'. Binnen Wageningen University \& Research bundelen Wageningen University en gespecialiseerde onderzoeksinstituten van Stichting Wageningen Research hun krachten om bij te dragen aan de oplossing van belangrijke vragen in het domein van gezonde voeding en leefomgeving. Met ongeveer 30 vestigingen, 5.000 medewerkers en 10.000 studenten behoort Wageningen University \& Research wereldwijd tot de aansprekende kennisinstellingen binnen haar domein. De integrale benadering van de vraagstukken en de samenwerking tussen verschillende disciplines vormen het hart van de unieke Wageningen aanpak. 



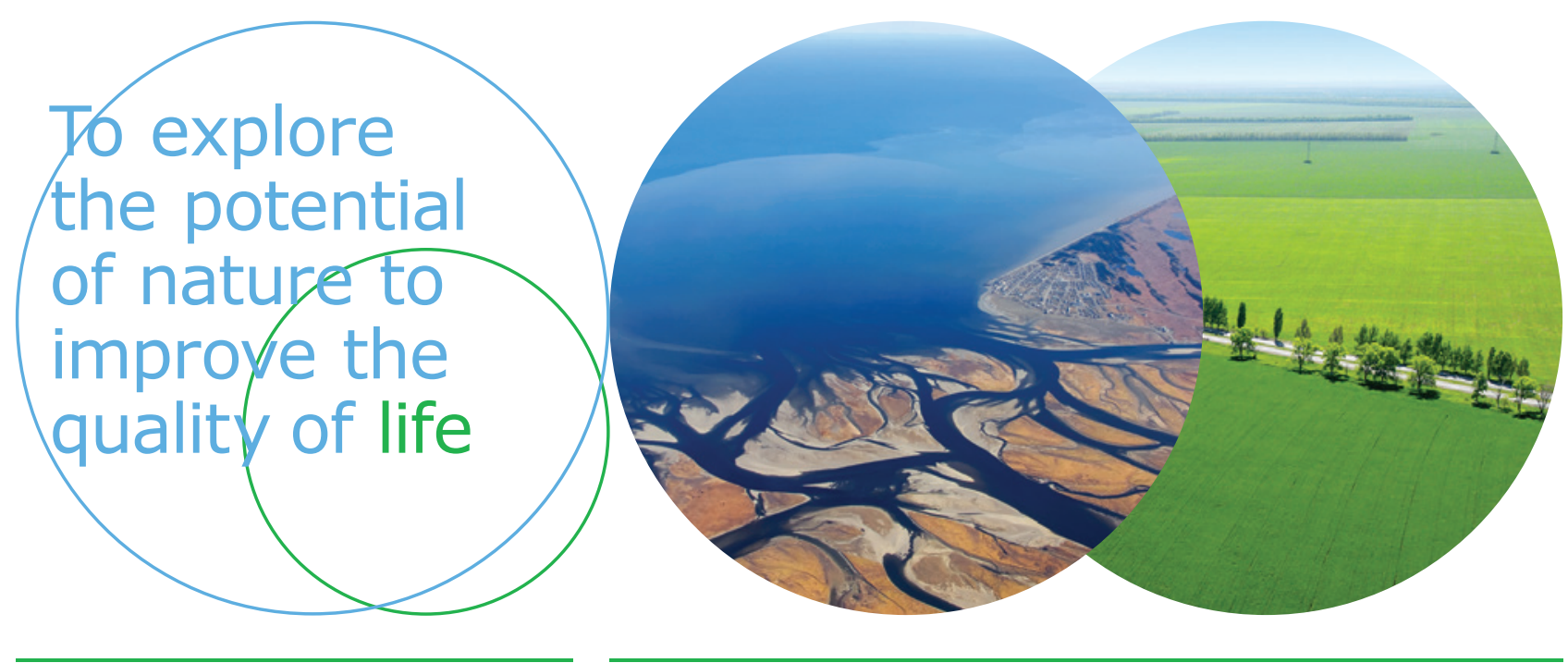

Wageningen Environmental Research Postbus 47

$6700 \mathrm{AB}$ Wageningen

T 317480700

www.wur.nl/environmental-research

Rapport 2847

ISSN 1566-7197
De missie van Wageningen University \& Research is 'To explore the potential of nature to improve the quality of life'. Binnen Wageningen University \& Research bundelen Wageningen University en gespecialiseerde onderzoeksinstituten van Stichting Wageningen Research hun krachten om bij te dragen aan de oplossing van belangrijke vragen in het domein van gezonde voeding en leefomgeving. Met ongeveer 30 vestigingen, 5.000 medewerkers en 10.000 studenten behoort Wageningen University \& Research wereldwijd tot de aansprekende kennisinstellingen binnen haar domein. De integrale benadering van de vraagstukken en de samenwerking tussen verschillende disciplines vormen het hart van de unieke Wageningen aanpak. 